INSTITUTO DE PESQUISAS ENERGÉTICAS E NUCLEARES

Autarquia associada à Universidade de São Paulo

\title{
USO DA VOLTAMETRIA CÍCLICA E DA ESPECTROSCOPIA DE IMPEDÂNCIA ELETROQUÍMICA NA DETERMINAÇÃO DA ÁREA SUPERFICIAL ATIVA DE ELETRODOS MODIFICADOS À BASE DE CARBONO
}

\section{LETICIA LOPES DE SOUZA}

Dissertação apresentada como parte dos requisitos para obtenção do Grau de Mestre em Ciências na Área de Tecnologia Nuclear - Materiais

Orientadora:

Profa. Dra. Christina Aparecida Leão

Guedes de Oliveira Forbicini

SÃO PAULO 
A meus pais, Ivete e Hermínio, por todo amor, respeito e confiança

Ao meu irmão, Eduardo, pela amizade e por todo apoio nos momentos mais difíceis 


\section{AGRADECIMENTOS ESPECIAIS}

Agradeço:

à Dra. Christina Aparecida Leão Guedes de Oliveira Forbicini, pela

orientação, apoio, compreensão e paciência na orientação deste trabalho

e

à minha família e amigos, pelo apoio e incentivo. 


\section{AGRADECIMENTOS}

Agradeço:

Ao Prof. Dr. Almir Oliveira Neto do Centro de Células a Combustível de Hidrogênio $(\mathrm{CCCH})$ por colocar a disposição o laboratório, pela contribuição no trabalho e pelas valiosas opiniões.

À Profa. Dra. Ivana Conte Cosentino do Centro de Ciência de Tecnologia dos Materiais (CCTM) pelas medidas de BET.

Aos colegas pela troca de conhecimento e pela amizade, em especial ao MSc. Maviael José da Silva que me ajudou constantemente na realização das medidas e no tratamento dos dados.

Aos membros do Seminário de Área pelas sugestões e discussões.

Aos meus amigos Alberto Lopes Pandeirada, Marcelo Souza da Silva, Shirley Leite dos Reis e Thais de Oliveira pelos momentos de alegria e amizade.

Ao CNPq, pelo apoio financeiro ao projeto.

E a todos que de alguma forma me ajudaram, cada um da sua maneira, sempre com a mesma importância, na realização deste trabalho. 
"Se o cotidiano Ihe parece pobre, não o acuse. Acuse a si mesmo por não ser sábio o bastante para extrair suas riquezas." 


\title{
USO DA VOLTAMETRIA CÍCLICA E DA ESPECTROSCOPIA DE IMPEDÂNCIA ELETROQUÍMICA NA DETERMINAÇÃO DA ÁREA SUPERFICIAL ATIVA DE ELETRODOS MODIFICADOS À BASE DE CARBONO
}

\author{
Letícia Lopes de Souza
}

\section{RESUMO}

Eletrodos à base de carbono, como os eletrodos de troca iônica, entre outros, têm aplicação principalmente no tratamento de efluentes industriais e rejeitos radioativos. Carbono é também amplamente utilizado em células a combustível como substrato para os eletrocatalisadores, por possuir elevada área superficial, que supera a sua área geométrica. $O$ conhecimento desta superfície ativa total é importante na determinação das condições de operação de uma célula eletroquímica no que diz respeito às correntes a serem aplicadas (densidade de corrente). No presente estudo foram utilizadas duas técnicas eletroquímicas na determinação da área superficial ativa de eletrodos de carbono vítreo e poroso e eletrodos de troca iônica: espectroscopia de impedância eletroquímica (EIE) e voltametria cíclica (VC). Os experimentos foram realizados com soluções de $\mathrm{KNO}_{3}$ 0,1 mol.L-1 em célula eletroquímica de três eletrodos: eletrodo de trabalho à base de carbono, eletrodo auxiliar de platina e eletrodo de referência de $\mathrm{Ag} / \mathrm{AgCl}$. Os eletrodos de carbono vítreo e de carbono poroso utilizado possuíam uma área geométrica de $3,14 \times 10^{-2} \mathrm{~cm}^{2}$ e $2,83 \times 10^{-1} \mathrm{~cm}^{2}$, respectivamente. $O$ eletrodo de troca iônica foi preparado misturando-se grafite, carbono, resina de troca iônica e um aglutinante, sendo esta mistura aplicada em três camadas sobre feltro de carbono, utilizando-se nos experimentos uma área geométrica de $1,0 \mathrm{~cm}^{2}$. Por EIE determinou-se diretamente a capacitância dos materiais dos eletrodos $\left(\mathrm{C}_{\mathrm{d}}\right)$ utilizando-se os diagramas de Bode. $\mathrm{O}$ valor de 172 $\mu \mathrm{F} . \mathrm{cm}^{-2}$ encontrado para o carbono vítreo está de acordo com a literatura ( 200 $\left.\mu \mathrm{F} . \mathrm{cm}^{-2}\right)$. Por VC, variando a velocidade de varredura de 0,2 a 2,0 mV.s $\mathrm{s}^{-1}$,

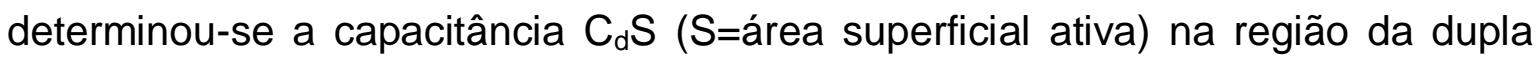
camada elétrica (DCE) para cada um dos materiais, Por EIE, foram determinados os valores de $C_{d}$ de $3,0 \times 10^{-5} \mu \mathrm{F} . \mathrm{cm}^{-2}$ e de $11,0 \times 10^{3} \mu \mathrm{F} . \mathrm{cm}^{-2}$ para os eletrodos de carbono poroso e de troca iônica, respectivamente, o que possibilitou a determinação das áreas superficiais ativas de $3,73 \times 10^{6} \mathrm{~cm}^{2}$ e $4,72 \mathrm{~cm}^{2}$. Portanto, o uso combinado das técnicas de EIE e VC mostra-se promissor para o cálculo das áreas superficiais ativas de eletrodos à base de carbono. 


\title{
USE OF CYCLIC VOLTAMMETRY AND ELECTROCHEMICAL IMPEDANCE SPECTROSCOPY FOR THE DETERMINATION OF ACTIVE SURFACE AREA OF MODIFIED CARBON-BASED ELECTRODES
}

\author{
Letícia Lopes de Souza
}

\begin{abstract}
Carbon-based electrodes as well the ion exchange electrodes among others have been applied mainly in the treatment of industrial effluents and radioactive wastes. Carbon is also used in fuel cells as substrate for the electrocatalysts, having high surface area which surpasses its geometric area. The knowledge of the total active area is important for the determination of operating conditions of an electrochemical cell with respect to the currents to be applied (current density). In this study it was used two techniques to determine the electrochemical active surface area of glassy carbon, electrodes and ion exchange electrodes: cyclic voltammetry (CV) and electrochemical impedance spectroscopy (EIS). The experiments were carried out with $\mathrm{KNO}_{3} 0.1$ mol. $\mathrm{L}^{-1}$ solutions in a threeelectrode electrochemical cell: carbon-based working electrode, platinum auxiliary electrode and $\mathrm{Ag} / \mathrm{AgCl}$ reference electrode. The glassy carbon and porous carbon electrodes with geometric areas of $3.14 \times 10^{-2}$ and $2.83 \times 10^{-1} \mathrm{~cm}^{2}$, respectively, were used. The ion exchange electrode was prepared by mixing graphite, carbon, ion exchange resin and a binder, and this mixture was applied in three layers on carbon felt, using a geometric area of $1.0 \mathrm{~cm}^{2}$ during the experiments. The capacitance $\left(\mathrm{C}_{\mathrm{d}}\right)$ of the materials was determined by EIS using Bode diagrams. The value of $172 \mu \mathrm{F} . \mathrm{cm}^{-2}$ found for the glassy carbon is consistent with the literature data $\left(\sim 200 \mu \mathrm{F} . \mathrm{cm}^{-2}\right)$. By VC, varying the scan rate from 0.2 to $2.0 \mathrm{mV} . \mathrm{s}^{-1}$, the capacitance $\mathrm{C}_{d} \mathrm{~S}(\mathrm{~S}=$ active surface area) in the region of the electric double layer (EDL) of each material was determined. By EIS, the values of $C_{d}, 3.0 \times 10^{-5}$ $\mu \mathrm{F} . \mathrm{cm}^{-2}$ and $11 \times 10^{3} \mu \mathrm{F} . \mathrm{cm}^{-2}$, were found for the porous carbon and ion exchange electrodes, respectively, which allowed the determination of active surface areas as $3.73 \times 10^{6} \mathrm{~cm}^{2}$ and $4.72 \mathrm{~cm}^{2}$. To sum up, the combined use of EIS and CV techniques is a valuable tool for the calculation of active surface areas of carbonbased electrodes.
\end{abstract}




\section{SUMÁRIO}

página

1 INTRODUÇÃO .1

2 OBJETIVO .5

3 REVISÃO BIBLIOGRÁFICA .6

Métodos utilizados na determinação de área superficial. 9

Porosimetria por Intrusão de Mercúrio. . .10

Normalização por carga de CO adsorvida na superfície dos eletrodos ...................11

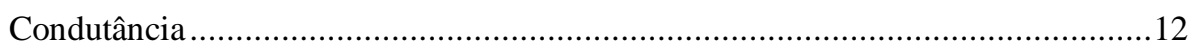
Impedância.

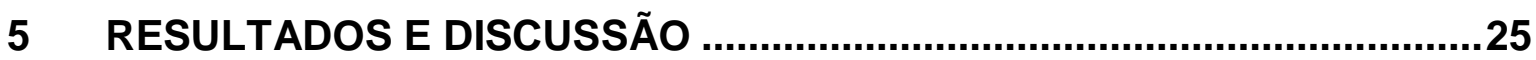


6 CONCLUSÃO

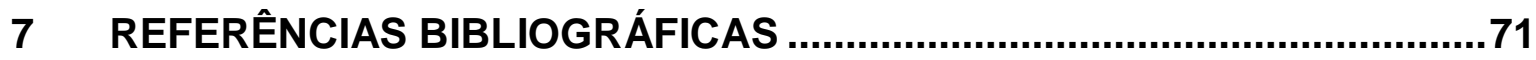




\section{LISTA DE FIGURAS}

FIGURA 1 - Representação esquemática da estrutura do Carbono Vítreo (CV).......18

FIGURA 2 - Eletrodo de Carbono Vítreo utilizado nos experimentos

FIGURA 3 - Eletrodo de Troca lônica (ETI) confeccionado variando as porcentagens em peso dos componentes

FIGURA 4 - Haste de Carbono Poroso envolta com Durepox ${ }^{\circledR}$ para delimitar a área superficial a ser analisada.

FIGURA 5 - Potenciostato/Galvanostato e célula eletrolítica utilizados nos experimentos de voltametria cíclica .23

FIGURA 6 - Esquema para a realização das medidas de impedância AC em sistemas eletroquímicos.

FIGURA 7 - Voltamograma cíclico do eletrodo de Carbono Vítreo, em solução de $\mathrm{KNO}_{3} \quad 0,1 \mathrm{~mol} . \mathrm{L}^{-1}$, velocidade de varredura variando de 0,2 a 2,0 mV.s ${ }^{-1}$, com ampliação da região da DCE. .26

FIGURA 8 - Corrente estacionária versus a velocidade de varredura para os potenciais de 0,5, 0,6 e 0,7 V(vs $\mathrm{Ag} / \mathrm{AgCl}$ ) e a regressão linear segundo a Eq.13 para o carbono vítreo.

FIGURA 9 - Representação de Bode para o Carbono Vítreo nos potenciais de 0,5, 0,6 e $0,7 \vee(v s \mathrm{Ag} / \mathrm{AgCl})$ .29

FIGURA 10 - Micrografias obtidas por Microscopia Eletrônica de Varredura (MEV) da superfície do eletrodo de Carbono Vítreo (ECV), a) 500x, b) 1000x...31 
FIGURA 11 - Voltamograma Cíclico do ETI-1 $\left(1 \mathrm{~cm}^{2}\right)$, em solução de $\mathrm{KNO}_{3}, 0,1$ mol. $\mathrm{L}^{-1}$, velocidade de varredura variando 0,2 a $2,0 \mathrm{mV} . \mathrm{s}^{-1}$, com ampliação da região de DCE.

FIGURA 12 - Corrente capacitiva em função da velocidade de varredura para os potenciais de 0,5 a $1,0 \mathrm{~V}$ (vs $\mathrm{Ag} / \mathrm{AgCl}$ ) em solução de $\mathrm{KNO}_{3}$ 0,1 mol.'${ }^{1}$, velocidade de varredura variando de 0,2 a $50 \mathrm{mV} . \mathrm{s}^{-1}$, para o ETI-1 (1 $\left.\mathrm{cm}^{2}\right)$.

FIGURA 13 - Corrente capacitiva estacionária em função da velocidade de varredura para os potenciais de $0,5,0,6$ e $0,7 \mathrm{~V}(\mathrm{vs} \mathrm{Ag} / \mathrm{AgCl})$ e a regressão linear segundo a Eq. 13, para o ETI-1 $\left(1 \mathrm{~cm}^{2}\right)$.

FIGURA 14 - Representação de Bode para ETI-1 no potencial de 0,5, 0,6 e 0,7 V (vs $\mathrm{Ag} / \mathrm{AgCl}$ ) em solução de $\mathrm{KNO}_{3}, 0,1 \mathrm{~mol} . \mathrm{L}^{-1}$..... 36

FIGURA 15 - Micrografias obtidas por Microscopia Eletrônica de Varredura (MEV) da superfície do ETI-1 com aumento de: a) 100x, b) 500x e c) $1000 x$ .38

FIGURA 16 - Voltamograma cíclico do $\operatorname{ETI}-1\left(3,1 \mathrm{~cm}^{2}\right)$, em solução de $\mathrm{KNO}_{3} 0,1$ mol. $\mathrm{L}^{-1}$, velocidade de varredura variando de 0,2 a $2,0 \mathrm{mV} . \mathrm{s}^{-1}$, com ampliação da região da DCE. .40

Figura 17 - Corrente estacionária em função da velocidade de varredura para o ETI$1\left(3,1 \mathrm{~cm}^{2}\right)$ nos potenciais de $0,5,0,6$ e $0,7 \mathrm{~V}(v s \mathrm{Ag} / \mathrm{AgCl})$ e os ajustes das curvas segundo a Eq.13. .41

Figura 18 - Representação de Bode para o $\operatorname{ETI}-1\left(3,1 \mathrm{~cm}^{2}\right)$ nos potenciais de 0,5, 0,6 e $0,7 \mathrm{~V}$ (vs $\mathrm{Ag} / \mathrm{AgCl})$

FIGURA 19 - Micrografias obtidas por Microscopia Eletrônica de Varredura (MEV) da superfície de ETI-2 com aumento de: a) 100x, b) 500x .44 
FIGURA 20 - Voltamograma cíclico do ETI-3 em solução de $\mathrm{KNO}_{3} \quad 0,1$ mol.L-1 e velocidade de varredura variando de 0,2 a 2,0 $\mathrm{mV} . \mathrm{s}^{-1}$

FIGURA 21 - Corrente estacionária em função da velocidade de varredura para os potenciais de $0,5,0,6$ e $0,7 \mathrm{~V}$ (vs $\mathrm{Ag} / \mathrm{AgCl}$ ) e a regressão linear segundo a Eq.13, para o ETI-3. .46

FIGURA 22 - Representação de Bode para o ETI-3 nos potenciais de 0,5, 0,6 e 0,7 V (vs. Ag/AgCl).

FIGURA 23 - Micrografias obtidas por Microscopia Eletrônica de Varredura (MEV) da superfície do ETI-3 com aumento de: a) 100x, b) 500x, c) $1000 x$

FIGURA 24 - Voltamograma cíclico do ETI- 4 em solução de $\mathrm{KNO}_{3} \quad 0,1$ mol.L-1, velocidade de varredura de 0,2 a 2,0 mV.s ${ }^{-1}$, com ampliação da região de DCE.

FIGURA 25 - Corrente estacionária em função da velocidade de varredura para os potenciais de 0,5, 0,6 e 0,7V (vs $\mathrm{Ag} / \mathrm{AgCl}$ ) e a regressão linear segundo a Eq.13 para o ETI-4 .52

FIGURA 26 - Representação de Bode para o ETI-4 nos potenciais de 0,5, 0,6 e 0,7 V (vs. $\mathrm{Ag} / \mathrm{AgCl}$ ). .53

FIGURA 27 - Micrografias obtidas por Microscopia Eletrônica de Varredura (MEV) da superfície do ETI-4 com aumento de a) 500x, b) 1000x, c) $1000 x$ .55

FIGURA 28 - Voltamograma cíclico do eletrodo de Carbono Poroso, em solução de $\mathrm{KNO}_{3}$ 0,1 mol. $\mathrm{L}^{-1}$, velocidade de varredura variando de 0,2 a $2,0 \mathrm{mV} . \mathrm{s}^{-}$ ${ }^{1}$, com ampliação da região da DCE. .56

FIGURA 29 - Corrente capacitiva em função da velocidade de varredura para os potenciais de $0,5,0,6$ e $0,7 \mathrm{~V}$ (vs. $\mathrm{Ag} / \mathrm{AgCl}$ ) para o eletrodo de 
Carbono Poroso, com os respectivos ajustes segundo a

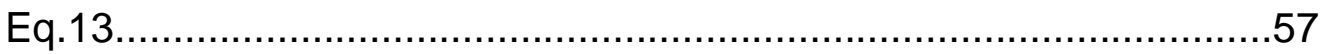

FIGURA 30 - Representação de Bode para o eletrodo de Carbono Poroso nos

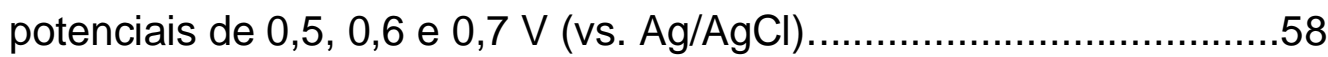

FIGURA 31 - Micrografias obtidas por Microscopia Eletrônica de Varredura (MEV) da superfície do Eletrodo de Carbono Poroso com aumento de: a) 50x, b)

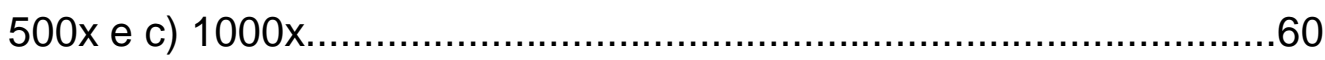

FIGURA 32 - Diagrama de Bode obtido na temperatura ambiente para as amostras dos eletrodos: Carbono Vítreo, Carbono Poroso, ETI-1, ETI-3 e ETI4 


\section{LISTA DE TABELAS}

TABELA 1 - Vantagens e desvantagens da voltametria cíclica e da espectroscopia de impedância eletroquímica usados na determinação da área superficial de diferentes materiais

TABELA 2 - Composição dos Eletrodos de Troca lônica (ETI) utilizados nos experimentos 21

TABELA 3 - Valores de $C_{d} S$ para o Carbono Vítreo e seus respectivos coeficientes de determinação

TABELA 4 - Valores do Módulo da Impedância e da Capacitância para o Carbono Vítreo em diferentes potenciais da DCE. 30

TABELA 5 - Valores de $C_{d} S$ e seus respectivos coeficientes de determinação para o ETI-1 $\left(1 \mathrm{~cm}^{2}\right)$.

TABELA 6 - Valores do módulo da impedância e da capacitância para o ETI-1 $\left(1 \mathrm{~cm}^{2}\right)$

TABELA 7 - Valores de $\mathrm{C}_{d} \mathrm{~S}$ e o Coeficiente de Determinação para o ETI-1 $\left(3,1 \mathrm{~cm}^{2}\right)$ 41

TABELA 8 - Valores do módulo da impedância e da capacitância para o ETI-1 $\left(3,1 \mathrm{~cm}^{2}\right)$

TABELA 9 - Valores de $C_{d} S$ e seus respectivos Coeficiente de Determinação para o ETI-3

TABELA 10 - Valores do módulo da impedância e da capacitância para o ETI-

TABELA 11 - Valores de $C_{d} S$ e do coeficiente de determinação para o ETI- 
TABELA 12 - Valores do módulo da impedância e da capacitância para o ETI-

TABELA 13 - Valores de $C_{d} S$ e do coeficiente de determinação para o eletrodo de Carbono Poroso.

TABELA 14 - Valores do módulo da impedância e da capacitância para o eletrodo de Carbono Poroso............................................................59

TABELA 15 - Valores de capacitância para os eletrodos estudados por condutância e impedância. .63

TABELA 16 - Valores de área superficial ativa para os eletrodos envoltos com Durepox pelos métodos eletroquímicos. 64

TABELA 17 - Valores de área superficial ativa para os eletrodos estudados pelos métodos de BET e eletroquímicos 66 


\section{GLOSSÁRIO DE SÍMBOLOS E ABREVIATURAS}

VC - Voltametria Cíclica

EIE - Espectroscopia de Impedância Eletroquímica

$\mathrm{CaC}$ - Células a Combustíveis

DCE - Dupla Camada Elétrica

EQM - Eletrodo Quimicamente Modificado

EPCM - Eletrodo de Pasta de Carbono Modificado

PWR - Reatores Nucleares de Potência de Água Pressurizada

$v$ - Velocidade de Varredura

$\mathrm{C}_{\mathrm{d}}$ - Capacitância

$\mathrm{i}_{\mathrm{s}}$ - Corrente Estacionária

$\mathrm{i}_{\mathrm{t}}$ - Corrente Transitória

MEV - Microscopia Eletrônica de Varredura

ETI- Eletrodo de Troca lônica

ECV - Eletrodo de Carbono Vítreo

$S$ - Área Superficial Ativa

|Z| - Módulo da Impedância

$\mathrm{R}^{2}$ - Coeficiente de Determinação

$\Phi$ - Ângulo de Fase

q-Carga 


\section{INTRODUÇÃO}

A eletroquímica vem aumentando cada vez mais o seu campo de aplicação nas últimas décadas. Além dos já conhecidos processos de obtenção de alumínio e de galvanização (apenas para citar dois exemplos tradicionais), a sua característica de um processo "limpo", por não necessitar a introdução de diferentes reagentes químicos, vem despertando interesse no desenvolvimento de processos de tratamento de rejeitos e, principalmente, na produção de energia, como é o caso das células a combustíveis $(\mathrm{CaC})$.

Métodos eletroquímicos para as análises de superfícies de eletrodos vêm sendo utilizados, para a determinação da superfície ativa, principalmente nos eletrodos em que são utilizadas misturas de diferentes materiais, como nos eletrodos de troca iônica, eletrodos de células a combustível, etc. Em todos estes casos, o material predominante é o carbono que é um material poroso.

Materiais porosos, especialmente o carbono e o carbono ativado, são caracterizados pela sua grande área superficial e porosidade. $\mathrm{O}$ conhecimento das propriedades estruturais destes materiais é importante para o aprimoramento de suas aplicações. A interface entre o material do eletrodo sólido e o eletrólito deve ser bem conhecida, pois as cargas são estocadas nos microporos ou próximas desta interface. Estes materiais são usados, também, como matrizes para catalisadores sólidos, como fornecedores de sítios ativos para separação de materiais de interesse, como coletores de corrente ou, ainda, em reatores sólidogás, para citar alguns exemplos ${ }^{[1,2,3]}$.

O carbono constitui-se num material de especial importância sendo o componente básico dos eletrodos empregados na troca iônica eletroquímica e nos estudos dos eletrocatalisadores para células a combustível ( $\mathrm{CaC})$. Estes eletrodos possuem uma superfície extremamente irregular, cuja área superficial deve ser 
bem conhecida para a determinação das densidades de corrente utilizadas nos processos $^{[4,5,6,7,8]}$.

O método usualmente empregado na determinação da área superficial é a análise das isotermas de adsorção/dessorção usando os modelos de BET (Brunauer, Emmett e Teller) ou BJH (Barrett, Joyner e Halenda) ${ }^{[9,10]}$. Os porosímetros por Intrusão de mercúrio são normalmente usados na determinação das propriedades estruturais dos poros dos materiais ${ }^{[11]}$. A normalização por carga de $\mathrm{CO}$ adsorvida para a caracterização in situ do catalisador de $\mathrm{CaC}$ é outra técnica empregada na determinação da área eletroquimicamente ativa de eletrodos mas, neste caso isto refere-se à área superficial de partículas de metal, as quais estão ao mesmo tempo em contato com o eletrólito (neste caso Nafion) e com o coletor de corrente (usualmente tecido de carbono ou papel carbono) ${ }^{[12,13 \text {, }}$ 14].

Devido às propriedades de condução eletrônica do carbono, o uso de métodos eletroquímicos, que empregam a Voltametria Cíclica (VC) e a Espectroscopia de Impedância Eletroquímica (EIE), possibilita a determinação da área superficial deste material, por meio do conhecimento de suas correntes capacitivas. Diferentemente dos métodos anteriormente citados, nos quais os materiais estão em contato com um gás, nestas duas técnicas eletroquímicas os materiais estão em contato com uma solução eletrolítica ${ }^{[1,14,15]}$.

A VC é uma técnica eletroanalítica onde informações qualitativas e quantitativas são obtidas a partir do registro da curva de corrente versus potencial em uma solução eletrolítica. A VC consiste na aplicação de um potencial variável em função do tempo com uma determinada velocidade de varredura de potenciais, num processo cíclico. Geralmente nesta técnica são utilizados três eletrodos: o eletrodo de trabalho, no qual a reação de interesse ocorre num potencial aplicado, relativamente a um eletrodo de referência $(\mathrm{Ag} / \mathrm{AgCl})$ no qual não há fluxo de corrente, sendo o circuito completado por um eletrodo auxiliar ou contra-eletrodo, normalmente platina ${ }^{[16]}$. 
Este tipo de determinação eletroquímica, VC, é particularmente interessante no que se refere à interface sólido-líquido, mas sua aplicação é limitada aos materiais condutores eletrônicos ${ }^{[17,18]}$.

Este método tem sido também empregado com sucesso na determinação da área superficial de diferentes tipos de carbono, carbono ativado e nanotubos de carbono em contato com líquidos iônicos (substâncias orgânicas que apresentam maior estabilidade eletroquímica) ${ }^{[19-21]}$.

A EIE é uma técnica eletroanalítica onde se aplica um potencial de corrente alternada com diferentes valores de frequência. Este método apresenta as seguintes vantagens:

Utiliza sinais pequenos que não perturbam as propriedades do eletrodo;

$\checkmark$ Em uma mesma medida calcula-se resistência de polarização e a capacitância da dupla camada;

$\checkmark$ A visualização e a análise dos resultados experimentais podem ser alcançados por meio de diferentes representações gráficas, por exemplo, Representação de Nyquist, Representação Linear, Representação Monologarítmica e Representação de Bode.

$\mathrm{Na}$ TAB.1 estão resumidas as vantagens e desvantagens de cada método citado para a determinação da área superficial de diferentes materiais.

Mediante o exposto, no presente trabalho, a união das duas técnicas, VC e EIE, permitirá que os eletrodos à base de carbono, como os eletrodos de troca iônica e outros materiais com superfície porosa irregular, tenham suas áreas superficiais ativas determinadas de maneira mais rápida e simples. 
TABELA 1 - Vantagens e desvantagens da voltametria cíclica e da espectroscopia de impedância eletroquímica usados na determinação da área superficial de diferentes materiais.

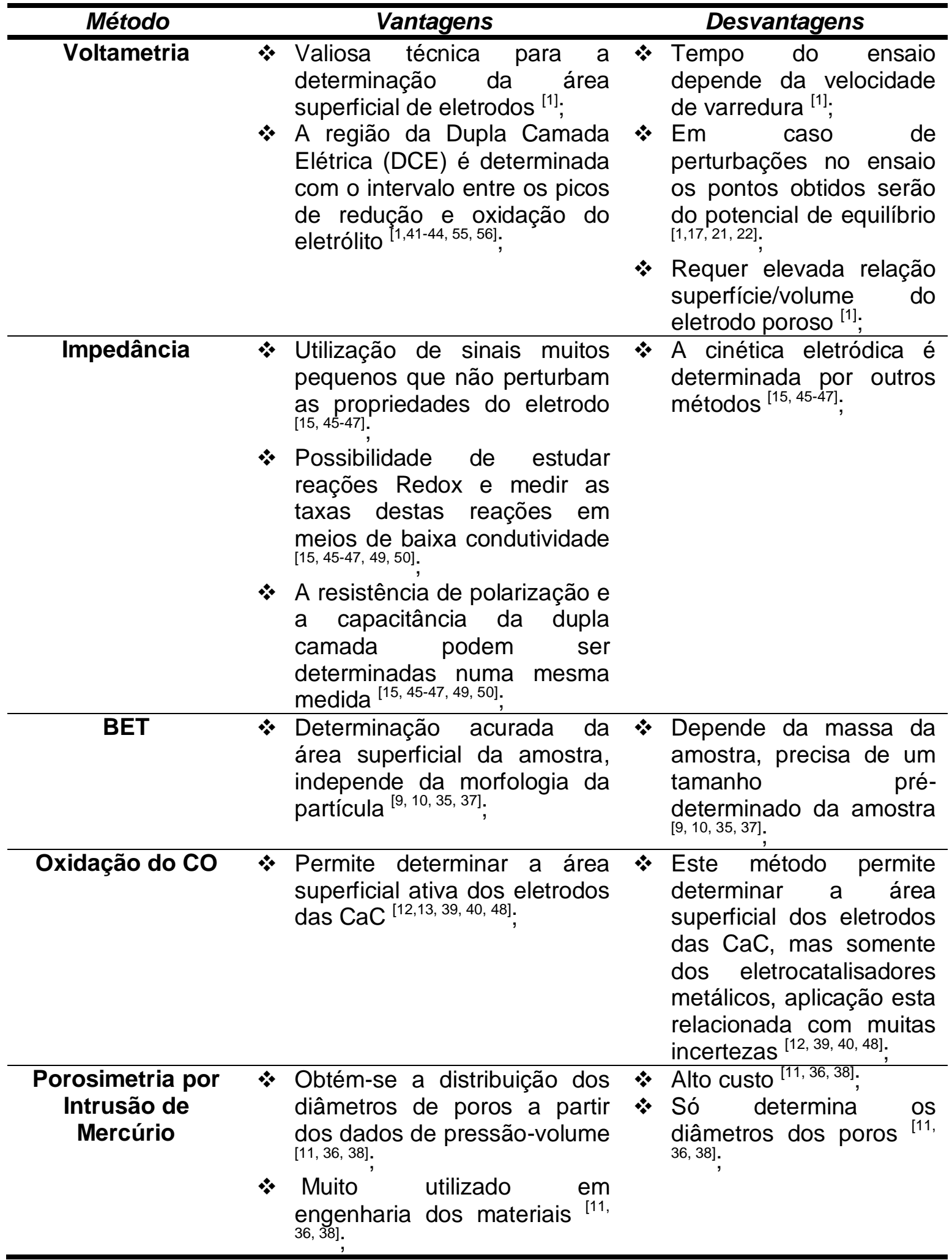




\section{OBJETIVO}

No presente trabalho pretende-se unir duas técnicas eletroquímicas, Voltametria Cíclica (VC) e Espectroscopia de Impedância Eletroquímica (EIE), para a determinação da área superficial ativa de eletrodos modificados à base de carbono. 


\section{REVISÃO BIBLIOGRÁFICA}

A denominação de eletrodos quimicamente modificados (EQMs) foi sugerida por Murray et al. na década de 70 para definir eletrodos com espécies quimicamente ativas devidamente imobilizadas na superfície desses dispositivos $^{[22,23]}$.

Os EQMs são construídos adicionando-se espécies quimicamente ativas imobilizadas no substrato do eletrodo, objetivando estabelecer e controlar a natureza físico-química da interface eletrodo/solução. A modificação do eletrodo por agentes modificadores conferem à superfície eletródica propriedades específicas, tais como, eletrocatálise ${ }^{[24]}$ e pré-concentração, sendo esta última muito empregada para a determinação de metais. Nesse aspecto, são encontradas na literatura diversas revisões que descrevem as diferentes estratégias para construção de eletrodos modificados ${ }^{[22,23]}$.

No final da década de 70 vários trabalhos foram publicados empregando modificações de eletrodos, sendo que no início dos anos 80 ocorreu um marco na história dos eletrodos de pasta de carbono modificados (EPCMs): o desenvolvimento de um sensor modificado com dimetilglioxima para a determinação de íons $\mathrm{Ni}\left(\right.$ II) ${ }^{[25]}$. Neste trabalho, verificou-se que o uso de um reagente seletivo clássico proporcionou aumento significativo da seletividade do eletrodo. A superfície dos eletrodos de pasta de carbono é muito complexa, com muitas possibilidades de interações. O líquido orgânico aglutinante serve para fixar a pasta ao eletrodo, preencher as cavidades entre as partículas de grafite e "isolar" o mesmo do contato com soluções aquosas; também deve ser eletroinativo, possuir baixa volatilidade e não conter impurezas ${ }^{[22]}$. 
Dos materiais comumente empregados como agentes modificadores na preparação de EPCM para a pré-concentração de metais pode-se citar como exemplos: sílicas organofuncionalizadas, compostos orgânicos, zeólitas e também resinas de troca-iônica. Resinas de troca iônica são compostas por polímeros do estireno e divinilbenzeno, funcionalizadas com grupos trocadores iônicos, sais quaternários de amônia, para resinas aniônicas, e grupamentos sulfônicos $\left(-\mathrm{SO}_{3}^{-}\right)$e carboxílicos (-COO-), para as resinas catiônicas ${ }^{[22]}$.

Murphy e Arnold ${ }^{[26]}$ entre os anos de 1957 a 1970 conduziram uma equipe para trabalhar com eletrodos modificados à base de carbono na remoção de ânions $\mathrm{e}$ cátions da água do mar. Evans e Hamilton (1966) ${ }^{[27,28]}$ iniciaram estudos para o desenvolvimento de eletrodos de troca iônica que possuíam resinas em sua composição.

A vantagem desse material é a produção de eletrodos tanto catiônicos quanto aniônicos, igualmente efetivos na dessalinização da solução remoção/recuperação de metais em soluções aquosas, descontaminação de efluentes produzidos em Reatores Nucleares de Potência de Água Pressurizada (PWR), na separação de radioisótopos do tanque de estocagem de rejeitos radioativos, na remoção seletiva e recuperação de metais preciosos das operações de refinamento de metais, na remoção da prata das águas de lavagem provenientes da revelação fotográfica, na remoção de metais tóxicos, como o arsênio, presentes na água potável, etc ${ }^{[4,26,27,28,29]}$.

\subsection{Princípios da troca iônica eletroquímica}

Trocadores catiônicos necessitam de um meio básico para a remoção de espécies catiônicas presentes em uma solução. Em eletrólitos neutros a adsorção 
eletroquímica remove este obstáculo pela geração de um meio alcalino próximo ao eletrodo ${ }^{[4,29,30,31]}$ :

$\mathrm{H}_{2} \mathrm{O}+\dot{e} \rightarrow \mathrm{H}_{a d s}+\mathrm{OH}^{-}$

Isto eleva o pH da solução, favorecendo a formação de sítios ativos pela ionização:

$\mathrm{RCOOH}+\mathrm{OH}^{-} \rightarrow \mathrm{RCOO}^{-}+\mathrm{H}_{2} \mathrm{O}$

onde $\mathrm{RCOOH}$ é o grupo funcional da resina e $\mathrm{RCOO}^{-}$é o sitio ativo.

A reação de troca é dada pela seguinte equação:

$\mathrm{RCOO}^{-}+\mathrm{A}^{+} \rightarrow \mathrm{RCOOA}$

onde:

$$
A=\text { cátion a ser adsorvido. }
$$

A dessorção é feita pela inversão da polaridade dos eletrodos, resultando nas seguintes reações:

$H_{a d s} \rightarrow H^{+}+\dot{e}$

$$
\mathrm{RCOOA}+\mathrm{H}^{+} \rightarrow \mathrm{RCOOH}+A^{+}
$$

Os eletrodos de troca iônica eletroquímica desenvolvidos por Evans e Hamilton ${ }^{[27,28]}$ consistiam em uma resina de troca iônica, carvão, pó de grafite e um aglutinante. Atualmente outros eletrodos empregados na troca iônica e nos estudos dos eletrocatalisadores para a células a combustível $(\mathrm{CaC})$ estão sendo 
desenvolvidos. Estes eletrodos possuem uma superfície extremamente irregular cuja área superficial ativa deve ser conhecida/determinada ${ }^{[31,32,33,34]}$.

\subsection{Métodos utilizados na determinação de área superficial}

Os métodos usualmente empregados na determinação da área superficial são:

$\checkmark$ Análise das isotermas de adsorção/dessorção usando o modelo de BET (Brunauer, Emmett e Teller);

$\checkmark$ Porosímetros de Mercúrio - normalmente usados para determinação das propriedades estruturais dos poros dos materiais;

$\checkmark$ Normalização por carga de CO adsorvida na superfície dos eletrodos;

$\checkmark$ Condutância e Impedância;

\subsubsection{Modelo BET}

A forma empírica de uma isoterma de adsorção foi reconhecida em 1926 por Freundlich ${ }^{[35]}$, e, mais tarde, foi derivada teoricamente a partir da equação de Langmuir ${ }^{[35,36]}$, com a adoção do mecanismo de Langmuir e a introdução de uma série de hipóteses simplificadoras, os pesquisadores Brunauer, Emmet e Teller desenvolveram o método de $\mathrm{BET}{ }^{[9,35,36,37]}$, para determinar a efetiva área de materiais sólidos que apresentam complicadas formas, tais como os materiais particulados porosos. A superfície de um pó é um fator importante que determina muitas de suas propriedades. Existem vários métodos de avaliação desta área, mas a resposta em cada caso depende muito do método e da propriedade utilizada ${ }^{[37]}$.

Por meio da análise das isotermas de adsorção/dessorção obtém-se a área total do material com boa precisão. Ou seja, pela efetiva área de cada uma das moléculas de gás adsorvido pelo material sólido pode-se determinar sua área total $^{[9,35,36]}$. Isto resulta na seguinte equação que descreve a isoterma: 


$$
\frac{P}{X\left(P_{0}-P\right)}=\frac{1}{X_{m} C}\left[1+\frac{P}{P_{0}}(C-1)\right]
$$

onde:

$$
\begin{aligned}
& P=\text { Pressão parcial do gás; } \\
& P_{0}=\text { Pressão de vapor de saturação; } \\
& X=\text { Quantidade de gás adsorvida a pressão } P \text {; } \\
& X_{m}=\text { Quantidade de gás necessária para saturar a superfície com uma } \\
& \text { monocamada atômica; } \\
& C=\text { Constante relacionada com a entalpia de adsorção; }
\end{aligned}
$$

Com a determinação de $X_{m}$, a área especifica da amostra é calculada pela seguinte expressão:

$$
S=\frac{X_{m} N_{0} A_{0}}{w M}
$$

onde:

$S=$ Área especifica da amostra;

$N_{0}=$ Número de Avogadro;

$A_{0}=$ Área de ocupação média da molécula de gás;

$w=$ Massa da amostra;

$M=$ Mol do gás;

\subsubsection{Porosimetria por Intrusão de Mercúrio}

A técnica de porosimetria por intrusão de mercúrio foi proposta por Washburn em 1921. Por este método obtém-se a distribuição dos diâmetros de poros 
a partir dos dados de pressão-volume durante a penetração de mercúrio em um material poroso. Este método é muito utilizado em engenharia dos materiais, pois a forma, o tamanho e o volume dos poros que um material apresenta podem torná-lo útil para diferentes aplicações como filtros, membranas, catalisadores, concretos, cerâmicas, solos, papel, implantes ósseos entre outros ${ }^{[10,11,38]}$.

\subsubsection{Normalização por carga de CO adsorvida na superfície dos eletrodos}

Vidakovic et al. ${ }^{[12,13]}$ estudaram a área superficial dos catalisadores metálicos dos eletrodos de $\mathrm{CaC}$ com eletrocatalisadores de Pt/C-Ru pelo método da normalização por carga de CO adsorvida na superfície dos eletrodos. O CO adsorvido na superfície do catalisador foi oxidado com velocidade de varredura de 2,0 a $100 \mathrm{mV} \cdot \mathrm{s}^{-1}$, temperatura constante de $60^{\circ} \mathrm{C}$ e em outras temperaturas. Com os dados obtidos experimentalmente, desenvolveram um modelo matemático. Concluíram que os desvios observados entre o modelo e os valores experimentais foram da ordem de $2 \%$ na velocidade de varredura de $2 \mathrm{mV} . \mathrm{s}^{-1}$ e de $8,8 \%$ a 100 $\mathrm{mV} . \mathrm{s}^{-1}$. De acordo com o modelo, cerca de $8,9 \%$ da carga total de CO é consumida até o potencial de meia-onda e o valor praticamente não muda com a velocidade de varredura $^{[12,13,39,40]}$.

Este método permite determinar a área superficial real das células a combustível, mas somente para catalisadores de metais. No entanto, sua aplicação esta relacionada com muitas incertezas. Algumas delas surgem do tipo desconhecido de ligação do CO sobre a superfície. No caso do catalisador PtRu este problema é a formação significativa de óxido sobre o catalisador de PtRu. Por esta razão, a determinação da carga voltamétrica de CO é normalmente usado de forma qualitativa e afirma que o valor da área superficial (se for dado) é apenas um valor relativo e não absoluto ${ }^{[12,39,40]}$. 
A normalização por carga de CO adsorvida na superfície dos eletrodos pode ser acompanhada por Infravermelho (IR) ou por Espectrometria de Massas Eletroquímica Diferencial (DEMS). Estas técnicas têm uma vantagem maior quando comparado com a normalização da carga de CO por voltametria, principalmente porque não há contribuições de correntes faradáicas e não-faradáicas. Contudo, existem algumas desvantagens, como a aplicabilidade destas técnicas nos laboratórios de células a combustível e em um catalisador real. Esta questão é especialmente importante na determinação de perda da atividade catalítica durante a operação em longo prazo de células a combustível ${ }^{[12,13]}$.

\subsubsection{Condutância}

Burke e Murphy ${ }^{[40]}$ descreveram a voltametria cíclica como uma valiosa técnica para a determinação da área superficial de eletrodos. Nesta técnica a determinação da área superficial é realizada por um método baseado na eletroquímica, onde os materiais (eletrodos) são imersos em uma solução eletrolítica e obtém-se a medida da corrente capacitiva em potenciais onde nenhuma reação eletroquímica ocorre, ou seja, na região da Dupla Camada Elétrica (DCE). Esta corrente capacitiva, medida em velocidades de varredura diferentes, permite a determinação direta da superfície de contato entre o eletrólito e a condução eletrônica. O método proposto requer condições de eletrólise total (elevada relação superfície/volume do eletrodo poroso) sem transferência de massa por convecção ${ }^{[1,}$ $41,42,43,44]$.

Determina-se a região da DCE por voltametria cíclica considerando o intervalo entre os picos de redução e oxidação da solução eletrolítica. Assume-se que:

$C=C_{d} S$

onde: 


$$
\begin{aligned}
& C=\text { Capacitor }(\mu \mathrm{F}) ; \\
& C_{d}=\text { Capacitância }\left(\mu \mathrm{F} . \mathrm{cm}^{-2}\right) ; \\
& S=\text { Área superficial ativa do eletrodo }\left(\mathrm{cm}^{2}\right) ;
\end{aligned}
$$

O potencial obtido, E, consiste em uma variação linear, em função da velocidade de varredura, $v,\left(\mathrm{~V} . \mathrm{s}^{-1}\right)$ :

$$
E=E_{i}+v t
$$

onde:

$$
\begin{aligned}
& E_{i}=\text { Potencial inicial }(\mathrm{V}) \\
& v=\text { Velocidade de Varredura }\left(\mathrm{V} . \mathrm{s}^{-1}\right) \\
& t=\text { Tempo }(\mathrm{s}) ;
\end{aligned}
$$

Substituindo a Eq.9 na equação abaixo, obtém-se:

$$
E=E_{R}+E_{C}
$$

onde:

$$
\begin{gathered}
R=\text { Resistência ôhmica; } \\
C=C_{d} S=\text { Capacitor; } \\
E_{i}+v t=R_{S}\left(\frac{d q}{d t}\right)+\frac{q}{C_{d} S} \\
\mathrm{q}=\text { Carga; }
\end{gathered}
$$

que leva à equação (com $q \rightarrow 0$ e $t \rightarrow 0)$ : 
$i=C_{d} S v+\left\{\left(\frac{E_{i}}{R_{S}}-C_{d} S v\right) \exp \left(-\frac{t}{R_{S} C_{d} S}\right)\right\}$

A corrente pode assim ser dividida em dois termos. O primeiro, is, que corresponde à parte estacionária $\left(C_{d} S v\right)$ e a segunda, $\mathrm{i}_{\mathrm{t}}$, à parte transitória, que decresce exponencialmente com o tempo.

Para pequenos valores da velocidade de varredura $v$ pode-se considerar:

$i_{S}=C_{d} S v$

A determinação da capacitância da DCE de materiais de carbono é feita por medidas iniciais em eletrodo de carbono vítreo, com superfície devidamente polida de modo a assumir que a sua área geométrica é igual à sua área superficial. As correntes capacitivas do carbono vítreo de área superficial conhecida são colocadas em função da velocidade de varredura. Ao fazer a regressão linear destes pontos é possível determinar o coeficiente angular que fornece o valor de $C_{d} S$, segundo a Eq.13. Como a área geométrica do carbono vítreo é conhecida, obtém-se assim o valor de $C_{d}{ }^{[1,41,42,43,44]}$.

\subsubsection{Impedância}

A Espectroscopia de Impedância Eletroquímica (EIE), nome proposto por Mansfeld et al. ${ }^{[45]}$ (1988), permite a determinação da capacitância $C_{d}$. Neste método aplica-se um potencial de corrente alternada com diferentes valores de freqüência ${ }^{[45]}$.

EIE é uma técnica muito usada na caracterização de revestimento de metais com proteções orgânicas. Por este método obtém-se informação sobre a propriedade do sistema, tais como a presença de defeitos, reatividade da interface, adesão, etc. Conhecimentos desses parâmetros são muito úteis para predizer 
comportamentos corrosivos nas superfícies. Os trabalhos de Mansfeld et al. ${ }^{[45]}$ propõem dois circuitos para modelar o sistema corrosivo. O primeiro é formado pela capacitância $\left(\mathrm{C}_{\mathrm{d}}\right)$ em paralelo com a resistência os quais descrevem reações eletroquímicas. Já o segundo circuito considera um elemento Warburg (W) ${ }^{[46,47]}$.

Boggio et al. [48] utilizaram a EIE para medir a capacitância na determinação de área superficial de eletrodos de óxidos de $\mathrm{Co}_{3} \mathrm{O}_{4}$.

Dentre as diversas representações gráficas, que este método possibilita, a que será utilizada no cálculo da capacitância será a de Bode, que consiste na representação de $\log |Z|$ versus $\log \omega$.

O módulo da impedância, $|Z|$ é obtido através da seguinte relação:

$|Z|=\sqrt{Z_{r}^{2}+Z_{i}^{2}}$

Sendo, $Z_{r}$ e $Z_{i}$ os valores da impedância real e imaginária, respectivamente, esses valores foram obtidos numa faixa de freqüência de 6 a 5000 Hz. Para freqüências intermediárias $|Z|$ é inversamente proporcional a freqüência, $\omega$, e, assim, obtém-se, na região de transição entre os dois patamares horizontais, uma reta de declive $s=-1$. $O$ valor de $C_{d}$ pode ser determinado por meio da extrapolação dessa reta para $\omega=1$ (ou $\log \omega=0)^{[45,49,50]}$, onde:

$|Z|=1 / C_{d}$ 


\section{PARTE EXPERIMENTAL}

\subsection{Materiais e Equipamentos}

Os seguintes equipamentos e materiais foram utilizados:

$\checkmark$ Potenciostato/Galvanostato PGSTAT 30, marca AUTOLAB;

$\checkmark$ FRA: Frequency Response Analyser PGSTAT 302N, marca AUTOLAB;

$\checkmark$ Balança Analítica, marca Sartorius;

$\checkmark$ Eletrodo de Referência de Ag/AgCl; marca Digimed;

$\checkmark$ Eletrodos de trabalho:

- Eletrodo de Carbono Vítreo marca Metrohm;

- Eletrodos de Troca lônica Eletroquímica;

- Eletrodo de Carbono Poroso, marca EG\&G;

$\checkmark$ Contra-Eletrodo de Placa de Platina com área de $4 \mathrm{~cm}^{2}$;

$\checkmark$ Nitrato de Potássio $\left(\mathrm{KNO}_{3}\right)$, marca Merck;

$\checkmark$ Resina catiônica Amberlite CG-50, marca BDH Reagents;

$\checkmark$ Pó de Grafite fino, marca Merck;

$\checkmark \quad$ Feltro de carbono, marca SGL Carbon do Brasil;

$\checkmark \quad$ Kraton® 1101, marca Kraton Polymers;

$\checkmark \quad$ Carvão Norit A, marca J. T. Baker Chemical Co, USA

\subsection{Preparação das Soluções}

As medidas eletroquímicas foram realizadas em uma solução de $\mathrm{KNO}_{3} 0,1$ mol. $\mathrm{L}^{-1}$. A região da $\mathrm{DCE}$ se estendeu de $0,5 \mathrm{~V}$ à $1,0 \mathrm{~V}(\mathrm{vs} \mathrm{Ag} / \mathrm{AgCl})$ para diferentes velocidades de varredura $\left(0,2\right.$ à $\left.2,0 \mathrm{mV} \cdot \mathrm{s}^{-1}\right)$. A escolha deste intervalo de velocidade deve-se à obtenção da corrente estacionária, o que facilita o cálculo da área superficial ${ }^{[1]}$. 


\subsection{Eletrodos de Trabalho}

\subsubsection{Eletrodo de Carbono Vítreo (ECV)}

O carbono vítreo é um material altamente poroso que apresenta características que variam de semicondutor a condutor elétrico. Sendo este biocompatível, apresenta diversas áreas de aplicação, como por exemplo, armazenamento de energia (baterias e capacitores), proteção térmica de aeronaves, suporte para a cultura de tecidos e também para aplicações internas em próteses, servindo como substrato para a moldagem de ossos, e eletrodos. Suas propriedades elétricas permitem sua utilização em diversos tipos de eletrodos, sendo possível ajustar a condutividade elétrica por meio da adição de determinados metais à resina precursora, e/ou variando as condições de processamento do material ${ }^{[51,52]}$.

A designação carbono vítreo é dado ao material não ordenado considerando toda a extensão de sua rede cristalina, apresentando aparência vítrea quando polido. Pelo fato de ser altamente poroso e quimicamente inerte a aplicação deste eletrodo em células eletrolíticas deve-se à: alta estabilidade térmica, alta resistência a ataques químicos. É um material praticamente impermeável a gases e líquidos. Diferentes tipos de pré-tratamento, como por exemplo, polimento mecânico, ultrassom, tratamento térmico a vácuo, irradiação com laser e o pré-tratamento eletroquímico melhoram o seu desempenho eletroquímico e aderência, além de $\sim 98 \%$ do seus poros serem de transportes ${ }^{[52,53,54,55]}$. A FIG.1 mostra a representação estrutural do carbono vítreo e suas "fitas grafíticas" de aproximadamente $100 \AA$ de comprimento $\left(L_{a}\right)$ e $30 \AA ̊$ na secção cruzada $\left(L_{c}\right)$.

O ECV utilizado nos experimentos (FIG.2) é um eletrodo empregado em determinações analíticas (marca Metrohm) e possui uma superfície polida. Portanto, a sua área superficial foi assumida como sua área geométrica, com um valor de $3,14 \times 10^{-2} \mathrm{~cm}^{2}$. 


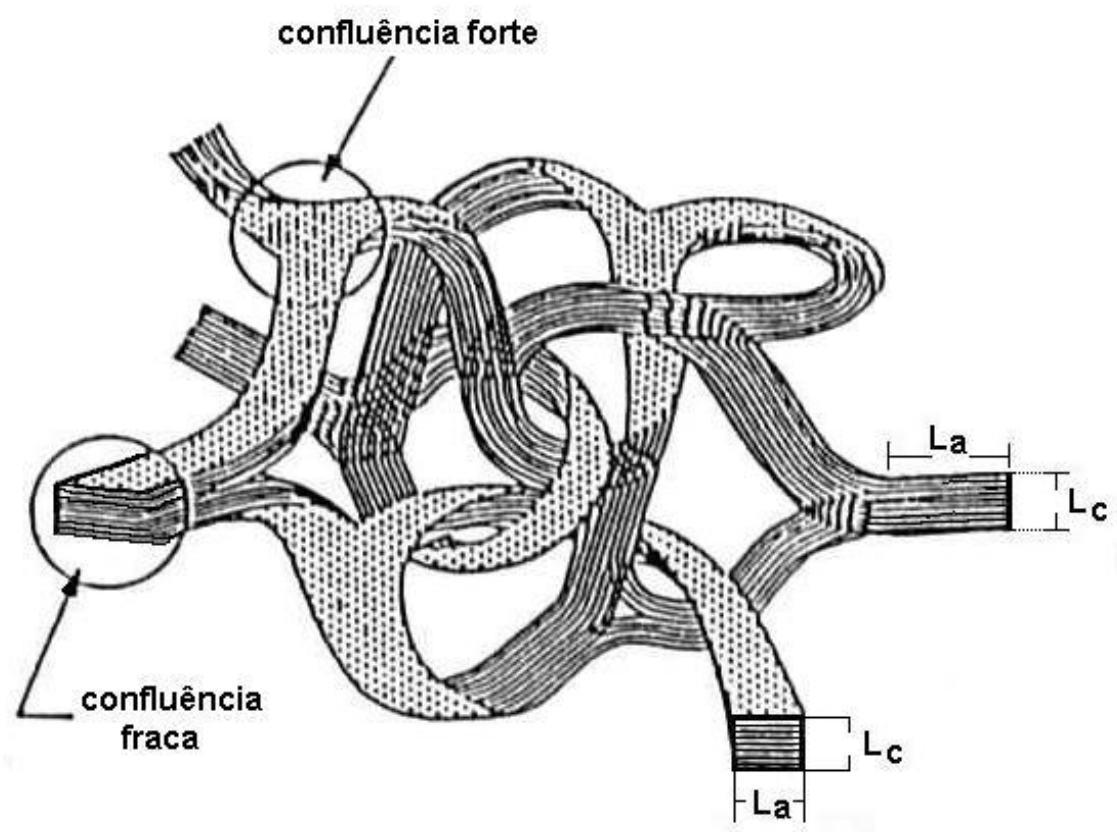

FIGURA 1 - Representação esquemática da estrutura do Carbono Vítreo (CV) ${ }^{[51]}$.

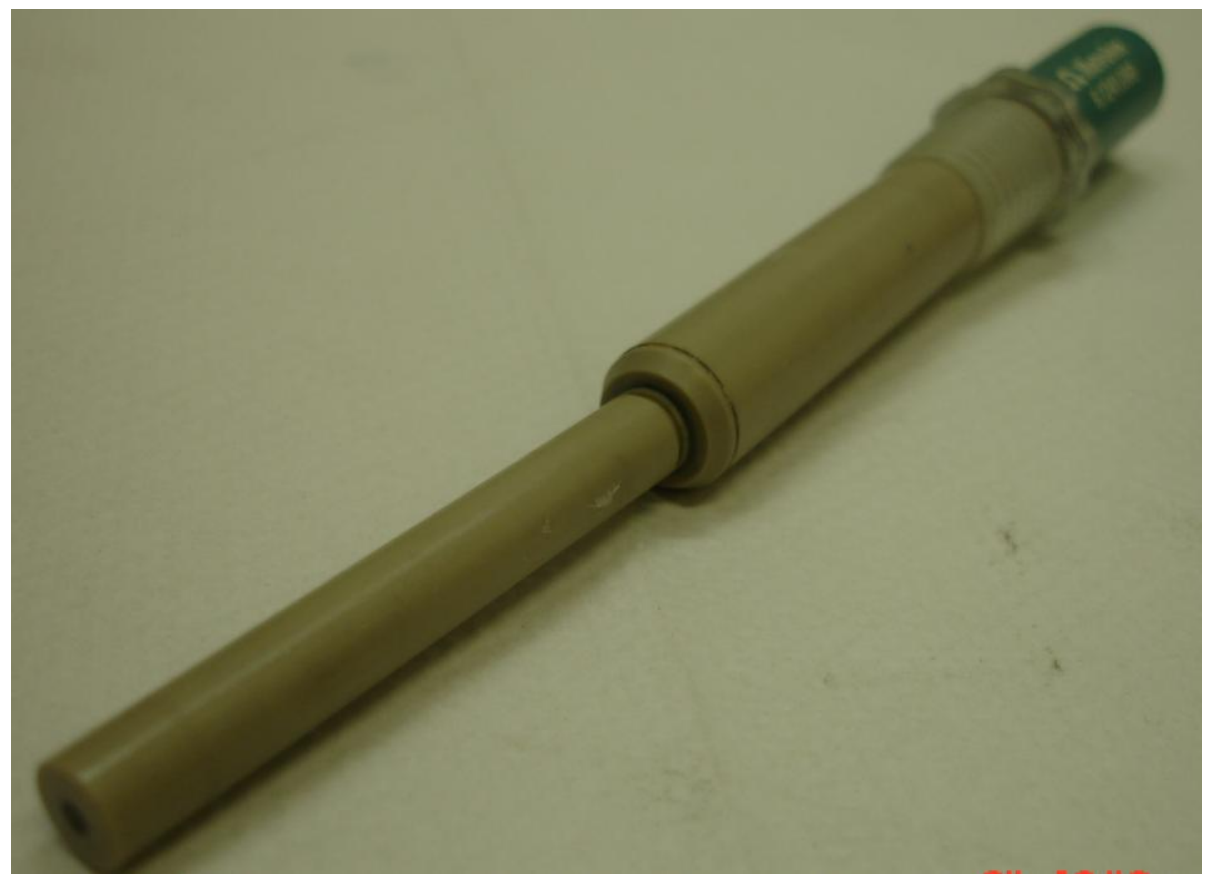

FIGURA 2 - Eletrodo de Carbono Vítreo utilizado nos experimentos. 


\subsubsection{Eletrodo de Troca lônica (ETI)}

Foram utilizados quatro ETIs baseados em estudos realizados anteriormente ${ }^{[4]}$. Para a confecção destes eletrodos foram empregados os seguintes materiais:

> Feltro de carbono, usado como coletor de corrente apresenta propriedade adesiva na aplicação da massa do eletrodo, boa condutividade elétrica e é resistente às condições do meio de trabalho. Além disso, após a confecção do eletrodo, este apresenta certa flexibilidade que facilita o manuseio na montagem da célula;

$>$ Kraton $1101^{\circledR}$, um copolímero de estireno e butadieno, que é dissolvido em tolueno na proporção de $1 / 10$, com a função de aglutinar os componentes do eletrodo;

$>$ Carvão Norit $A^{\circledast}$, utilizado para melhorar a retenção do eletrodo, pois ele ajuda na adsorção do íon hidrogênio, facilitando a criação de sítios ativos;

$>$ Pó de grafite, usado para aumentar a condutividade elétrica do eletrodo e garantir a distribuição mais uniforme da corrente por todo o eletrodo. A sua granulometria encontra-se em torno de $50 \mu m(>99,5 \%)$ o que fornece uma área de $3,14 \times 10^{-4} \mathrm{~cm}^{2}$;

> Resina catiônica fraca Amberlite CG-50 para a retenção de cátions. É uma resina de ácido fraco na forma $\mathrm{H}^{+}$, com o grupo funcional carboxílico. A granulometria da resina encontra-se entre 0,075 e 0,150 mm. Resinas aniônicas também podem ser usadas.

Para a preparação do eletrodo diluiu-se em um béquer o aglutinante Kraton em tolueno na proporção de 1:10. Em outro béquer acrescentou-se a resina 
Amberlite CG-50, o carvão Norit A e o grafite, em porcentagens variadas, conforme a TAB.2, agitando-se bem a mistura até que ficasse homogênea. Em seguida, juntaram-se as duas misturas, formando um líquido escuro e viscoso. Este líquido foi aplicado em camadas sobre o feltro de carbono com um pincel. Foram aplicadas três camadas num intervalo de uma hora entre elas, para a secagem a temperatura ambiente. Repetiu-se o procedimento do outro lado do feltro de carbono ${ }^{[4]}$. Após a pintura, o eletrodo foi cortado no tamanho padronizado de $1 \mathrm{~cm}^{2}$ (área geométrica). Para isso suas laterais e parte posterior foram cobertas com Durepox ${ }^{\circledR}$ para que não houvesse contribuição no valor da corrente por estas regiões (FIG.3).

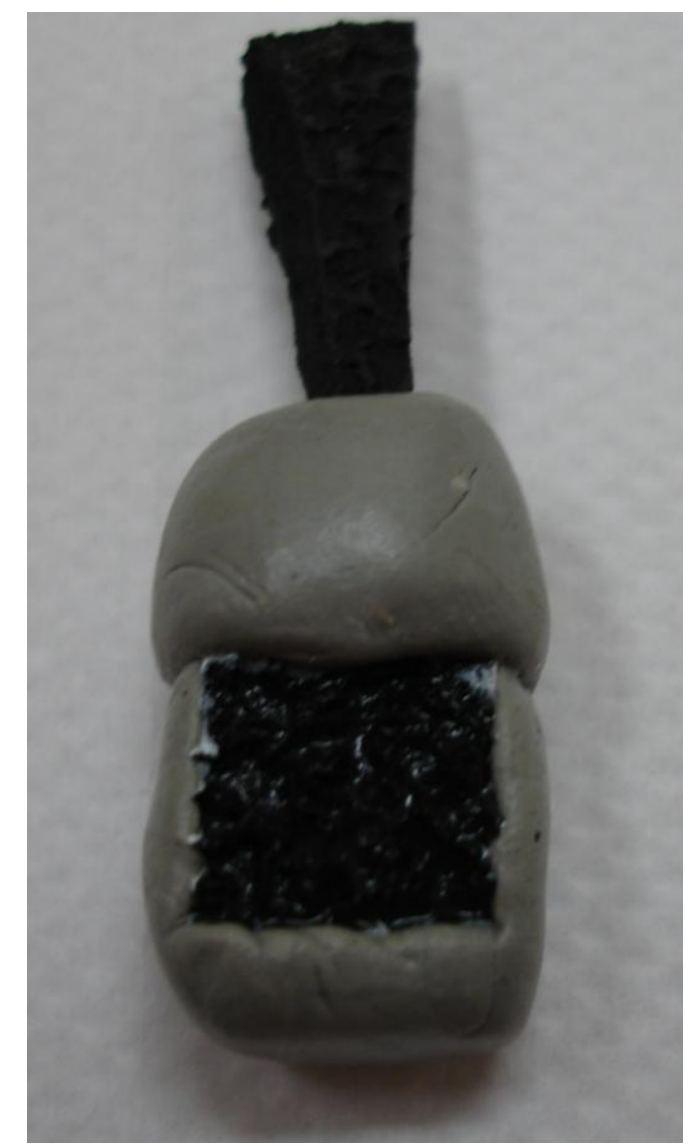

FIGURA 3 - Eletrodo de Troca lônica (ETI) confeccionado variando as porcentagens em peso dos componentes. 
TABELA 2- Composição dos Eletrodos de Troca lônica (ETI) utilizados nos experimentos.

\begin{tabular}{cc}
\hline Eletrodo & Peso (\%) \\
\hline ETI-1 & R-35 \\
& C-25 \\
& G-15 \\
& A-25 \\
\hline ETI-2 & R-35 \\
& C-30 \\
& G-25 \\
& A-10 \\
\hline ETI-3 & R-30 \\
& C-25 \\
& G-15 \\
& A-30 \\
\hline ETI-4 & R-30 \\
& C-30 \\
& G-15 \\
& A-20
\end{tabular}

$\mathrm{R}=$ resina, $\mathrm{C}=$ carvão, $\mathrm{G}=$ grafite, $\mathrm{A}=$ aglutinante

O desenvolvimento destes eletrodos deve-se à melhor retenção de metais (crômio e césio), baseado em estudos realizados anteriormente ${ }^{[4]}$.

\subsubsection{Eletrodo de Carbono Poroso (ECP)}

O uso de eletrodo de carbono poroso em eletroanálise deve-se à sua larga faixa de potencial, seu baixo custo e inércia química. Estes materiais têm uma atividade superficial elevada, explicando a sua susceptibilidade para a contaminação por compostos orgânicos. Na superfície do carbono podem ser formadas ligações 
com hidrogênio, grupos hidroxilas, carboxilas, etc, mostrando que o comportamento do eletrodo pode ser sensível ao $\mathrm{pH}^{[52,53,54,55]}$.

Para as medidas voltamétricas e de EIE foi utilizada uma haste de carbono poroso envolto com Durepox ${ }^{\circledR}$, garantindo desta maneira que apenas a base do eletrodo tivesse contato com a solução eletrolítica (FIG.4).

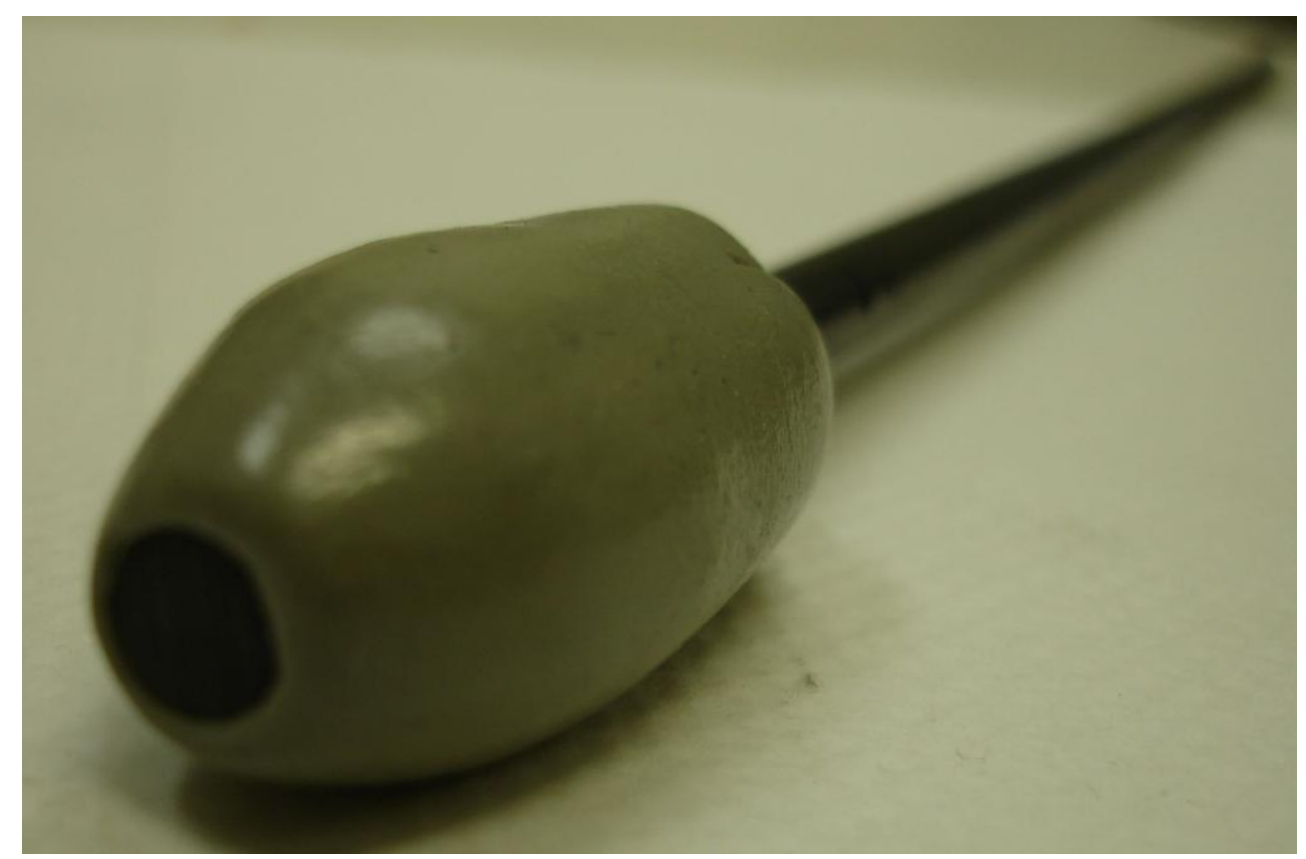

FIGURA 4 - Haste de Carbono Poroso envolta com Durepox ${ }^{\circledR}$ para delimitar a área superficial a ser analisada.

\subsection{Metodologia}

\subsubsection{Voltametria Cíclica (VC)}

A VC é uma técnica que fornece informações qualitativas e quantitativas sobre o sistema eletrodo em solução com espécies eletroativas, tornando um 
processo efetivo na capacidade de observar o comportamento redox em uma ampla faixa de potencial e a localização da DCE. Para a obtenção destas informações aplica-se um potencial variável em função do tempo com uma determinada velocidade de varredura, em um processo cíclico e reversível ${ }^{[1,56]}$.

Nos experimentos de VC foram utilizados três eletrodos: eletrodo de trabalho (diferentes eletrodos à base de carbono), eletrodo de referência de $\mathrm{Ag} / \mathrm{AgCl}$ ), e um contra-eletrodo de placa de platina. Os eletrodos foram colocados em uma célula de vidro com cerca de $150 \mathrm{~mL}$ de solução de $\mathrm{KNO}_{3}$ 0,1 mol.L-1 (FIG.5). Antes de registrar as curvas voltamétricas, três ensaios de 15 ciclos foram realizados para cada uma das velocidades de varredura, para observar a sobreposição das curvas e a estabilização da solução.

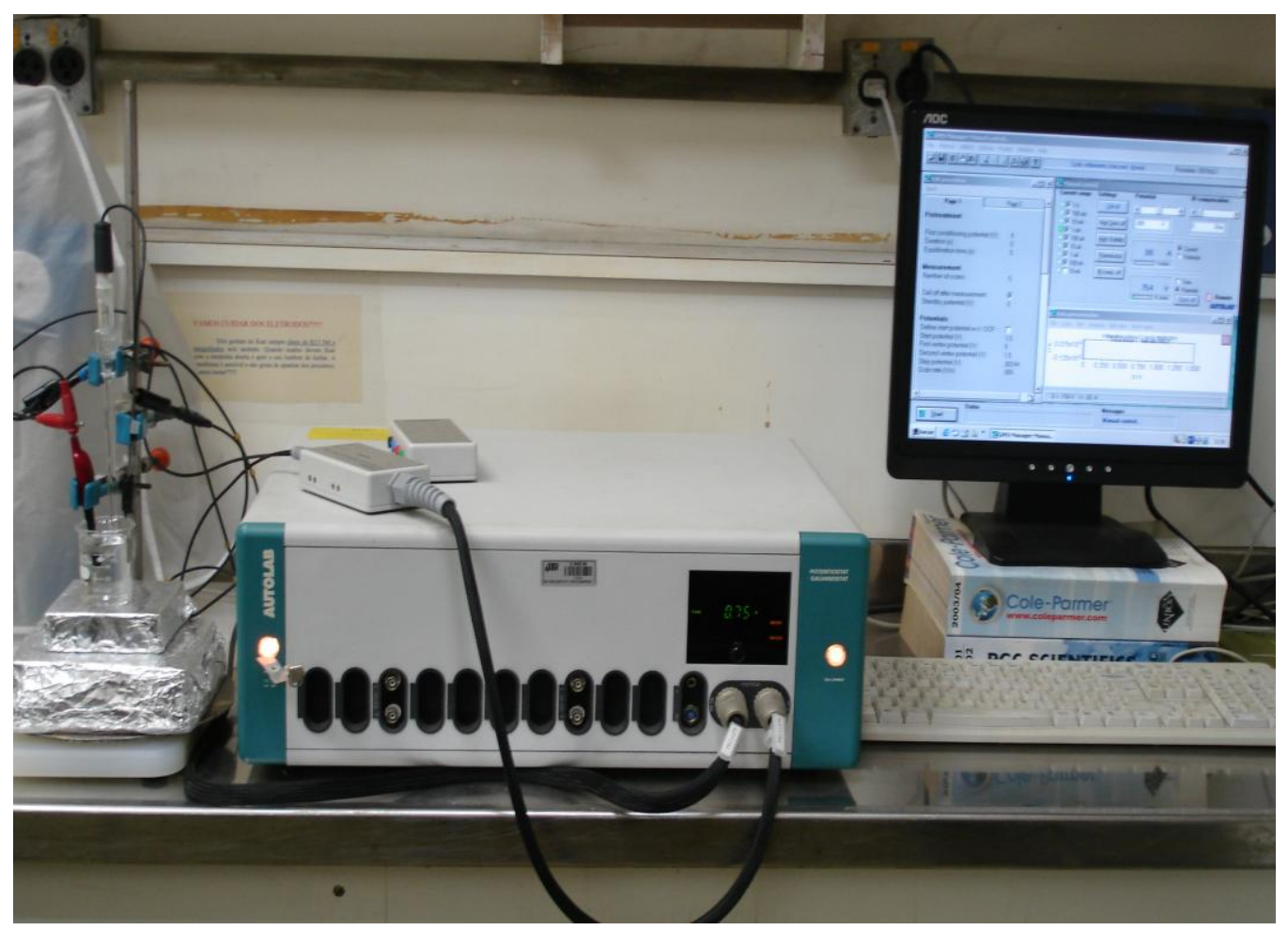

FIGURA 5 - Potenciostato/Galvanostato e célula eletrolítica utilizados nos experimentos de voltametria cíclica. 


\subsubsection{Espectroscopia de Impedância Eletroquímica (EIE)}

$\mathrm{Na}$ EIE as medidas são realizadas num sistema eletroquímico de acordo com o esquema mostrado na FIG.6.

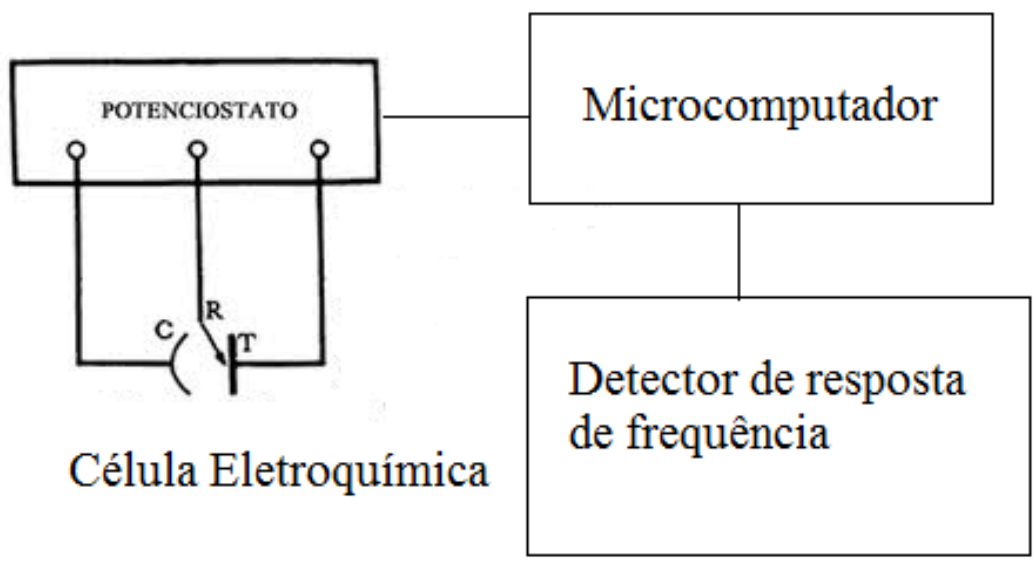

$\mathrm{C}=$ contra-eletrodo, $\mathrm{R}$ = eletrodo de referência,$T=$ eletrodo de trabalho

FIGURA 6 - Esquema para a realização das medidas de impedância AC em sistemas eletroquímicos ${ }^{[57]}$.

Como nos experimentos de VC, utilizou-se uma célula eletrolítica composta por três eletrodos: eletrodo de trabalho, contra-eletrodo de placa de platina e eletrodo de referência de $\mathrm{Ag} / \mathrm{AgCl}$. Estes eletrodos foram mergulhados em uma solução eletrólito de $\mathrm{KNO}_{3}$ 0,1 mol.L-1 e conectados ao potenciostato/galvanostato com módulo da impedância. 


\section{RESULTADOS E DISCUSSÃO}

A seguir, serão apresentados os resultados obtidos das áreas superficiais ativas dos eletrodos à base de carbono estudados, pela combinação das duas técnicas eletroquímicas, VC e EIE.

\subsection{Eletrodo de Carbono Vítreo}

$\mathrm{Na}$ determinação da capacitância do eletrodo de Carbono Vítreo utilizaram-se os dois métodos, condutância e impedância, para fins comparativos de resultados.

\subsubsection{Condutância}

Para a determinação da capacitância do eletrodo vítreo pelo método voltamétrico foram realizadas as seguintes etapas:

a) Obtenção do voltamograma cíclico para determinação da região da DCE;

b) Construção do gráfico da corrente capacitiva em função da velocidade de varredura, considerando a região linear;

c) Regressão linear destes pontos para determinar o coeficiente angular, $\mathrm{C}_{d} \mathrm{~S}$, segundo a Eq.13;

d) Obtenção do valor médio, $\overline{C_{d} S}$;

e) Determinação da capacitância.

Na FIG.7 tem-se o voltamograma do carbono vítreo realizado em solução de $\mathrm{KNO}_{3}$ 0,1 mol.L $\mathrm{L}^{-1}$ e velocidades de varredura de 0,2 a 2,0 mV.s ${ }^{-1}$. Verificou-se que a DCE está entre, 0,5 a 1,0 V (vs $\mathrm{Ag} / \mathrm{AgCl}$ ). Esta região foi ampliada para melhor visualização dos valores da corrente utilizada no cálculo de $C_{d} S$. Este gráfico mostra 
também os pontos de evolução de $\mathrm{H}_{2}$ a baixos potenciais e evolução de $\mathrm{O}_{2}$ a altos potenciais (acima de 1,5 V (vs $\mathrm{Ag} / \mathrm{AgCl})$ ).

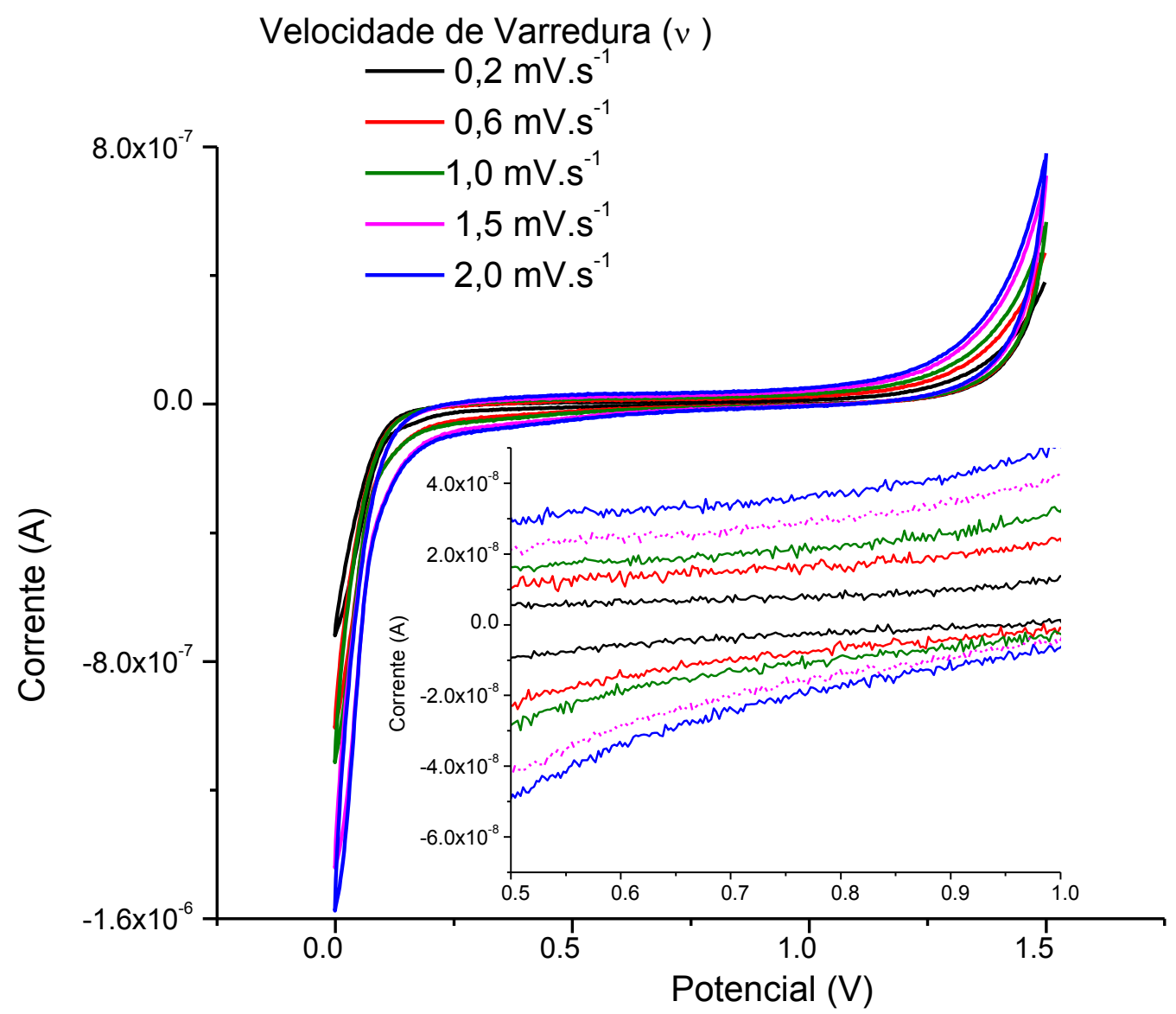

FIGURA 7 - Voltamograma cíclico do eletrodo de Carbono Vítreo, em solução de $\mathrm{KNO}_{3} 0,1 \mathrm{~mol}^{-\mathrm{L}^{-1}}$, velocidade de varredura variando de 0,2 a $2,0 \mathrm{mV} . \mathrm{s}^{-1}$, com ampliação da região da DCE.

Na FIG.8 é mostrado o gráfico da corrente capacitiva estacionária $\left(i_{\mathrm{s}}\right)$ em função da velocidade de varredura $(v)$ para os potenciais de $0,5,0,6$ e $0,7 \vee$ (vs $\mathrm{Ag} / \mathrm{AgCl}$ ). Após o tratamento estatístico dos dados (regressão linear) determinou-se o coeficiente angular da reta $C_{d} S$, segundo Eq.13. 


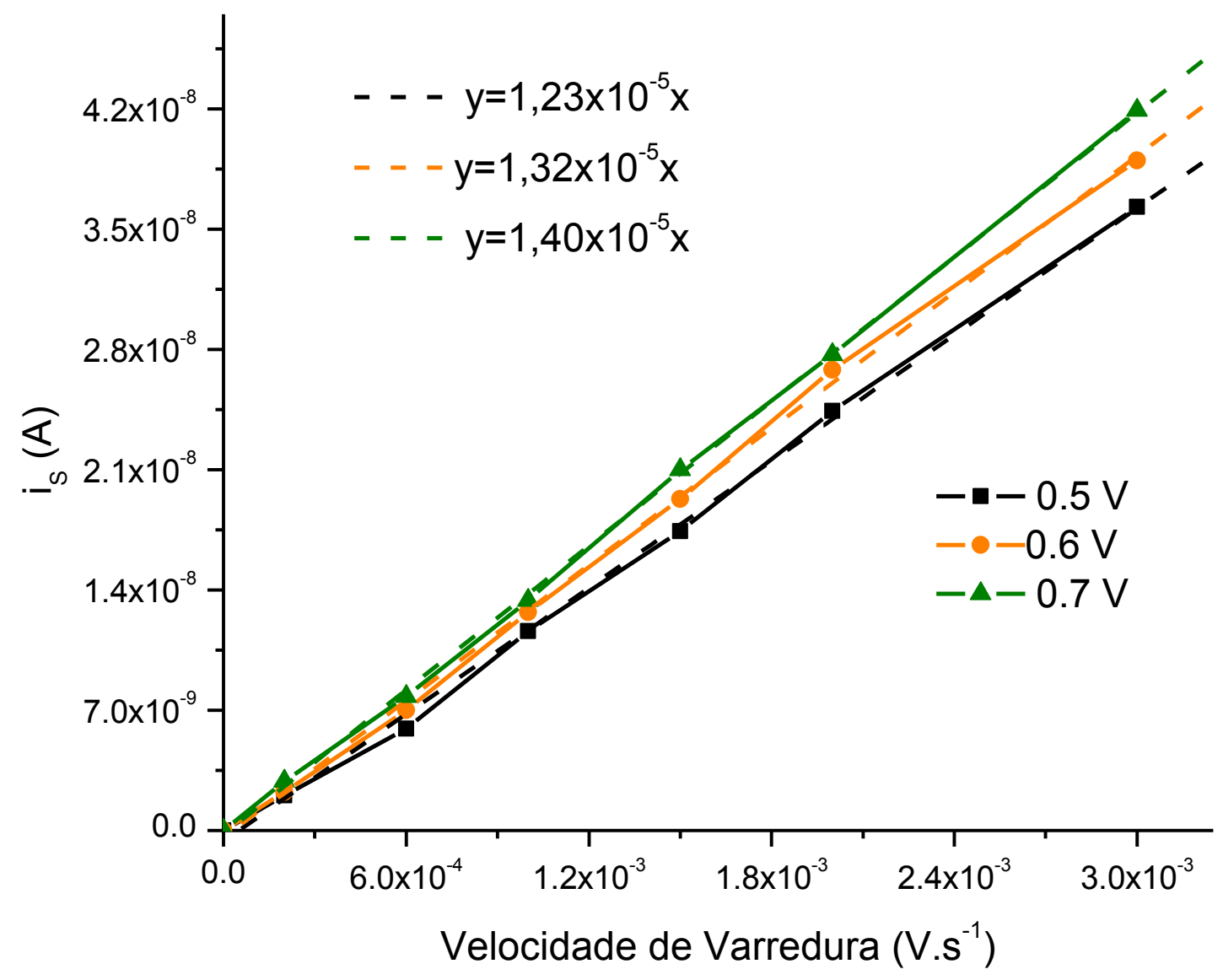

FIGURA 8 - Corrente estacionária versus a velocidade de varredura para os potenciais de $0,5,0,6$ e $0,7 \mathrm{~V}$ (vs $\mathrm{Ag} / \mathrm{AgCl}$ ) e a regressão linear segundo a Eq.13 para o carbono vítreo.

A TAB. 3 mostra os valores obtidos para cada curva da FIG.8 e os seus coeficientes de determinação, $R^{2}$. Os altos valores obtidos para $R^{2}(>99 \%)$ indicam uma forte correlação positiva, ou seja: o modelo linear adotado explica pelo menos $99 \%$ dos dados experimentais, e somente $1 \%$ é atribuída a aleatoriedade. 
TABELA 3 - Valores de $C_{d} S$ para o Carbono Vítreo e seus respectivos coeficientes de determinação.

\begin{tabular}{ccc}
\hline $\begin{array}{c}\text { Potencial } \\
(\mathrm{V})\end{array}$ & $\mathrm{C}_{\mathrm{d}} \mathrm{S}$ & $\begin{array}{c}\text { Coeficiente de } \\
\text { Determinação, } \mathrm{R}^{2}\end{array}$ \\
\hline 0,5 & $(\mathrm{~F})$ & 0,9997 \\
\hline 0,6 & $1,23 \times 10^{-5}$ & 0,9998 \\
\hline 0,7 & $1,32 \times 10^{-5}$ & 0,9987 \\
\hline
\end{tabular}

Calculando-se a média de $\mathrm{C}_{\mathrm{d}} \mathrm{S}$ obtém-se $13,16 \times 10^{-6} \mathrm{~F}$. Utilizando o valor da área geométrica do eletrodo de Carbono Vítreo $\left(3,14 \times 10^{-2} \mathrm{~cm}^{2}\right)$ obtém-se o valor da capacitância pelo método de condutância, ou seja,

$$
\begin{gathered}
C_{d} S=13,16 \mu F \\
C_{d}=\frac{13,16 \times 10^{-6}}{3,14 \times 10^{-2}} \\
C_{d}=419,2 \mu F . \mathrm{cm}^{-2}
\end{gathered}
$$

Por meio da expressão de $i_{S}$ (Eq.13), que relaciona a capacitância com a área do eletrodo, foi possível determinar a capacitância $C_{d}$, para cada um dos potenciais estudados e, finalmente, calcular o valor médio da capacitância.

\subsubsection{Impedância}

$\mathrm{Na}$ FIG.9 são mostrados diagramas de Bode para o Carbono Vítreo obtidos em solução eletrolítica de $\mathrm{KNO}_{3}$ 0,1 mol.L-1 para os potenciais de 0,5, 0,6 e $0,7 \mathrm{~V}$ (vs $\mathrm{Ag} / \mathrm{AgCl}$ ). A escolha desses potenciais é justificada devido a região da DCE estar restrita à esta faixa de potenciais, fato que pode ser verificado por meio dos voltamogramas (FIG.7). 


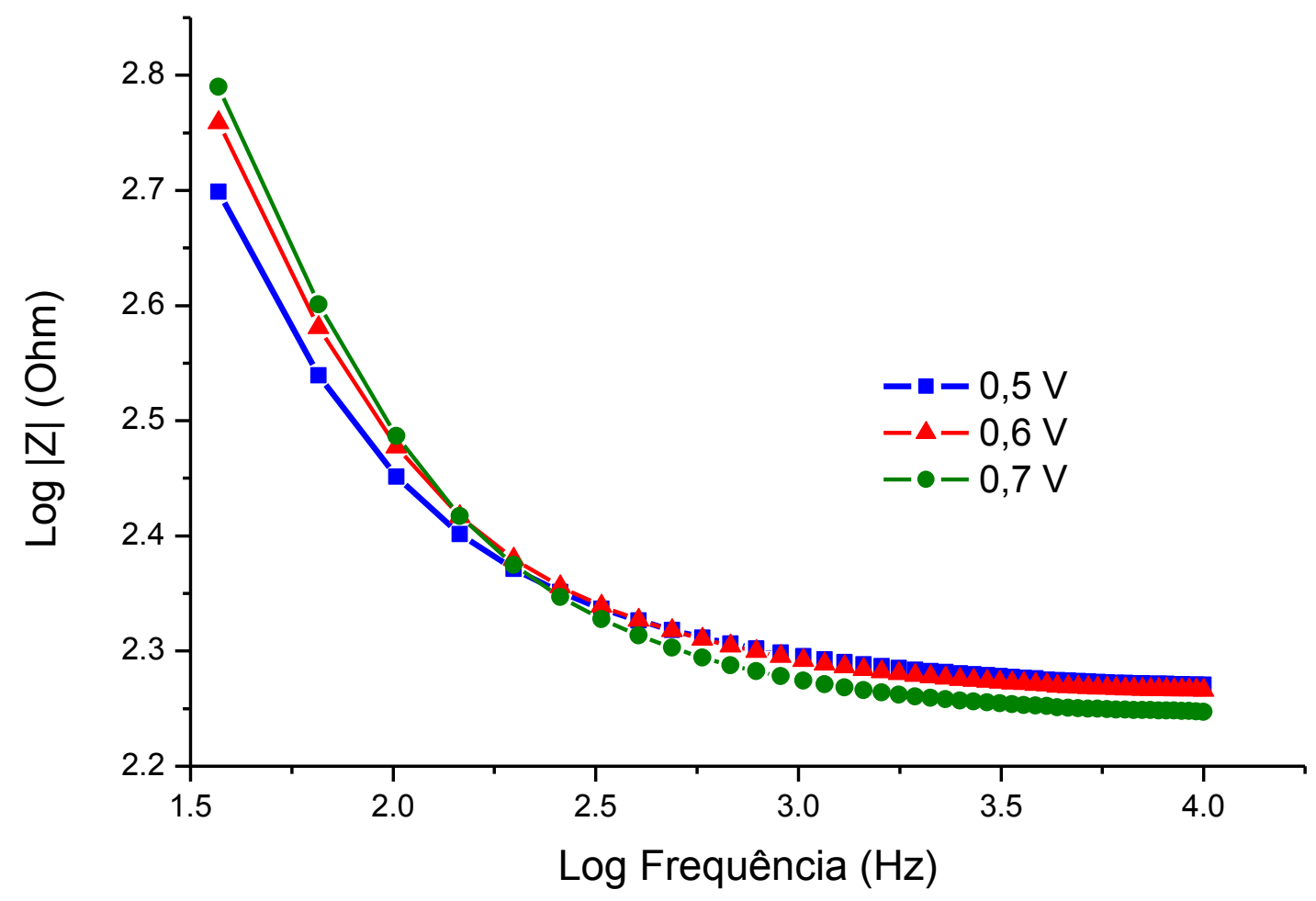

FIGURA 9 - Representação de Bode para o Carbono Vítreo nos potenciais de 0,5, 0,6 e 0,7 V (vs Ag/AgCl).

Na representação de Bode está expresso o valor absoluto da impedância, que como mostrado na Eq.15 é o inverso da capacitância. Repetindo estes cálculos para cada um dos potenciais estudados obtém-se o valor médio de $C_{d}{ }^{[45]}$.

A TAB.4 mostra os valores do módulo da impedância e o valor da capacitância para os potenciais estudados. 
TABELA 4 - Valores do Módulo da Impedância e da Capacitância para o Carbono Vítreo em diferentes potenciais da DCE.

\begin{tabular}{ccc}
\hline Potencial $(\mathrm{V})$ & $|\mathrm{Z}|\left(\mathrm{Ohm} . \mathrm{cm}^{2}\right)$ & $\mathrm{C}_{\mathrm{d}}\left(\mu \mathrm{F} . \mathrm{cm}^{-2}\right)$ \\
\hline 0,5 & $152,64 \times 10^{3}$ & 6,55 \\
\hline 0,6 & $195,08 \times 10^{3}$ & 5,13 \\
\hline 0,7 & $221,26 \times 10^{3}$ & 4,52 \\
\hline
\end{tabular}

A partir dos valores de $\mathrm{C}_{d}$ da TAB.4 obtêm-se $\overline{C_{d}}$, igual a $5,40 \mu \mathrm{F} . \mathrm{cm}^{-2}$. Dividindo este valor pela área do eletrodo de carbono vítreo, temos que:

$$
\overline{C_{d}}=\frac{5,40 \mu F}{3,14 \times 10^{-2}} \approx 172 \mu F . \mathrm{cm}^{-2}
$$

Comparando-se os valores de $\mathrm{C}_{d}$ obtidos de $172 \mu \mathrm{F} . \mathrm{cm}^{-2}$ e $450 \mu \mathrm{F} . \mathrm{cm}^{-2}$ pelos métodos de Impedância e de Condutância, respectivamente, verifica-se que a medida de $\mathrm{C}_{d}$ por Impedância foi aproximadamente três vezes menor do que o valor obtido pelo método voltamétrico e que esse valor se aproxima dos encontrados na literatura ${ }^{[1,55,56]}$. Desta forma, os valores de $C_{d}$ dos demais eletrodos em estudo foram determinados pelo método de Impedância.

Na FIG.10 são apresentas micrografias representativas da superfície do eletrodo de Carbono Vítreo, sendo mostrados os resultados para o estudo da morfologia dessa amostra. É possível ver que não há diferenças significativas relacionadas com a homogeneidade. Este eletrodo foi obtido comercialmente e usado na sua forma original, sem adição de qualquer revestimento. 
a)

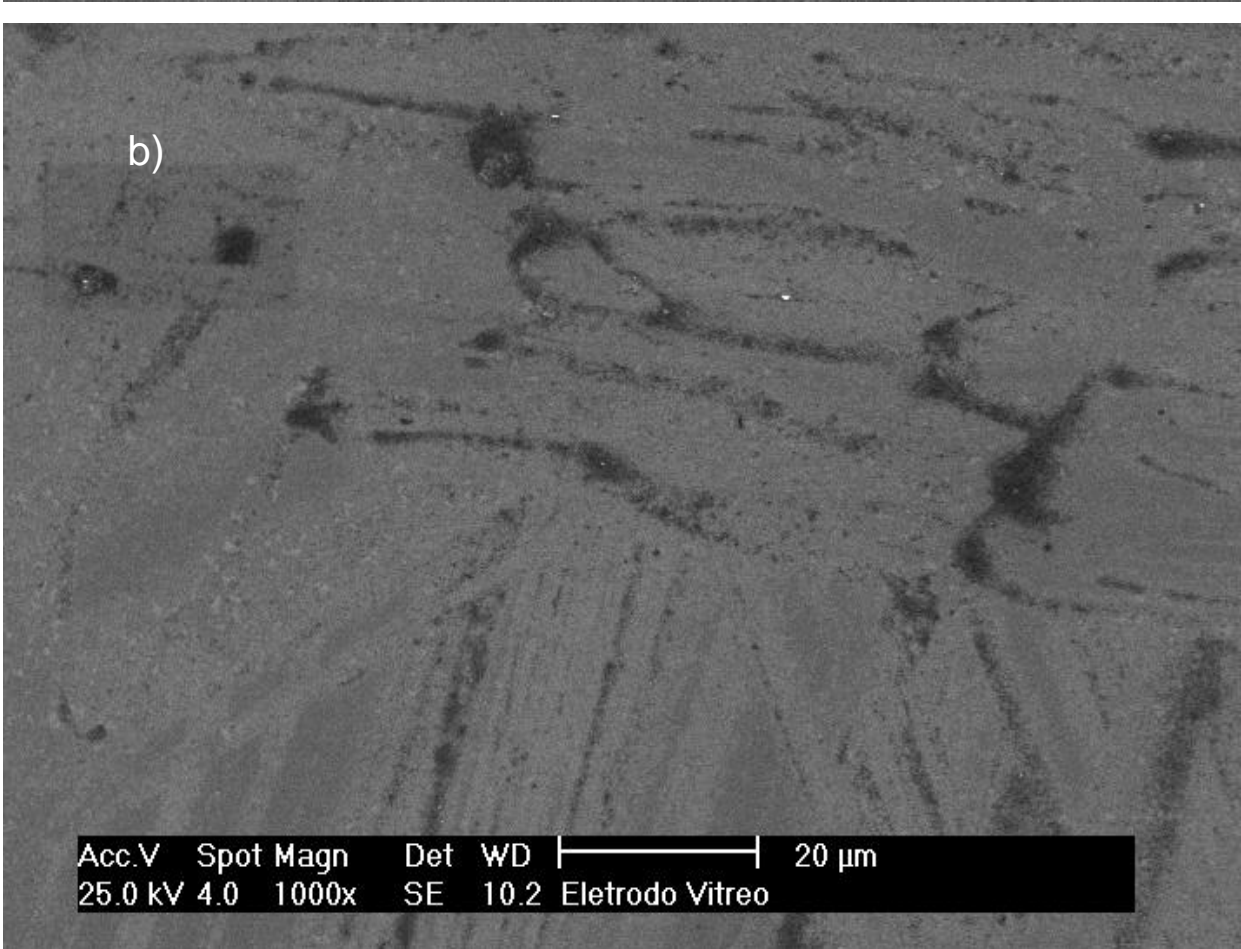

FIGURA 10 - Micrografias obtidas por Microscopia Eletrônica de Varredura (MEV) da superfície do eletrodo de Carbono Vítreo (ECV), a) 500x, b) $1000 x$. 


\subsection{Eletrodos de Troca lônica e de Carbono Poroso}

Para a determinação da área superficial ativa dos eletrodos de troca iônica e carbono poroso todos os procedimentos feitos no eletrodo de carbono vítreo, de (a) até (d), foram realizados nestes eletrodos, adicionando-se duas novas etapas:

f) Determinação do valor médio da capacitância, $\overline{C_{d}}$, na região da DCE por EIE, utilizando o diagrama de Bode.

g) Determinação da área superficial ativa.

\subsubsection{Eletrodo de troca iônica 1 (ETI-1)}

Para o ETI-1 as medidas eletroquímicas foram realizadas de duas maneiras. Primeiro o eletrodo foi envolto com Durepox ${ }^{\circledR}$ para limitar a área exposta ao eletrólito em $1,0 \mathrm{~cm}^{2}$. Depois um segundo eletrodo foi preparado para que a área determinada por VC e EIE pudesse ser comparada com o método de BET. Foi utilizada uma área superficial geométrica do ETI-1 de: $3,1 \mathrm{~cm}^{2}$ com massa de $0,2282 \mathrm{~g}$.

\subsubsection{ETI-1 de 1,0 cm2 de área geométrica}

\subsection{Condutância}

Na FIG.11 são mostrados os voltamogramas para o ETI-1 $\left(1 \mathrm{~cm}^{2}\right)$, que foram realizados em solução eletrolítica de $\mathrm{KNO}_{3}, 0,1$ mol.L-1 e velocidade de varredura de 0,2 a 2,0 mV.s ${ }^{-1}$. Considerando os voltamogramas obtidos, verificou-se que na faixa de potenciais de 0,5 a $1,0 \mathrm{~V}$ (vs $\mathrm{Ag} / \mathrm{AgCl}$ ) localiza-se a região de DCE para as velocidades de varreduras citadas e, portanto, a corrente capacitiva referente a estes potenciais foram utilizadas para os cálculos da área efetiva do ETI-1. Esta 
região foi ampliada para melhor visualização dos valores da corrente utilizada no cálculo de $\mathrm{C}_{d} \mathrm{~S}$.

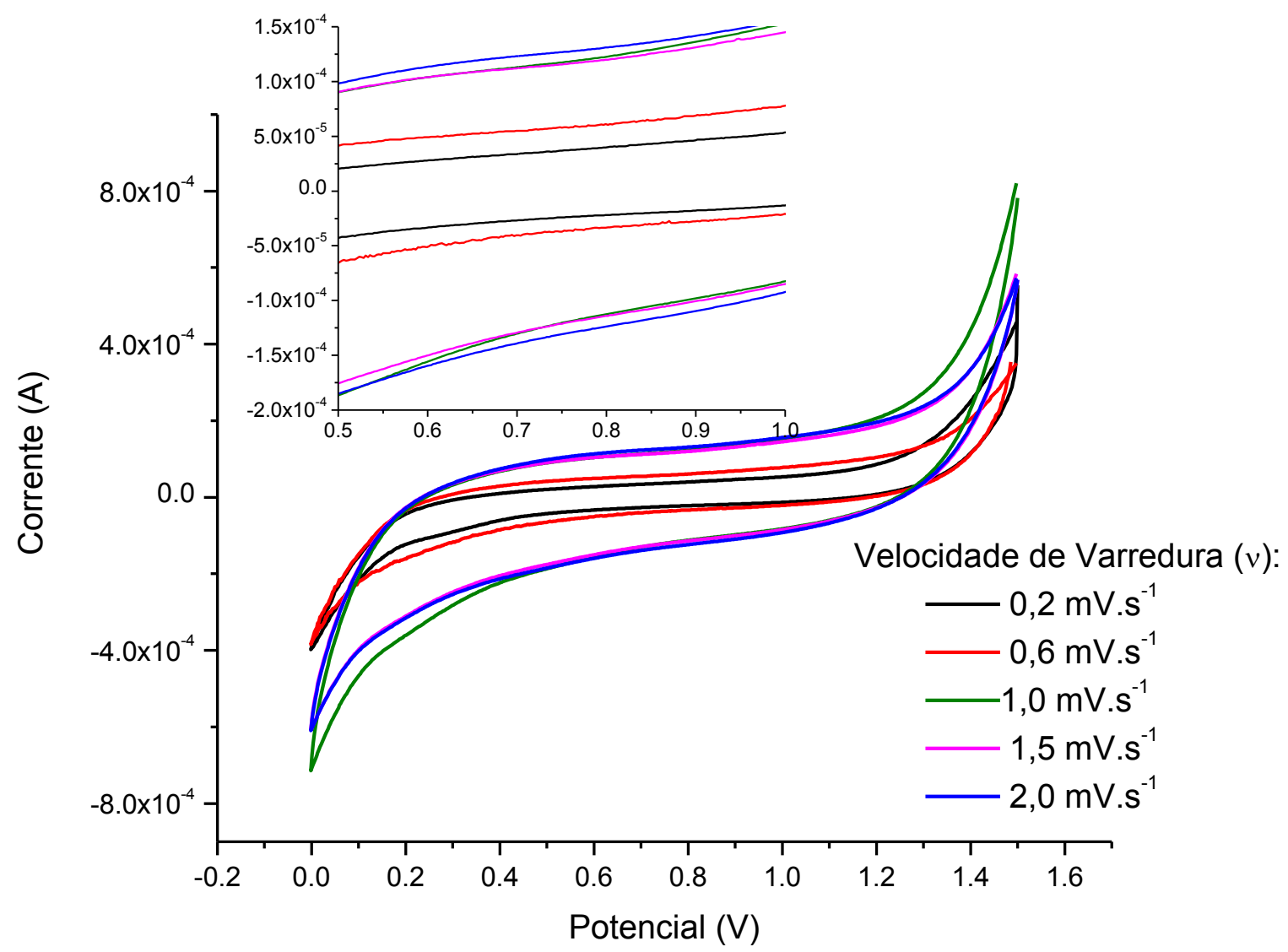

FIGURA 11 - Voltamograma Cíclico do ETI-1 $\left(1 \mathrm{~cm}^{2}\right)$, em solução de $\mathrm{KNO}_{3}, 0,1$ mol. $\mathrm{L}^{-1}$, velocidade de varredura variando 0,2 a $2,0 \mathrm{mV} . \mathrm{s}^{-1}$, com ampliação da região de DCE.

$\mathrm{Na}$ FIG.12 tem-se a corrente capacitiva para o ETI-1 $\left(1 \mathrm{~cm}^{2}\right)$. A corrente que é composta de uma soma apresenta duas contribuições. A primeira contribuição é estacionária (para velocidades de varredura entre 0,2 à $2,0 \mathrm{mV} \cdot \mathrm{s}^{-1}$ ) e obedece a Eq.13, e a segunda refere-se à parte transitória, que decresce exponencialmente com o tempo. 
Consideraram-se os dados experimentais relacionados na curva $i_{C} \times v$, no intervalo de baixas velocidades de varredura, $0,2 \leq v<10 \mathrm{mV} \cdot \mathrm{s}^{-1}$, onde os dados apresentam uma dependência linear (Eq.13). Pode-se, portanto, desconsiderar a região de altas velocidades de varredura, isto é, região que apresenta $v>10 \mathrm{mV} \cdot \mathrm{s}^{-1}$ chamada "região transitória". Dessa forma o intervalo estacionário, com velocidades de varredura $<10 \mathrm{mV} \cdot \mathrm{s}^{-1}$, é o mais apropriado para o cálculo da área superficial ativa, $S$, ficando explícito dessa maneira que apenas a parte linear das curvas de corrente capacitiva é considerada ${ }^{[1]}$.

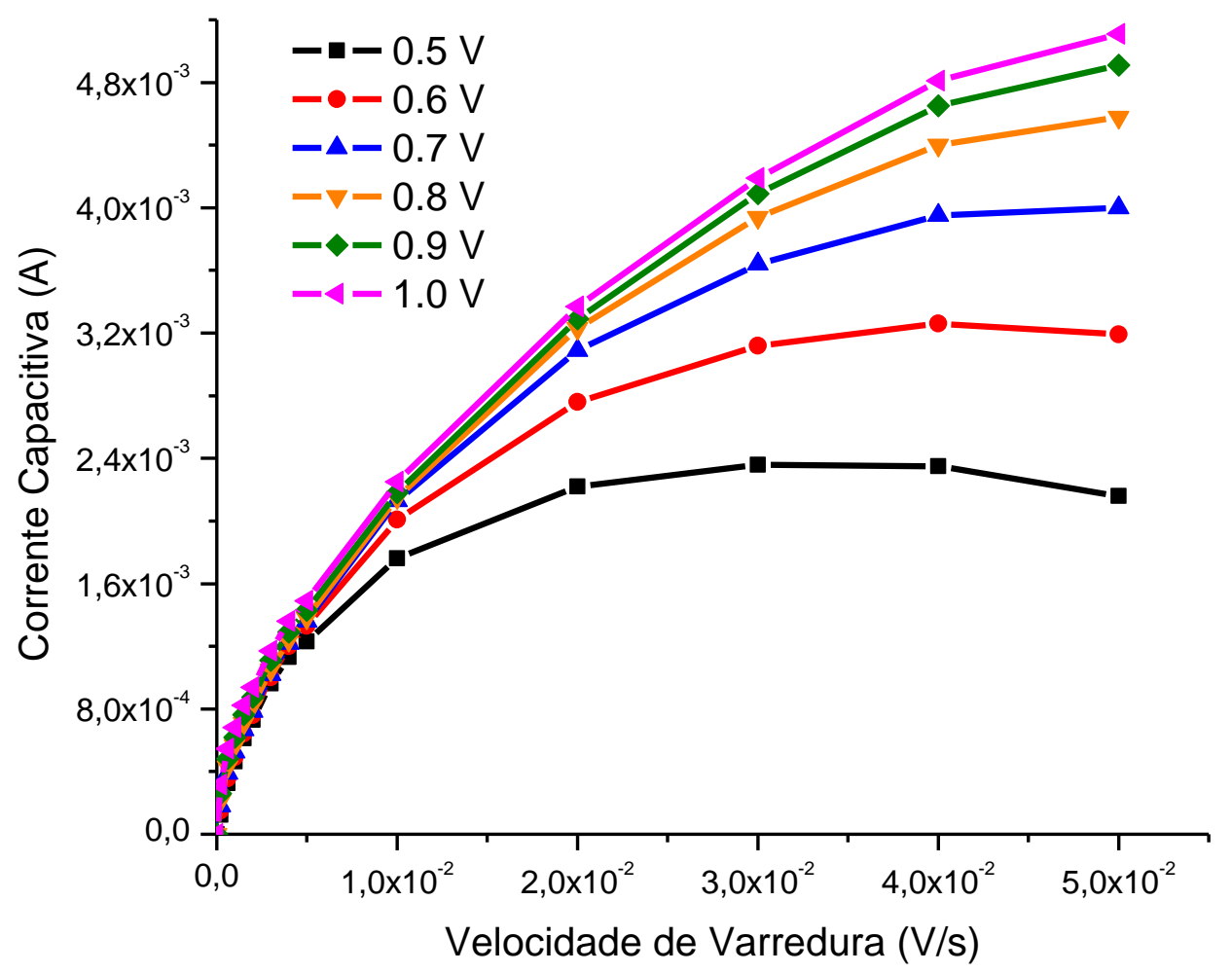

FIGURA 12 - Corrente capacitiva em função da velocidade de varredura para os potenciais de 0,5 a $1,0 \mathrm{~V}$ (vs $\mathrm{Ag} / \mathrm{AgCl}$ ) em solução de $\mathrm{KNO}_{3} \quad 0,1$ mol. $\mathrm{L}^{-1}$, velocidade de varredura variando de 0,2 a $50 \mathrm{mV} . \mathrm{s}^{-1}$, para o ETI-1 $\left(1 \mathrm{~cm}^{2}\right)$. 
Na FIG.13 é mostrada a corrente estacionária ( $\left.i_{s}\right)$ em função da velocidade de varredura $(v)$ para os potenciais de $0,5,0,6$ e $0,7 \mathrm{~V}(\mathrm{vs} \mathrm{Ag} / \mathrm{AgCl})$ para o ETI-1. Foram realizados os ajustes das curvas determinando-se $\mathrm{C}_{d} S$ (coeficiente angular da reta) para cada potencial segundo a Eq.13 e seus valores estão na TAB.5.

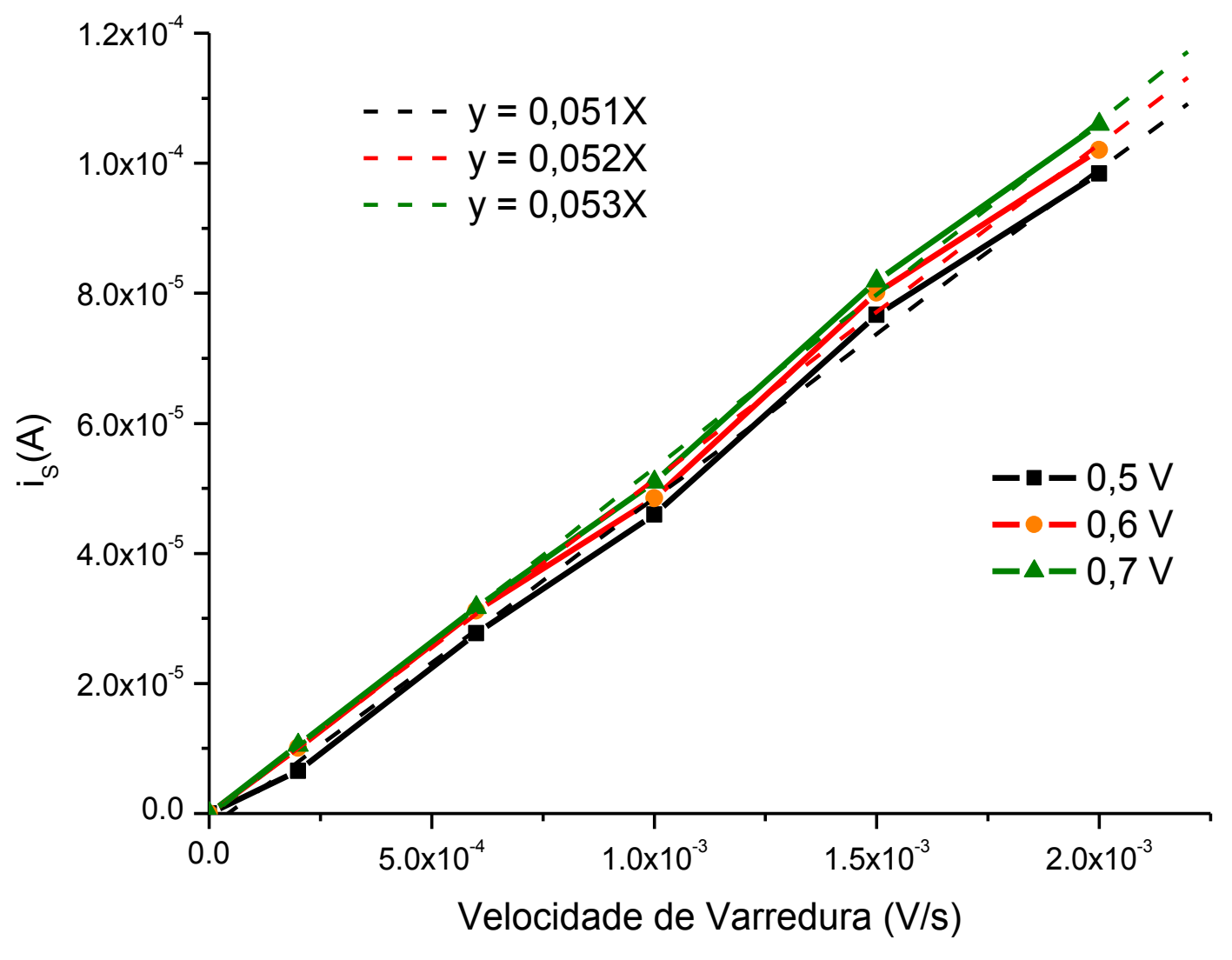

FIGURA 13 - Corrente capacitiva estacionária em função da velocidade de varredura para os potenciais de $0,5,0,6$ e $0,7 \mathrm{~V}$ ( $\mathrm{vs} \mathrm{Ag} / \mathrm{AgCl}$ ) e a regressão linear segundo a Eq. 13, para o ETI-1 $\left(1 \mathrm{~cm}^{2}\right)$. 
A TAB.5 mostra os valores obtidos para cada curva da FIG.13 e os seus respectivos coeficientes de determinação, $R^{2}$.

TABELA 5 - Valores de $C_{d} S$ e seus respectivos coeficientes de determinação para o ETI-1 $\left(1 \mathrm{~cm}^{2}\right)$.

\begin{tabular}{ccc}
\hline $\begin{array}{c}\text { Potencial } \\
(\mathrm{V})\end{array}$ & $\mathrm{C}_{\mathrm{d}} \mathrm{S}$ & $\begin{array}{c}\text { Coeficiente de } \\
\text { Determinação, } \mathrm{R}^{2}\end{array}$ \\
\hline 0,5 & $(\mathrm{~F})$ & 0,998 \\
\hline 0,6 & 0,051 & 0,998 \\
\hline 0,7 & 0,052 & 0,999 \\
\hline
\end{tabular}

Calculando-se a média de $\mathrm{C}_{\mathrm{d}} \mathrm{S}$ obtém-se 0,052 F.

\subsection{Impedância}

Na FIG.14 são mostrados os diagramas de Bode para o ETI-1 $\left(1 \mathrm{~cm}^{2}\right)$. As medidas foram realizadas em solução eletrolítica de $\mathrm{KNO}_{3} \quad 0,1$ mol.L-1 para os potenciais de $0,5,0,6$ e $0,7 \mathrm{~V}$, respectivamente. 


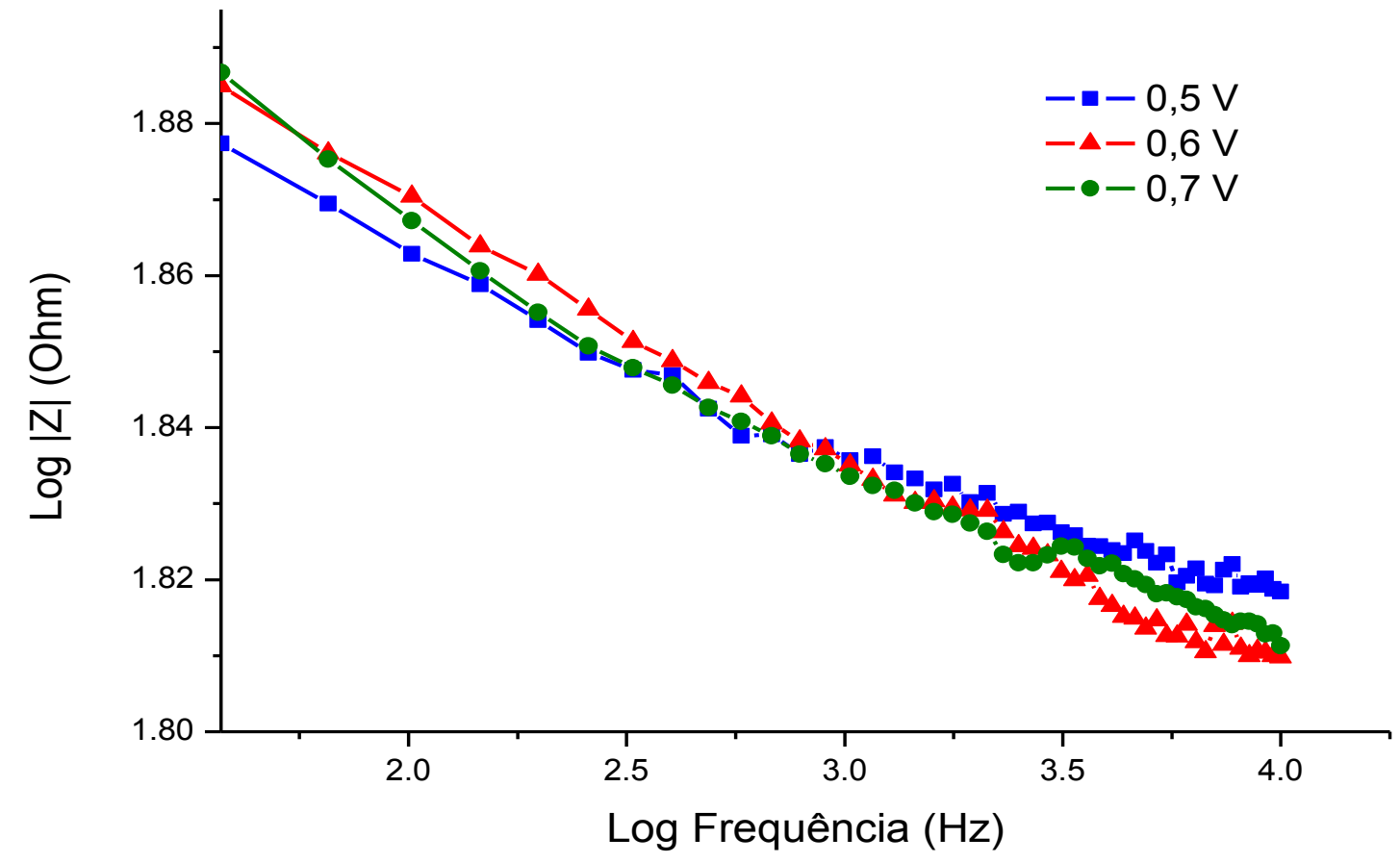

FIGURA 14 - Representação de Bode para ETI-1 $\left(1 \mathrm{~cm}^{2}\right)$ no potencial de 0,5, 0,6 e $0,7 \mathrm{~V}$ (vs $\mathrm{Ag} / \mathrm{AgCl}$ ) em solução de $\mathrm{KNO}_{3}, 0,1 \mathrm{~mol} \cdot \mathrm{L}^{-1}$.

A extrapolação das curvas forneceu o módulo da Impedância (|Z|), como explicitado na Eq.15, obtendo-se o valor médio de $C_{d}$ relativo aos potenciais estudados. A TAB.6 mostra os valores do módulo da Impedância e o valor da capacitância alcançado para os potenciais analisados. 
TABELA 6 - Valores do módulo da impedância e da capacitância para o ETI-1 $\left(1 \mathrm{~cm}^{2}\right)$.

\begin{tabular}{ccc}
\hline $\begin{array}{c}\text { Potencial } \\
(\mathrm{V})\end{array}$ & $\begin{array}{c}|\mathrm{Z}| \\
\left(\mathrm{Ohm} . \mathrm{cm}^{2}\right)\end{array}$ & $\begin{array}{c}\mathrm{C}_{\mathrm{d}} \\
\left(\mathrm{F} . \mathrm{cm}^{-2}\right)\end{array}$ \\
\hline 0,5 & 91,83 & 0,011 \\
\hline 0,6 & 91,17 & 0,011 \\
\hline 0,7 & 100,09 & 0.009 \\
\hline
\end{tabular}

O valor médio de $C_{d}$ foi igual a $0,011 \mathrm{~F}_{\mathrm{cm}} \mathrm{cm}^{-2}$ para o ETI-1 e será usado para calcular a área deste eletrodo utilizando o método de condutância.

Utilizando o valor de $\overline{C_{d}} S$ calculado por condutância e a média da capacitância obtida pelo método de Impedância e isolando a área superficial ativa, S, temos que:

$$
\begin{gathered}
\overline{C_{d} S}=0,052 \mathrm{~F} \\
S=\frac{0,052 \mathrm{~F}}{0,011 \mathrm{~F} \cdot \mathrm{cm}^{-2}} \\
S=4,72 \mathrm{~cm}^{2}
\end{gathered}
$$

O valor alcançado mostra que a área superficial ativa, S, é maior que a área geométrica $\left(1 \mathrm{~cm}^{2}\right)$, logo os materiais condutores contribuem significativamente na determinação da área ativa. A FIG.15 mostra as micrografias representativas da superfície do ETI-1 obtidas por MEV. 

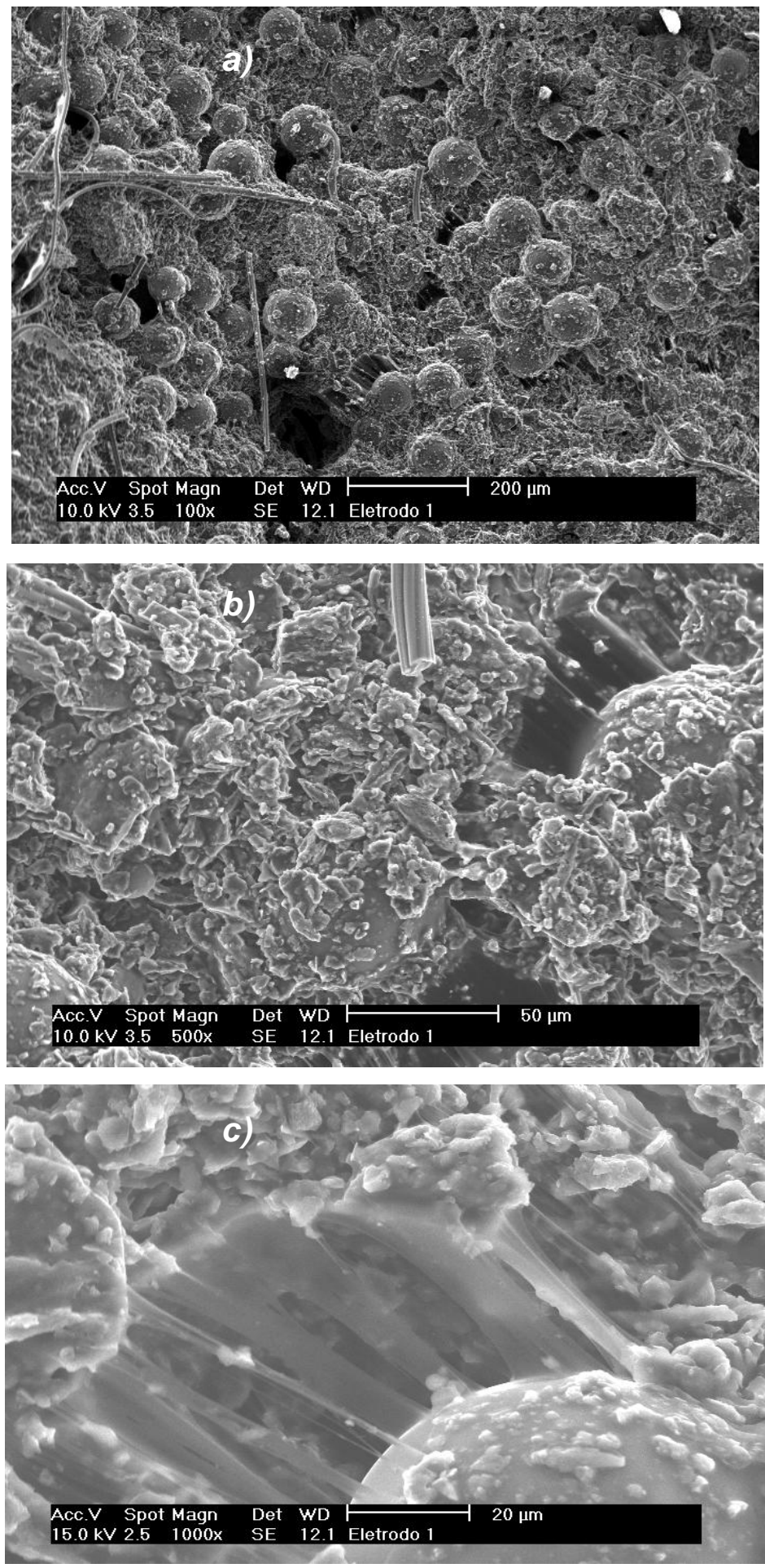

FIGURA 15 - Micrografias obtidas por Microscopia Eletrônica de Varredura (MEV) da superfície do ETI-1 com aumento de: a) 100x, b) 500x e c) $1000 x$. 
A análise da superfície mostra que há diferença morfológica significativa na amostra do ETI-1 $\left(1 \mathrm{~cm}^{2}\right)$ dentro de uma mesma região escolhida: as esferas são a resina e as partículas menores são o carvão e/ou grafite (FIG.15(a)), e as estruturas de geometria na forma de pequenos bastões/filamentos representam a matriz porosa do feltro de carbono (FIG.15(b)).

$\mathrm{Na}$ FIG.15(a) também é possível observar que estes bastonetes arredondados que apresentam partículas (grafite/carvão/aglutinante/resina) não estão bem distribuídas na matriz, provavelmente devido às condições de processamento utilizado, as quais levaram a obtenção de um material não uniforme, com falhas e uma mistura não-homogênea dos componentes da formulação, que é importante, visto que a heterogeneidade afeta as propriedades estudadas.

$\mathrm{Na}$ FIG.15(c) pode-se ver o aglutinante polimérico, ou seja, o material semi-transparente que recobre as partículas de geometria esférica (resina), que por sua vez estão envoltas por particulados de tamanhos variados compostos de carvão/grafite. Esta região está circunscrita por carvão/grafite/resina sugerindo alternância de regiões de condutividade e/ou capacitivas dielétricas.

\subsubsection{ETI-1 de $3,1 \mathrm{~cm}^{2}$ de área geométrica}

\subsection{Condutância}

Na FIG.16 é mostrado o voltamograma cíclico do $\mathrm{ETI}-1\left(3,1 \mathrm{~cm}^{2}\right)$ realizado em solução de $\mathrm{KNO}_{3}$ 0,1 mol. $\mathrm{L}^{-1}$ e velocidades de varredura de 0,2 a 2,0 mV.s $\mathrm{s}^{-1}$. Verificou-se que a região da DCE está entre, 0,5 a 1,0V, que foi utilizada para o cálculo de $C_{d} S$. A ampliação da DCE foi realizada pelos mesmos motivos explanados anteriormente (vide pg.27). 


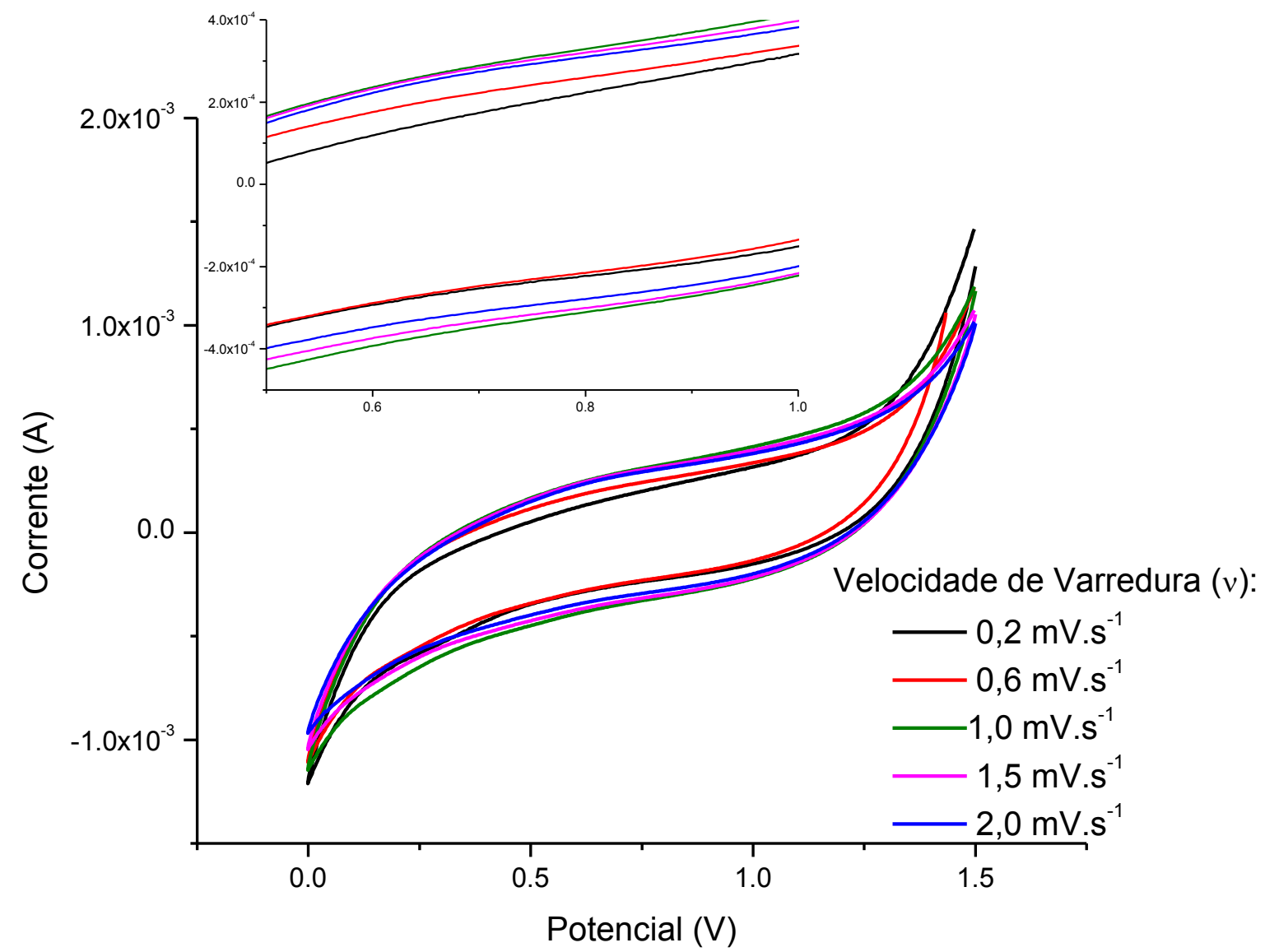

Figura 16 - Voltamograma cíclico do $\operatorname{ETI}-1\left(3,1 \mathrm{~cm}^{2}\right)$, em solução de $\mathrm{KNO}_{3} 0,1$ mol. $\mathrm{L}^{-1}$, velocidade de varredura variando de 0,2 a $2,0 \mathrm{mV} . \mathrm{s}^{-1}$, com ampliação da região da DCE.

$\mathrm{Na}$ FIG.17 tem-se o gráfico da corrente estacionária $\left(i_{\mathrm{s}}\right)$ em função da velocidade de varredura $(v)$ para os potenciais de $0,5,0,6$ e $0,7 \mathrm{~V}(\mathrm{vs} \mathrm{Ag} / \mathrm{AgCl})$ para o ETI-1 $\left(3,1 \mathrm{~cm}^{2}\right)$. O ajuste linear foi feito para cada curva e determinado desta forma $\mathrm{C}_{d} \mathrm{~S}$ (coeficiente angular da reta) para cada potencial segundo a Eq.13. 


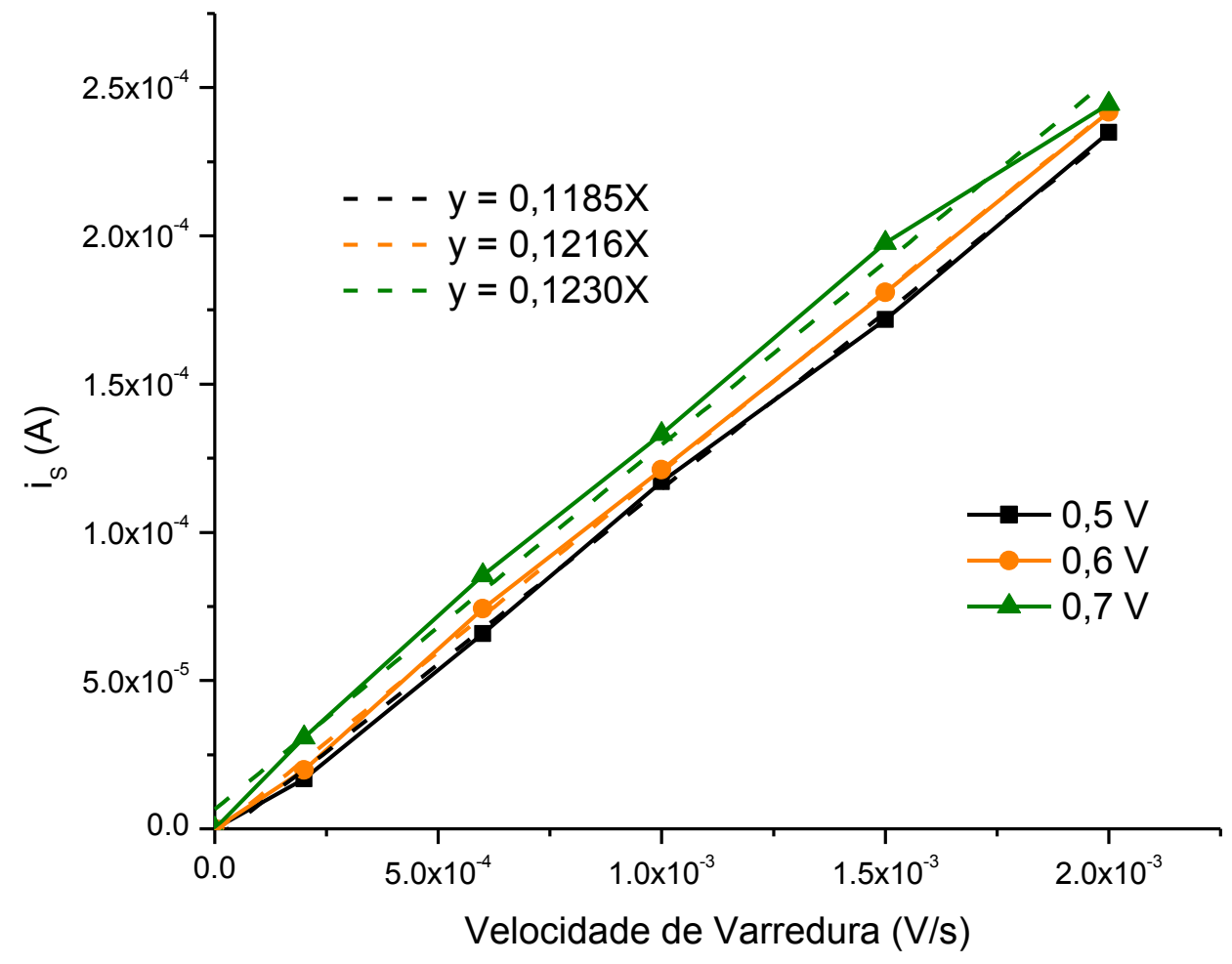

Figura 17 - Corrente estacionária em função da velocidade de varredura para 0 ETI-1 $\left(3,1 \mathrm{~cm}^{2}\right)$ nos potenciais de $0,5,0,6$ e 0,7 V ( vs $\left.\mathrm{Ag} / \mathrm{AgCl}\right)$ e os ajustes das curvas segundo a Eq.13.

Na TAB.7 são mostrados os valores obtidos após o tratamento de dados (FIG.17) e os seus respectivos coeficientes de determinação, $R^{2}$. 
TABELA 7 - Valores de $C_{d} S$ e $\circ$ Coeficiente de Determinação para o ETI-1 $\left(3,1 \mathrm{~cm}^{2}\right)$.

\begin{tabular}{ccc}
\hline $\begin{array}{c}\text { Potencial } \\
(\mathrm{V})\end{array}$ & $\mathrm{C}_{\mathrm{d}} \mathrm{S}$ & $\begin{array}{c}\text { Coeficiente de } \\
\text { Determinação, } \mathrm{R}^{2}\end{array}$ \\
\hline 0,5 & $(\mathrm{~F})$ & 0,9988 \\
\hline 0,6 & 0,1185 & 0,9995 \\
\hline 0,7 & 0,1216 & 0,9947 \\
\hline
\end{tabular}

O valor médio encontrado $C_{d} S$ foi igual a $0,1210 \mathrm{~F}$.

\subsection{Impedância}

Na FIG.18 está representado o diagrama de Bode para o ETI-1 $\left(3,1 \mathrm{~cm}^{2}\right)$ realizado em solução eletrolítica de $\mathrm{KNO}_{3} 0,1$ mol.L $\mathrm{L}^{-1}$ para os potenciais de 0,5, 0,6 e $0,7 \mathrm{~V}(\mathrm{vs} . \mathrm{Ag} / \mathrm{AgCl})$. 


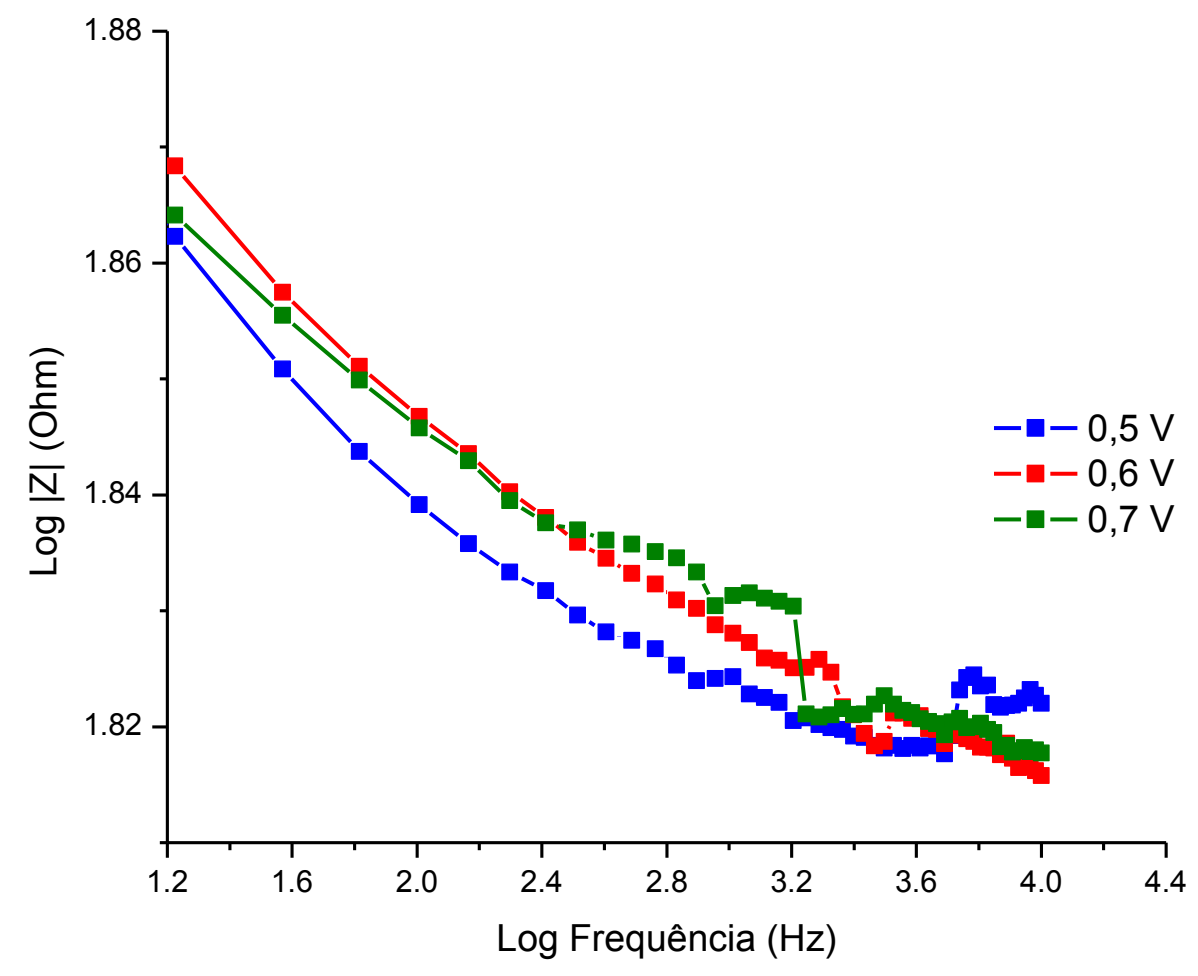

Figura 18 - Representação de Bode para o ETI-1 $\left(3,1 \mathrm{~cm}^{2}\right)$ nos potenciais de 0,5 , $0,6$ e $0,7 \mathrm{~V}$ (vs $\mathrm{Ag} / \mathrm{AgCl})$.

Realizou-se a extrapolação das curvas para a determinação de $|Z|$. Com este valor foi feito o inverso da função logarítmica e o seu valor foi substituído na Eq.15 para encontrar a capacitância, $\mathrm{C}_{\mathrm{d}}$, nos potenciais estudados. Depois calculouse a média de $\mathrm{C}_{\mathrm{d}}$.

A TAB.8 mostra os valores do módulo da impedância e o valor da capacitância alcançado para os potenciais analisados. 
TABELA 8 - Valores do módulo da impedância e da capacitância para o ETI-1 $\left(3,1 \mathrm{~cm}^{2}\right)$.

\begin{tabular}{ccc}
\hline $\begin{array}{c}\text { Potencial } \\
(\mathrm{V})\end{array}$ & $\begin{array}{c}|\mathrm{Z}| \\
\left(\mathrm{ohm} . \mathrm{cm}^{2}\right)\end{array}$ & $\begin{array}{c}\mathrm{C}_{\mathrm{d}} \\
\left(\mathrm{F} . \mathrm{cm}^{-2}\right)\end{array}$ \\
\hline 0,5 & 86,62 & 0,012 \\
\hline 0,6 & 77,85 & 0,013 \\
\hline 0,7 & 76,07 & 0,013 \\
\hline
\end{tabular}

O valor médio da capacitância foi igual a $0,013 F_{. c m}^{2}$ para o ETI-1 $\left(3,1 \mathrm{~cm}^{2}\right)$.

Fazendo os cálculos necessários e isolando $S$, obtém-se:

$$
\begin{gathered}
C_{d} S=0,1210 \\
S=\frac{0,1210 F}{0,013 F \mathrm{Fm}^{-2}} \\
S=9,31 \mathrm{~cm}^{2}
\end{gathered}
$$

\subsubsection{Eletrodo de Troca lônica 2}

Para o ETI-2 não foi possível realizar as medidas de impedância e de condutância. Este eletrodo após 5 minutos imerso na solução de $\mathrm{KNO}_{3}$ desintegrouse provavelmente devido a baixa concentração de aglutinante, necessário para a adesão da resina/carvão/grafite sobre a manta de carbono (vide TAB.2).

A FIG.19 apresenta micrografias representativas da superfície do ETI-2 obtidas por MEV. A análise da superfície mostra que a quantidade de aglutinante não foi suficiente para a penetração da resina/carvão/grafite sobre a matriz (FIG.19(a)). Por estas micrografias (FIG.19(a) e (b)) pode-se ver que não há regiões com o aglutinante aderido às partículas de geometria esférica. 

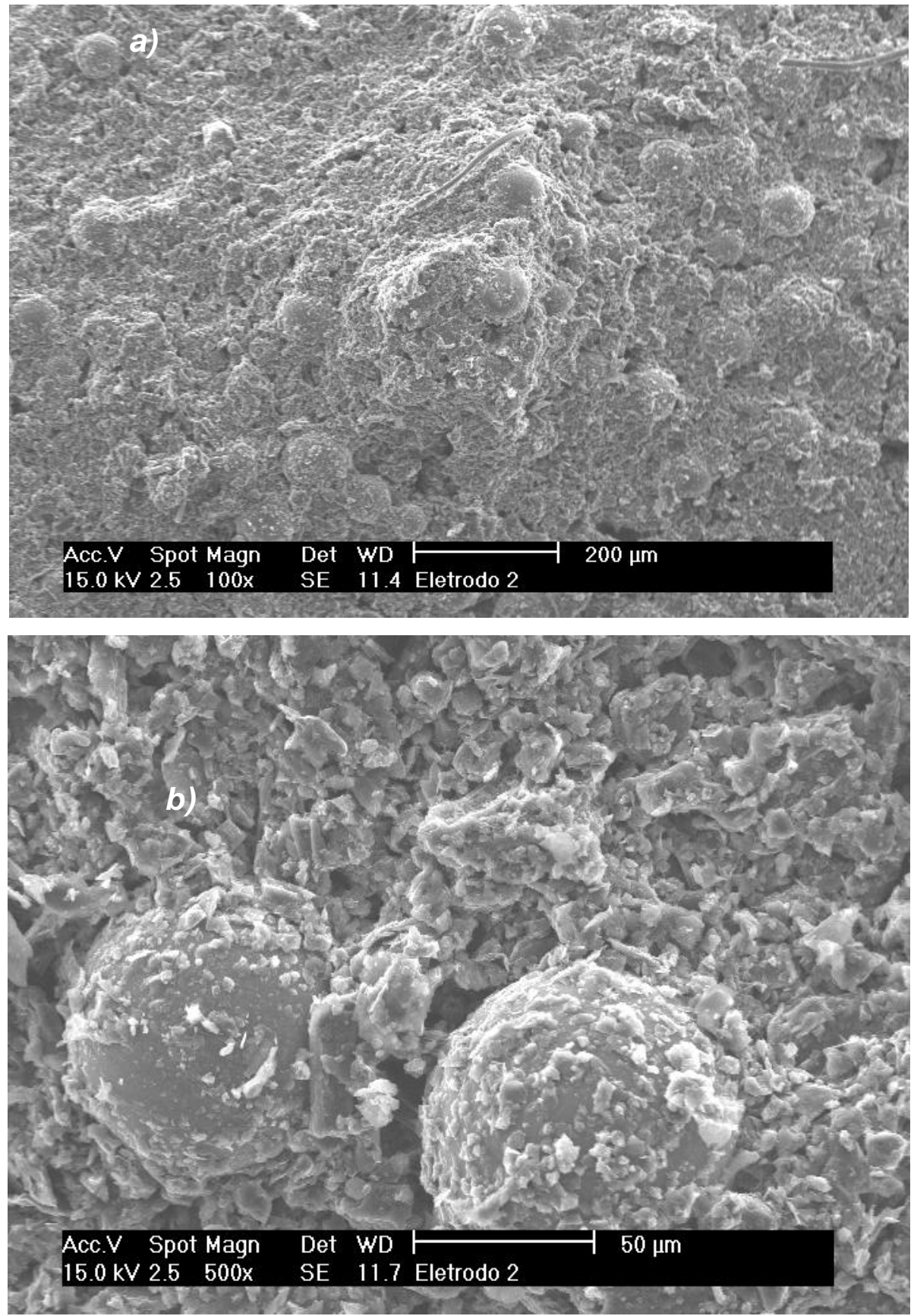

FIGURA 19 - Micrografias obtidas por Microscopia Eletrônica de Varredura (MEV) da superfície de ETI-2 com aumento de: a) 100x, b) 500x. 


\subsubsection{Eletrodo de Troca lônica 3}

\subsubsection{Condutância}

Na FIG.20 é mostrado o voltamograma para o ETI-3. Os mesmos foram obtidos em solução eletrolítica de $\mathrm{KNO}_{3} \quad 0,1 \quad \mathrm{~mol}^{-1} \mathrm{~L}^{-1}$ e velocidade de varredura de 0,2 a 2,0 mV/s. Considerando os voltamogramas, verificou-se que na faixa de potenciais de 0,5 a $1,0 \mathrm{~V}$ (vs $\mathrm{Ag} / \mathrm{AgCl}$ ) localiza-se a região de DCE para as velocidades de varreduras citadas e, portanto, a corrente capacitiva referente a estes potenciais foram utilizadas para os cálculos da área efetiva do ETI-3. A ampliação da DCE foi feita para uma melhor visualização.

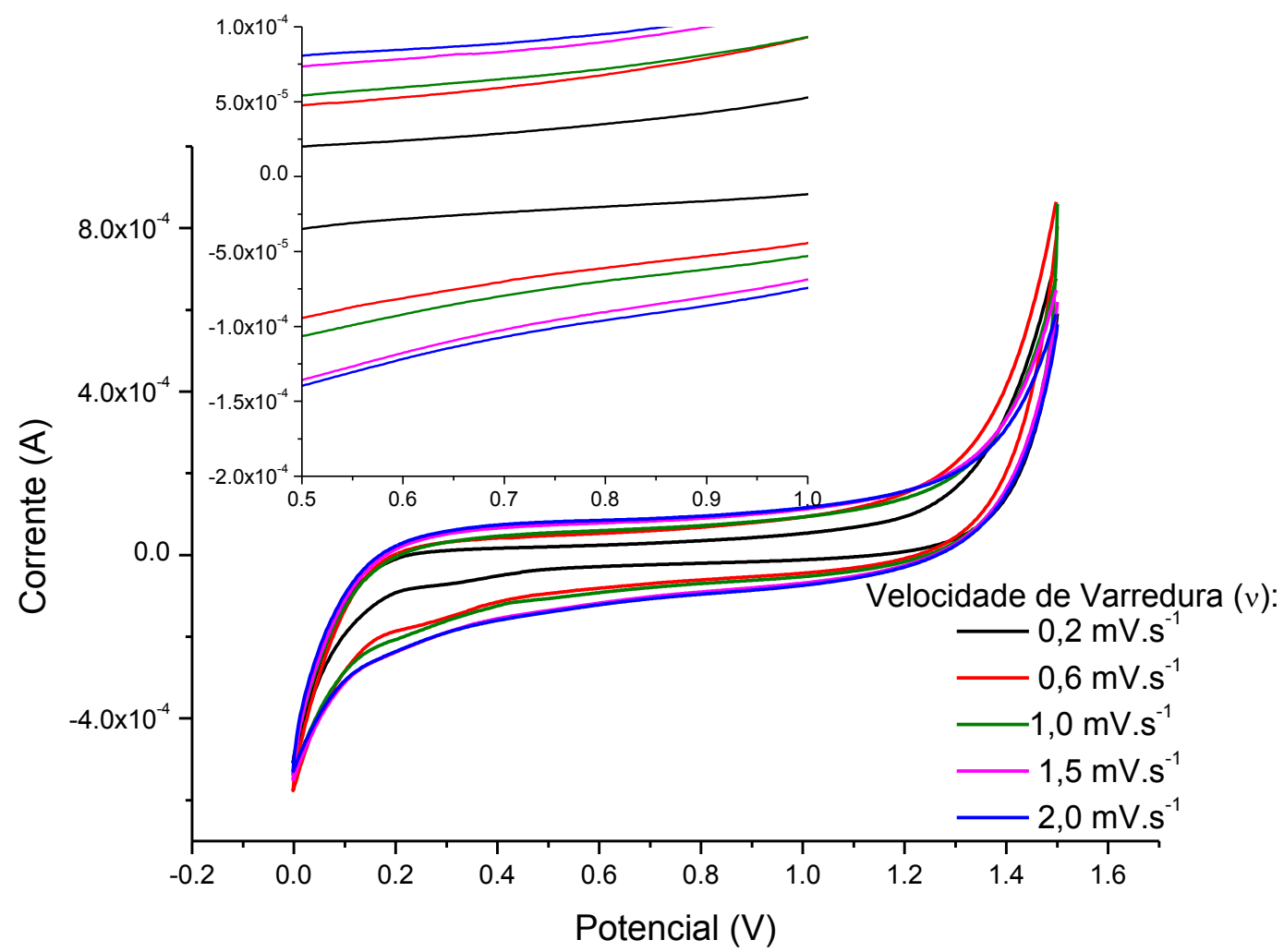

FIGURA 20 - Voltamograma cíclico do ETI-3 em solução de $\mathrm{KNO}_{3} 0,1$ mol.L-1 e velocidade de varredura variando de 0,2 a $2,0 \mathrm{mV} . \mathrm{s}^{-1}$ 
Na FIG.21 é mostrado o gráfico da corrente estacionária ( $\mathrm{i}_{\mathrm{s}}$ ) em função da velocidade de varredura $(v)$ para os potenciais de $0,5,0,6$ e $0,7 \vee$ (vs $\mathrm{Ag} / \mathrm{AgCl}$ ) para o ETI-3. Foram realizados os ajustes das curvas onde foi determinado $\mathrm{C}_{d} \mathrm{~S}$ (coeficiente angular da reta) para cada potencial segundo a Eq.13.

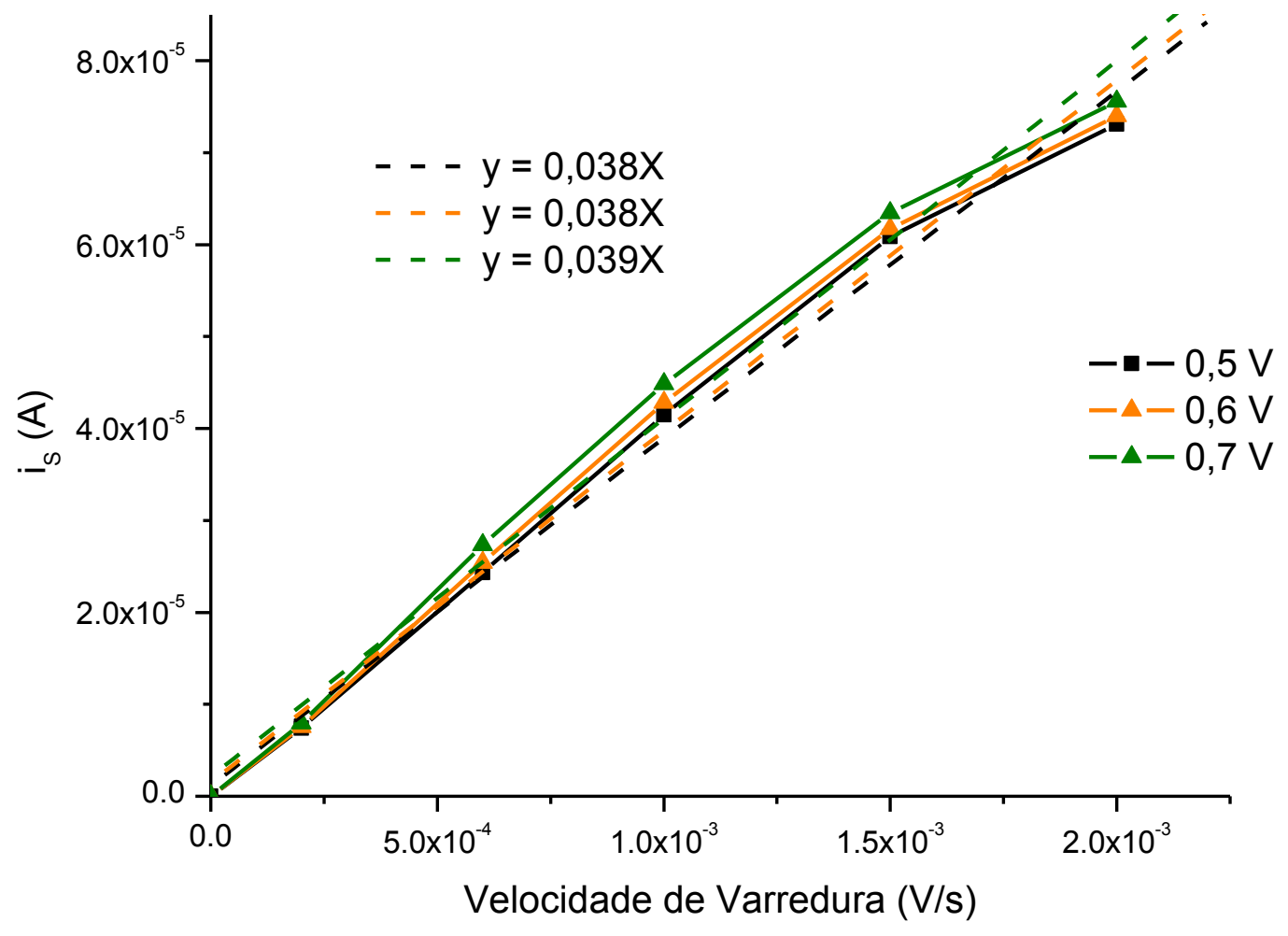

FIGURA 21 - Corrente estacionária em função da velocidade de varredura para os potenciais de $0,5,0,6$ e $0,7 \mathrm{~V}$ (vs $\mathrm{Ag} / \mathrm{AgCl}$ ) e a regressão linear segundo a Eq.13, para o ETI-3

A TAB.9 mostra os valores obtidos para cada curva da FIG. 21 e os seus respectivos coeficientes de determinação, $R^{2}$. 
TABELA 9 - Valores de $C_{d} S$ e seus respectivos Coeficiente de Determinação para o ETI-3.

\begin{tabular}{ccc}
\hline $\begin{array}{c}\text { Potencial } \\
(\mathrm{V})\end{array}$ & $\mathrm{C}_{\mathrm{d}} \mathrm{S}$ & $\begin{array}{c}\text { Coeficiente de } \\
\text { Determinação, } \mathrm{R}^{2}\end{array}$ \\
\hline 0,5 & $(\mathrm{~F})$ & 0,996 \\
\hline 0,6 & 0,038 & 0,995 \\
\hline 0,7 & 0,038 & 0,994 \\
\hline
\end{tabular}

Calculando-se a média de $\mathrm{C}_{\mathrm{d}} \mathrm{S}$ obtém-se 0,038 F.

\subsubsection{Impedância}

Na FIG.22 são mostrados os diagramas de Bode para o ETI-3. As medidas foram obtidas em solução eletrolítica de $\mathrm{KNO}_{3} \quad 0,1 \mathrm{~mol} \cdot \mathrm{L}^{-1}$ para os potenciais de 0,5, 0,6 e 0,7 V (vs. Ag/AgCl).

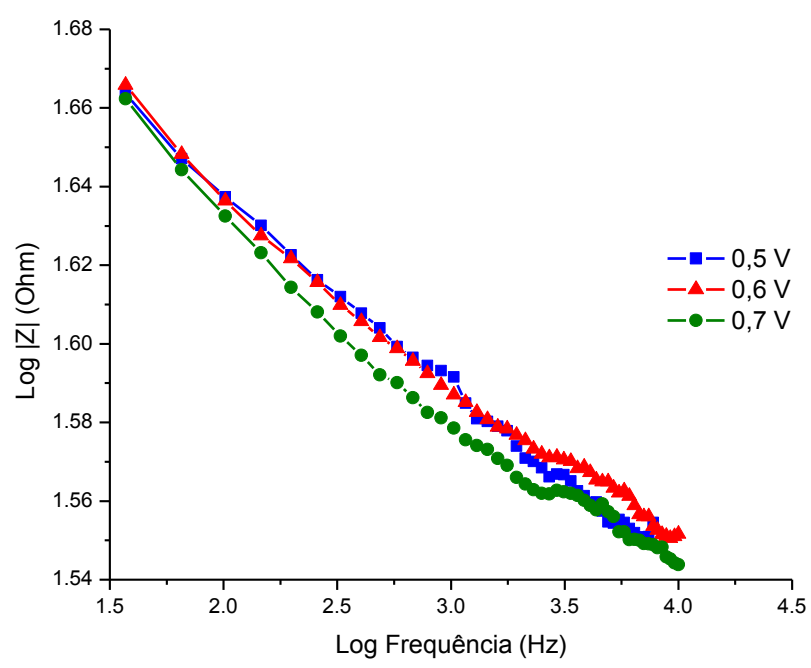

FIGURA 22 - Representação de Bode para o ETI-3 nos potenciais de 0,5, 0,6 e 0,7 V (vs. Ag/AgCl).

Com a extrapolação das curvas determinou-se $|Z|$ e usando a Eq. 15 obteve-se o valor médio de $C_{d}$, relativo aos potenciais estudados. A TAB.10 
mostra os valores do módulo da Impedância e o valor da capacitância alcançado para os potenciais analisados.

TABELA 10 - Valores do módulo da impedância e da capacitância para o ETI3.

\begin{tabular}{ccc}
\hline $\begin{array}{c}\text { Potencial } \\
(\mathrm{V})\end{array}$ & $\begin{array}{c}|\mathrm{Z}| \\
\left(\mathrm{ohm} . \mathrm{cm}^{2}\right)\end{array}$ & $\begin{array}{c}\mathrm{C}_{\mathrm{d}} \\
\left(\mathrm{F} . \mathrm{cm}^{-2}\right)\end{array}$ \\
\hline 0,5 & 45,14 & 0,022 \\
\hline 0,6 & 46,13 & 0,022 \\
\hline 0,7 & 46,03 & 0,022 \\
\hline
\end{tabular}

O valor médio de $\mathrm{C}_{d}$ foi igual a 0,022 $\mathrm{F} . \mathrm{cm}^{-2}$ para o ETI-3. Este valor será usado para calcular a área deste eletrodo utilizando o método de condutância.

Com o valor médio de $\mathrm{C}_{\mathrm{d}} \mathrm{S}$ e da capacitância obtido pelo método da impedância obtém-se a área superficial ativa para este eletrodo:

$$
\begin{gathered}
C_{d} S=0,038 F \\
S=\frac{0,038 F}{0,022 F . \mathrm{cm}^{-2}} \\
S=1,73 \mathrm{~cm}^{2}
\end{gathered}
$$

Este valor alcançado mostra que a área superficial ativa, $\mathrm{S}$, é maior que a área geométrica $\left(1 \mathrm{~cm}^{2}\right)$ logo os materiais condutores contribuem significativamente na determinação da área ativa, e o aumento do aglutinante na composição do eletrodo implica no valor de área obtida, sendo menor que a área obtida para o ETI-1.

Na FIG.23 são apresentadas micrografias representativas da superfície do ETI-3, obtidas por MEV para o estudo da morfologia da amostra. 

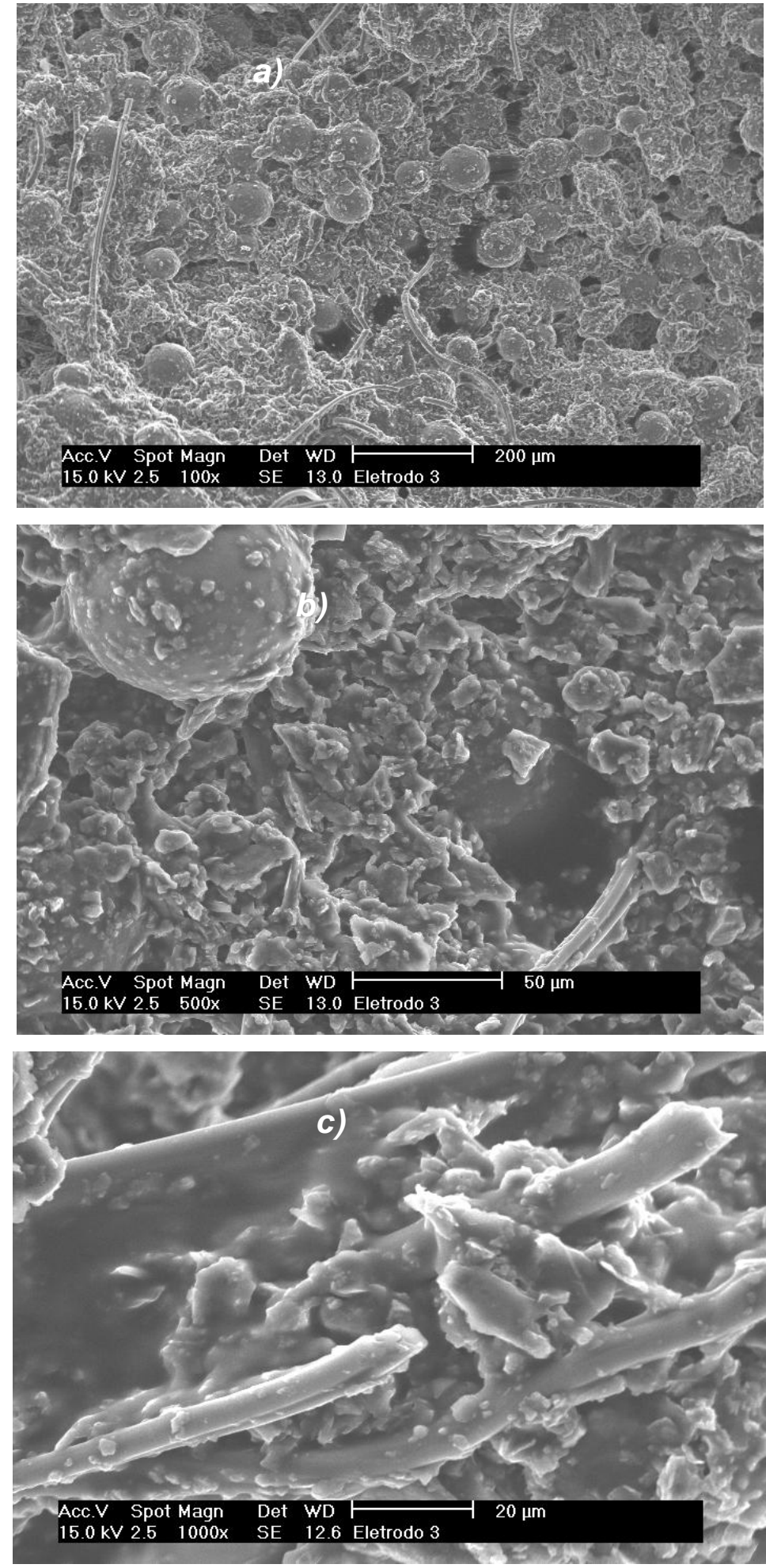

FIGURA 23 - Micrografias obtidas por Microscopia Eletrônica de Varredura (MEV) da superfície do ETI-3 com aumento de: a) 100x, b) 500x, c) $1000 x$. 
A análise da superfície demonstra que há diferença morfológica significativa na amostra do ETI-3 dentro de uma mesma região escolhida: as esferas são a resina, as partículas menores são o carvão e/ou grafite e as estruturas de geometria na forma de pequenos bastões são a matriz porosa de feltro de carbono (FIG.23(a)).

Nas imagens (FIG.23 (b) e (c)) é possível observar que o feltro de carbono (bastonetes) está parcialmente coberto com as partículas de grafite/carvão/aglutinante/resina, provavelmente devido às condições de processamento utilizado, as quais levaram à obtenção de um material não uniforme, com falhas, e uma mistura não-homogênea dos componentes da formulação, etapa esta muito importante, visto que a heterogeneidade afeta as propriedades estudadas. Portanto, as partículas de grafite/carvão/resina não estão bem distribuídas na matriz.

\subsubsection{Eletrodo de Troca lônica 4}

\subsubsection{Condutância}

Na FIG.24 é mostrado o voltamograma para o ETI-4 os mesmos foram realizados em solução eletrolítica de $\mathrm{KNO}_{3}, 0,1$ mol.L-1 e velocidade de varredura de 0,2 a 2,0 mV.s ${ }^{-1}$. Considerando os voltamogramas obtidos, verificou-se que na faixa de potenciais de 0,5 a $1,0 \mathrm{~V}$ (vs $\mathrm{Ag} / \mathrm{AgCl}$ ) localiza-se a região de DCE para as velocidades de varreduras citadas e, portanto, a corrente capacitiva referente a estes potenciais foram utilizadas para os cálculos da área efetiva do ETI-4. A ampliação da DCE foi feita para uma melhor visualização da região. 


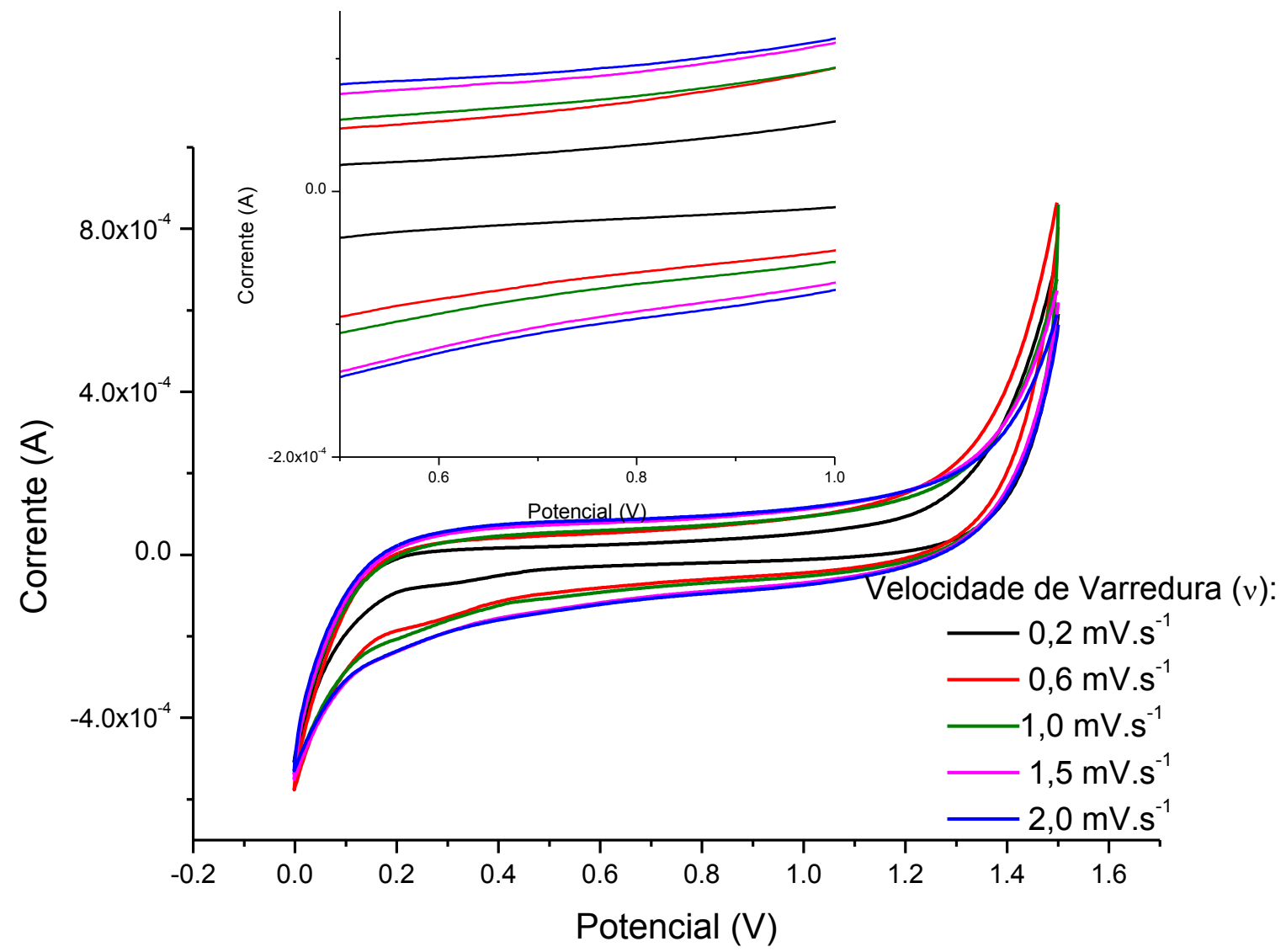

FIGURA 24 - Voltamograma cíclico do ETI- 4 em solução de $\mathrm{KNO}_{3}$ 0,1 $\mathrm{mol}^{-\mathrm{L}^{-1}}$, velocidade de varredura de 0,2 a $2,0 \mathrm{mV} . \mathrm{s}^{-1}$, com ampliação da região de DCE.

Na FIG.25 é mostrado o gráfico da corrente estacionária (i $\left.i_{s}\right)$ em função da velocidade de varredura $(v)$ para os potenciais de 0,5, 0,6 e 0,7 V (vs $\mathrm{Ag} / \mathrm{AgCl}$ ) para o $\mathrm{ETI}-4$. Foram realizados os ajustes das curvas onde foi determinado $\mathrm{C}_{d} \mathrm{~S}$ (coeficiente angular da reta) para cada potencial segundo a Eq.13. 


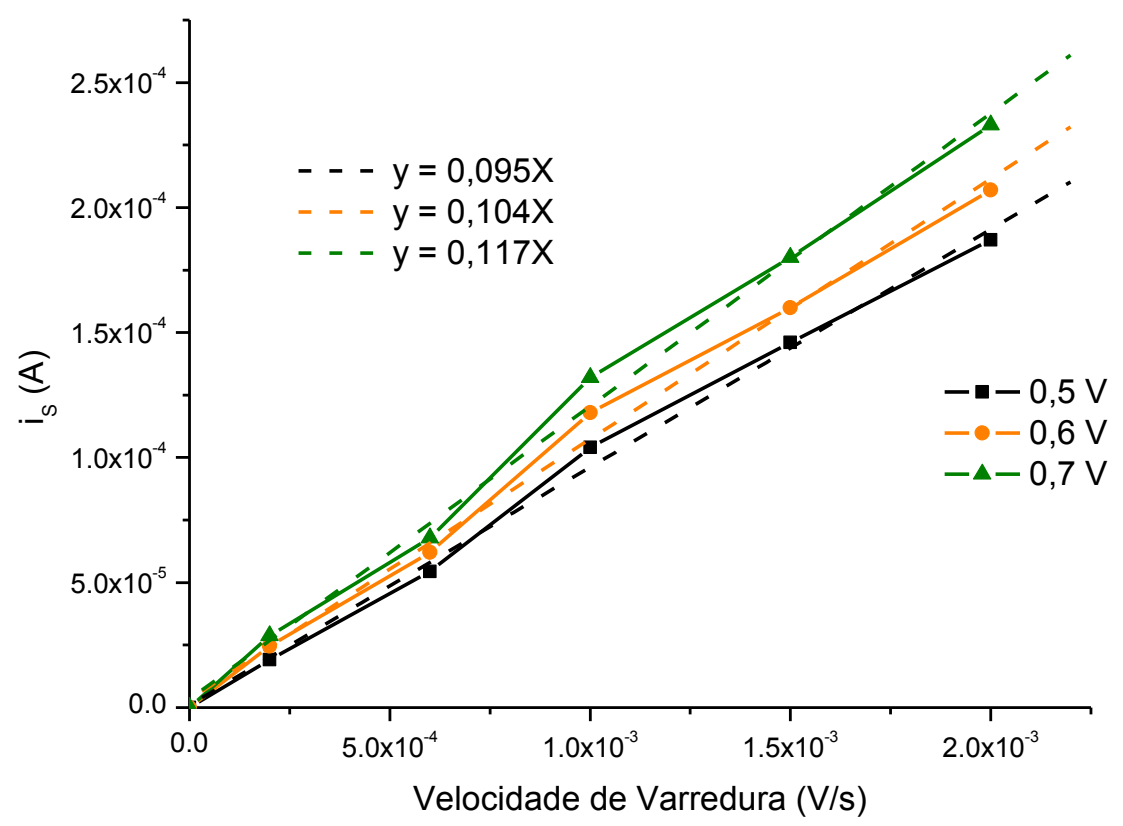

Figura 25 - Corrente estacionária em função da velocidade de varredura para os potenciais de $0,5,0,6$ e $0,7 \mathrm{~V}$ (vs $\mathrm{Ag} / \mathrm{AgCl}$ ) e a regressão linear segundo a Eq.13 para o ETI-4.

$\mathrm{Na}$ TAB.11 pode-se verificar os valores obtidos para cada curva da FIG.25 e os seus respectivos coeficientes de determinação, $R^{2}$.

Tabela 11 - Valores de $C_{d} S$ e do coeficiente de determinação para o ETI-4.

\begin{tabular}{ccc}
\hline $\begin{array}{c}\text { Potencial } \\
(\mathrm{V})\end{array}$ & $\begin{array}{c}\mathrm{C}_{\mathrm{d}} \mathrm{S} \\
(\mathrm{F})\end{array}$ & $\begin{array}{c}\text { Coeficiente de } \\
\text { Determinação, } \mathrm{R}^{2}\end{array}$ \\
\hline 0,5 & 0,095 & 0,998 \\
\hline 0,6 & 0,104 & 0,997 \\
\hline 0,7 & 0,117 & 0,997 \\
\hline
\end{tabular}

O valor médio de $\mathrm{C}_{\mathrm{d}} \mathrm{S}$ é $0,105 \mathrm{~F}$. 


\subsubsection{Impedância}

Na FIG.26 são mostrados os diagramas de Bode para o ETI-4. As medidas foram realizadas em solução eletrolítica de $\mathrm{KNO}_{3} \quad 0,1$ mol.L-1 para os potenciais de $0,5,0,6$ e $0,7 \mathrm{~V}$ (vs. Ag/AgCl).

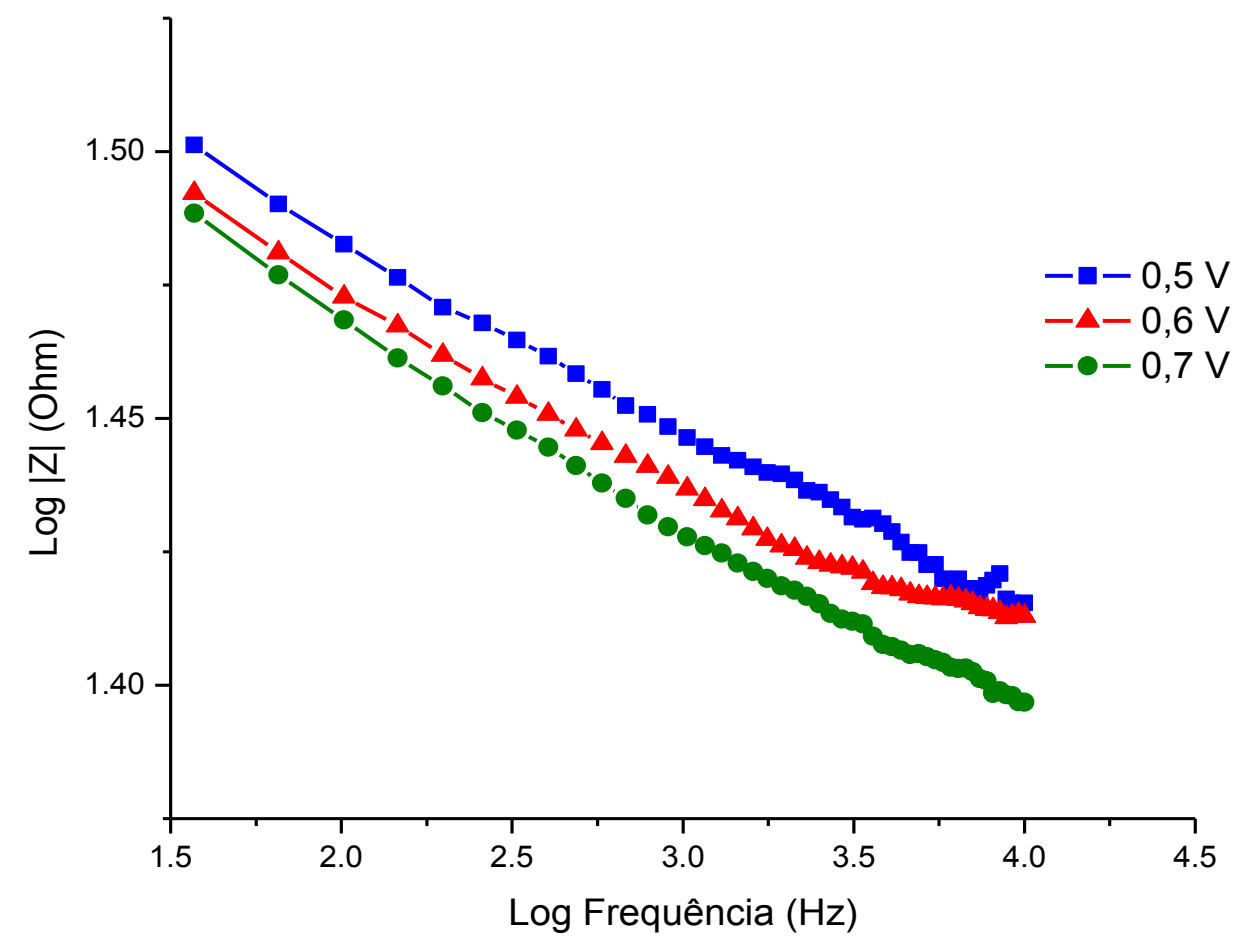

FIGURA 26 - Representação de Bode para o ETI-4 nos potenciais de 0,5, 0,6 e 0,7 V (vs. Ag/AgCl).

Com a extrapolação das curvas determinou-se $|Z|$ e usando a Eq.15 obteve-se o valor médio de $C_{d}$, relativo aos potenciais estudados. A TAB.12 mostra os valores do módulo da impedância e o valor da capacitância alcançado para os potenciais analisados. 
TABELA 12 - Valores do módulo da impedância e da capacitância para o ETI4.

\begin{tabular}{ccc}
\hline $\begin{array}{c}\text { Potencial } \\
(\mathrm{V})\end{array}$ & $\begin{array}{c}|\mathrm{Z}| \\
(\mathrm{ohm})\end{array}$ & $\begin{array}{c}\mathrm{C}_{\mathrm{d}} \\
\left(\mathrm{F} . \mathrm{cm}^{-2}\right)\end{array}$ \\
\hline 0,5 & 31,59 & 0,032 \\
\hline 0,6 & 31,19 & 0,032 \\
\hline 0,7 & 30,82 & 0,032 \\
\hline
\end{tabular}

A média de $\mathrm{C}_{\mathrm{d}}$ foi igual a $0,032 \mathrm{~F} . \mathrm{cm}^{-2}$ para o ETI-4.

Utilizando a média da capacitância calculada pelo método de impedância e isolando a área superficial ativa, $\mathrm{S}$, temos que:

$$
\begin{gathered}
C_{d} S=0,105 F \\
S=\frac{0,105 F}{0,032 F \cdot \mathrm{cm}^{-2}} \\
S=3,28 \mathrm{~cm}^{2}
\end{gathered}
$$

O valor da área superficial ativa, $S$, foi maior que a área geométrica $\left(1 \mathrm{~cm}^{2}\right)$ indicando que o aumento da quantidade de carvão e a diminuição de aglutinante na composição do eletrodo implicam no valor de área ativa alcançado, análise obtida através da comparação do resultado de área do ETI-3.

A FIG.27 apresenta micrografias representativas da superfície do ETI-4 obtidas por MEV. Nas imagens é possível fazer a mesma análise realizada para os ETI-1 e ETI-3, ou seja, as condições de processamento utilizado levaram a obtenção de um material não uniforme, com falhas, e uma mistura nãohomogênea dos componentes da formulação. 

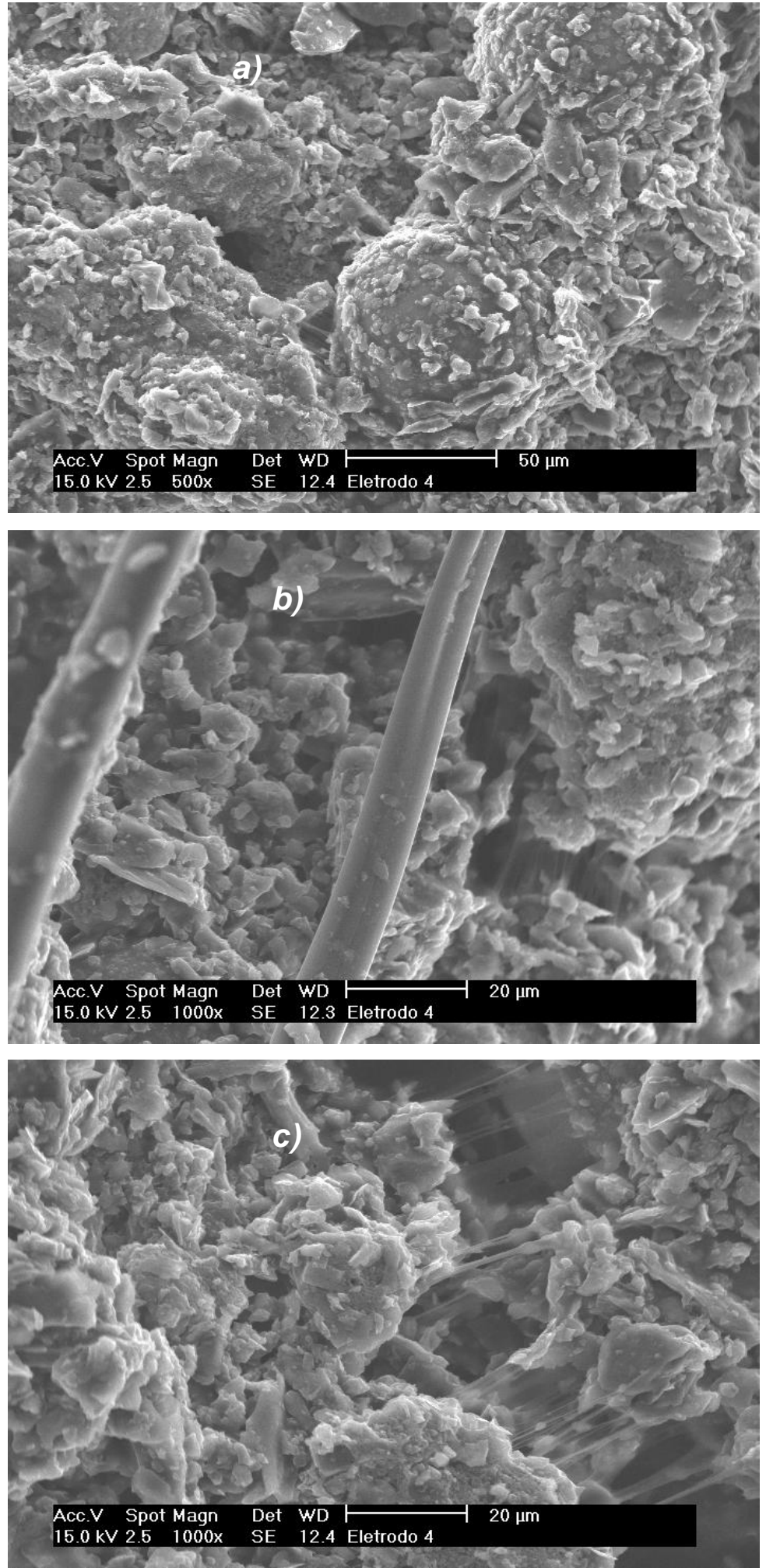

FIGURA 27 - Micrografias obtidas por Microscopia Eletrônica de Varredura (MEV) da superfície do ETI-4 com aumento de a) 500x, b) 1000x, c) $1000 x$. 


\subsubsection{Carbono Poroso}

\subsubsection{Condutância}

Na FIG.28 é mostrado o voltamograma cíclico do Carbono Poroso realizado em solução de $\mathrm{KNO}_{3}$ 0,1 mol. $\mathrm{L}^{-1}$ e velocidades de varredura de 0,2 a 2,0 mV.s ${ }^{-1}$. Verificou-se que a região da DCE está entre, 0,5 a 1,0V, que foi utilizada para o cálculo de $\mathrm{C}_{d} \mathrm{~S}$. A ampliação da DCE foi feita para uma melhor visualização da região.

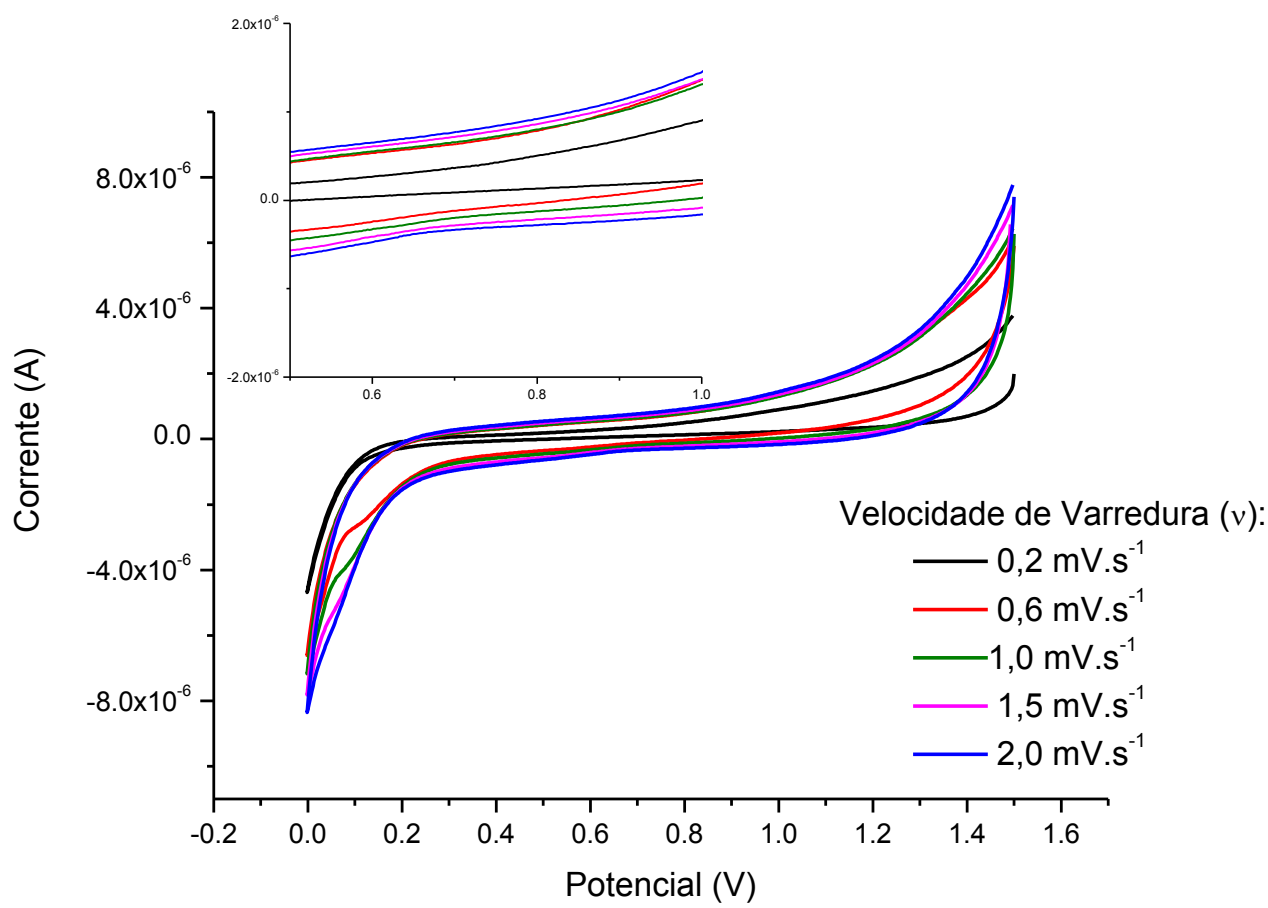

FIGURA 28 - Voltamograma cíclico do eletrodo de Carbono Poroso, em solução de $\mathrm{KNO}_{3}$ 0,1 mol.L ${ }^{-1}$, velocidade de varredura variando de 0,2 a 2,0 mV.s ${ }^{-1}$, com ampliação da região da DCE.

Na FIG.29 tem-se o gráfico da corrente estacionária $\left(i_{s}\right)$ em função da velocidade de varredura $(v)$ para os potenciais de 0,5, 0,6 e 0,7 V (vs $\mathrm{Ag} / \mathrm{AgCl}$ ) para o carbono poroso. O ajuste linear foi feito para cada curva, determinando desta forma $\mathrm{C}_{d} S$ (coeficiente angular da reta) para cada potencial segundo a Eq.13. 


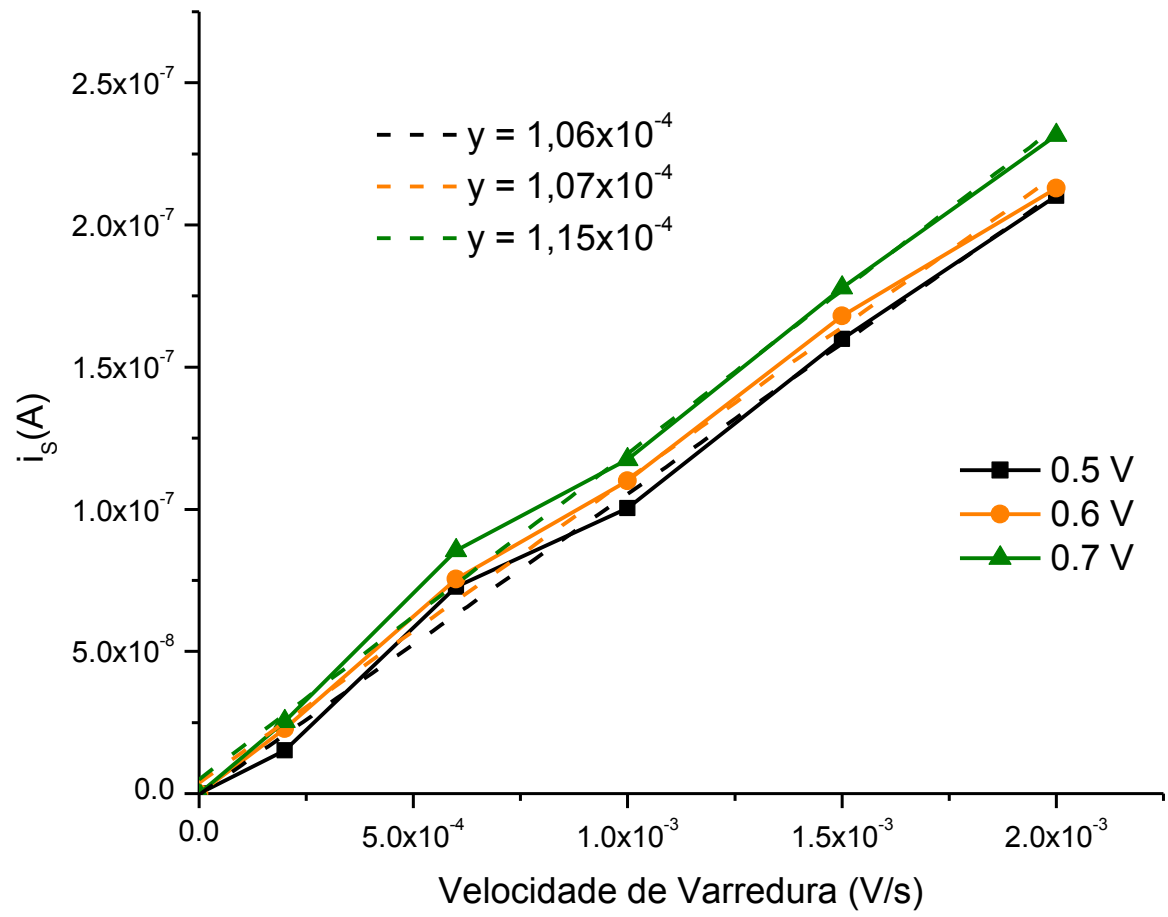

Figura 29 - Corrente capacitiva em função da velocidade de varredura para os potenciais de $0,5,0,6$ e $0,7 \mathrm{~V}$ (vs. $\mathrm{Ag} / \mathrm{AgCl}$ ) para o eletrodo de Carbono Poroso, com os respectivos ajustes segundo a Eq.13.

Na TAB.13 são mostrados os valores obtidos após o tratamento de dados (FIG.29) e os seus respectivos coeficientes de determinação, $R^{2}$.

TABELA 13 - Valores de $C_{d} S$ e do coeficiente de determinação para o eletrodo de Carbono Poroso.

\begin{tabular}{ccc}
\hline $\begin{array}{c}\text { Potencial } \\
(\mathrm{V})\end{array}$ & $\begin{array}{c}\mathrm{C}_{\mathrm{d}} \mathrm{S} \\
(\mathrm{F})\end{array}$ & $\begin{array}{c}\text { Coeficiente de } \\
\text { Determinação, } \mathrm{R}^{2}\end{array}$ \\
\hline 0,5 & $1,06 \times 10^{-4}$ & 0,9943 \\
\hline 0,6 & $1,07 \times 10^{-4}$ & 0,9958 \\
\hline 0,7 & $1,15 \times 10^{-4}$ & 0,9942 \\
\hline
\end{tabular}


$O$ valor médio encontrado $C_{d} S$ foi igual a $1,09 \times 10^{-4} \mathrm{~F}_{\mathrm{c}} \mathrm{cm}^{-2}$.

\subsubsection{Impedância}

Na FIG.30 está representado o diagrama de Bode para o eletrodo de Carbono Poroso realizado em solução eletrolítica de $\mathrm{KNO}_{3} \quad 0,1 \mathrm{~mol} . \mathrm{L}^{-1}$ para os potenciais de 0,5, 0,6 e 0,7 V (vs. Ag/AgCl).

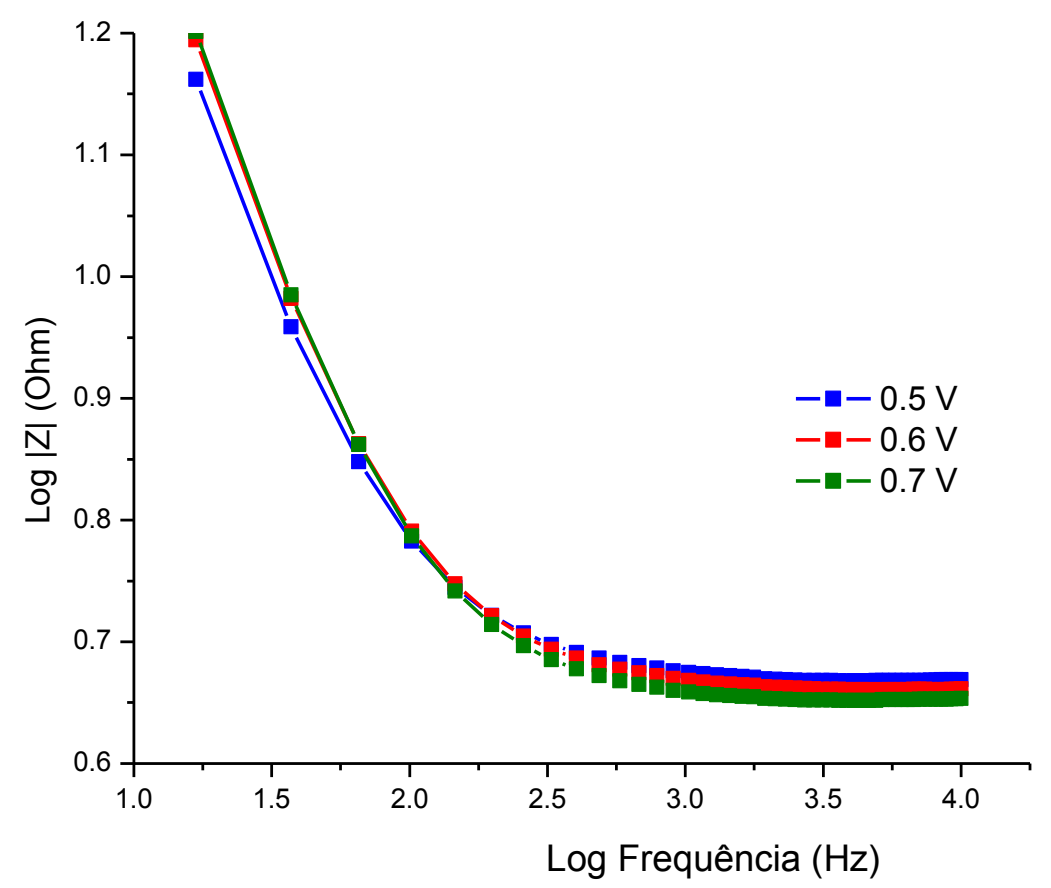

FIGURA 30 - Representação de Bode para o eletrodo de Carbono Poroso nos potenciais de 0,5, 0,6 e 0,7 V (vs. Ag/AgCl).

Realizou-se a extrapolação das curvas para a determinação de $|Z|$. Com este valor foi feito o inverso da função logarítmica e o seu valor foi substituído na Eq.15 para encontrar a capacitância, $\mathrm{C}_{\mathrm{d}}$, nos potenciais estudados. Finalmente calculou-se a média de $C_{d}$.

A TAB.14 mostra os valores do módulo da impedância e o valor da capacitância alcançado para os potenciais analisados. 
TABELA 14 - Valores do módulo da impedância e da capacitância para o eletrodo de Carbono Poroso.

\begin{tabular}{ccc}
\hline $\begin{array}{c}\text { Potencial } \\
(\mathrm{V})\end{array}$ & $\begin{array}{c}|\mathrm{Z}| \\
(\mathrm{ohm})\end{array}$ & $\begin{array}{c}\mathrm{C}_{\mathrm{d}} \\
\left(\mathrm{F} . \mathrm{cm}^{-2}\right)\end{array}$ \\
\hline 0,5 & $446,60 \times 10^{3}$ & $2,24 \times 10^{-6}$ \\
\hline 0,6 & $587,27 \times 10^{3}$ & $1,70 \times 10^{-6}$ \\
\hline 0,7 & $841,39 \times 10^{3}$ & $1,19 \times 10^{-6}$ \\
\hline O valor médio da capacitância foi igual a $1,71 \times 10^{-6} \mathrm{~F}_{\mathrm{cm}} \mathrm{cm}^{-2}$ para o
\end{tabular}

Carbono Poroso.

Fazendo os cálculos necessários e isolando $S$, obtém-se:

$$
\begin{gathered}
\bar{C}_{d} S=1,09 \times 10^{-4} \\
S=\frac{1,09 \times 10^{-4} \mathrm{~F}}{1,71 \times 10^{-6} \mathrm{Fcm}^{-2}} \\
S=63,7 \mathrm{~cm}^{2}
\end{gathered}
$$

Na FIG.31 são apresentadas micrografias representativas da superfície do eletrodo de Carbono Poroso, obtidas por MEV para o estudo da morfologia da amostra. Com o aumento da resolução (FIG.31(b) e (c)) é possível observar fases diferentes separadas por fronteiras que não são possíveis de se distinguir em menores ampliações (FIG.31 (a)). Este eletrodo foi obtido comercialmente e foi usado como recebido. 

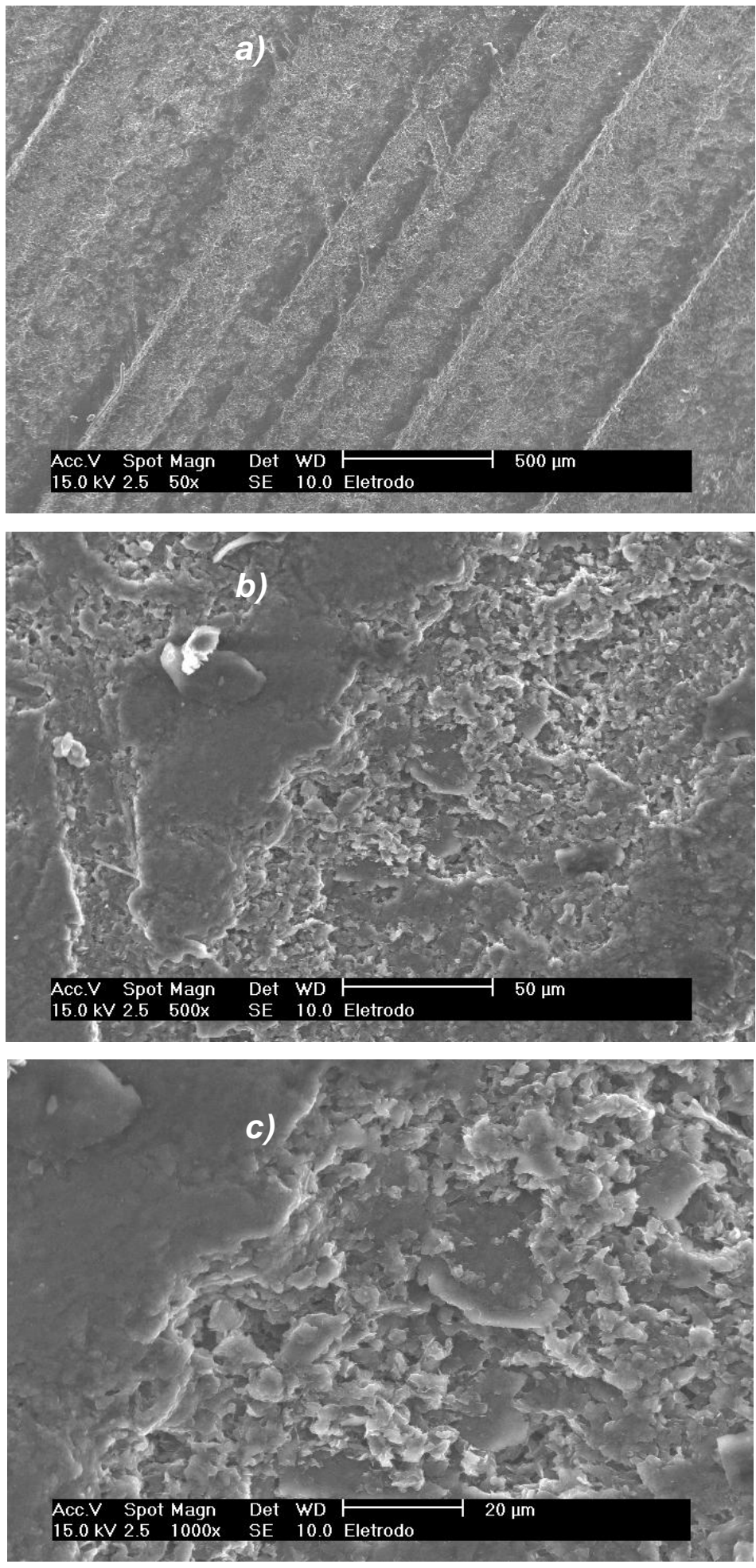

FIGURA 31 - Micrografias obtidas por Microscopia Eletrônica de Varredura (MEV) da superfície do Eletrodo de Carbono Poroso com aumento de: a) 50x, b) 500x e c) 1000x. 
Um espectro de impedância típico obtido na faixa de frequência de 10 $\mathrm{Hz}-10 \mathrm{KHz}$ para os eletrodos de carbono poroso, carbono vítreo, ETI-1, ETI-3 e ETI-4 a $25^{\circ} \mathrm{C}$ (Diagrama de Bode) é mostrado na FIG.32, que apresenta o logaritmo dos valores absolutos de Impedância, $|Z|$, e os valores absolutos do ângulo de fase $|\phi|$, como função do logaritmo da frequência.

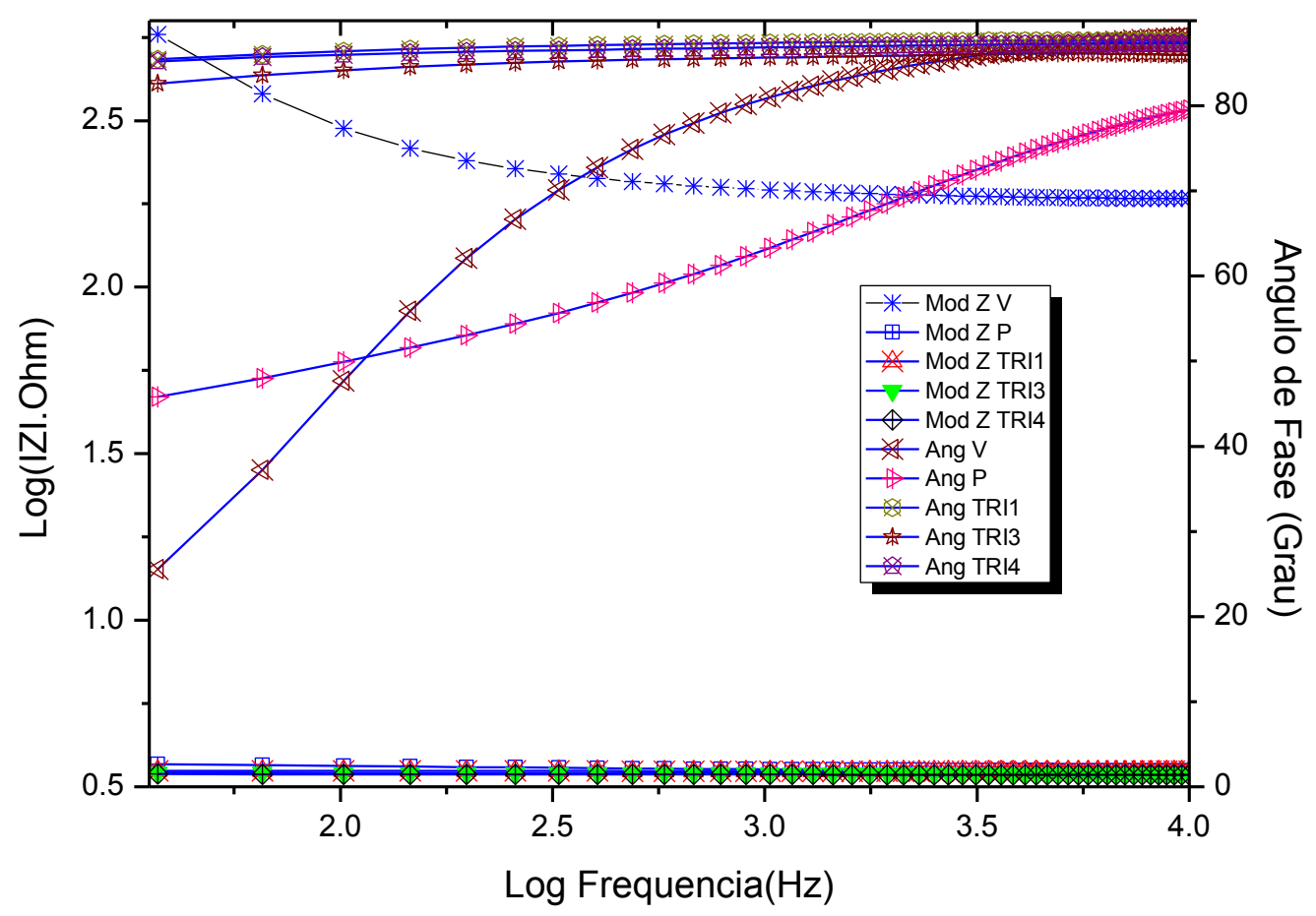

Figura 32 - Diagrama de Bode obtido na temperatura ambiente para as amostras dos eletrodos: Carbono Vítreo, Carbono Poroso, ETI1, ETI-3 e ETI-4.

Em baixas freqüências, os ângulos de fase se localizam a $20^{\circ}$, isto é: as amostras não atuam como resistores puros, enquanto que a altas freqüências atuam como capacitores. Dentro de uma determinada faixa de freqüências $\left(10^{2} \mathrm{e}\right.$ $10^{2,5} \mathrm{~Hz}$ ) para os eletrodos de Carbono Poroso, ETI-1, ETI-3 e ETI-4, a impedância é praticamente constante $\left(10^{0,5} \mathrm{ohm}\right)$. Esta faixa de freqüência é 
dominada por R. Os ângulos de fase atribuídos a estes mesmos eletrodos a altas freqüências são próximos a $90^{\circ}$, como dever-se-ia esperar para a situação de idealidade, entretanto para o eletrodo de Carbono Poroso o ângulo se aproxima de $80^{\circ}$, o que pode ser explicado por perdas dielétricas ${ }^{[46,47,49]}$.

Todos os eletrodos estudados, com exceção do eletrodo de Carbono Vítreo, apresentaram uma morfologia não-compacta e heterogênea com uma dispersão irregular do revestimento, conforme analisadas nas micrografias obtidas por MEV e confirmadas pelos resultados obtidos pelas análises de EIE.

A EIE oferece a possibilidade de avaliar e comparar a condutividade intrínseca dos eletrodos independente de sua composição, formato e método de preparação. O exame dos diagramas de Bode mostrados na FIG.32 indica que o comportamento das condutividades dos eletrodos é de natureza distinta, com predominância para o ETI-1, ETI-3 e ETI-4 que apresentam os valores mais baixos de impedância, mantendo-a praticamente constante até a faixa mais alta de frequência de $10^{2,5} \mathrm{~s}^{-1}$ a $10^{4} \mathrm{~s}^{-1}$. Esta faixa de freqüências é dominada por fenômenos que ocorrem na interface eletrodo/eletrólito, ou seja a cinética de reações de transferência eletródica ${ }^{[1,46,47,49]}$.

Fenômenos como a velocidade de reação não uniforme através dos poros, ou seja, a superfície exterior carrega-se ou descarrega-se numa taxa diferente da superfície interior, causam incertezas na determinação da superfície eletroquimicamente ativa por medidas de impedância ${ }^{[46,49,50]}$.

A TAB.15 mostra os valores de $\overline{C_{d} S}$ e de $C_{d}$ que foram obtidos pelos métodos de condutância e impedância, respectivamente, para os eletrodos estudados. 
TABELA 15 - Valores de capacitância para os eletrodos estudados por condutância e impedância.

\begin{tabular}{cccc}
\hline \multirow{2}{*}{ Método } & Eletrodo & $\begin{array}{c}\overline{C_{d} S} \\
(\mu F)\end{array}$ & $\begin{array}{c}C_{d} \\
\left(\mu F c^{-2}\right)\end{array}$ \\
\hline \multirow{2}{*}{ Condutância } & Carbono Vítreo & 13,16 & 419,2 \\
& Troca lônica 1 & $52 \times 10^{3}$ & \\
& Troca lônica 3 & $38 \times 10^{3}$ & \\
& Troca lônica 4 & $105 \times 10^{3}$ & \\
& Carbono Poroso & 109,1 & 172 \\
& Carbono Vítreo & 5,40 & $11 \times 10^{3}$ \\
& Troca lônica 1 & & $22 \times 10^{3}$ \\
& Troca lônica 3 & & $32 \times 10^{3}$ \\
& Troca lônica 4 & & 1,71 \\
\hline & Carbono Poroso & & \\
\hline
\end{tabular}

$\mathrm{Na}$ TAB.15 pode-se verificar que o alto valor de $C_{d}$ encontrado para o eletrodo de Carbono Vítreo está relacionado com a superfície polida do mesmo e esta em concordância com a literatura ${ }^{[1,55,56]}$.

Por outro lado o baixo valor de $C_{d}$ para o eletrodo de Carbono Poroso $\left(1,71 \mu \mathrm{F}_{\mathrm{cm}} \mathrm{cm}^{-2}\right)$ pode ser explicado por meio das alterações na taxa de crescimento do tamanho dos grãos, sugerindo que o controle dessas propriedades torna-se relevante ${ }^{[1,55,56]}$. Pode-se ainda acrescentar que a determinação da área superficial eletroquimicamente ativa através da EIE depende de vários fatores, entre estes os acima citados, fazendo com que o erro na área superficial seja considerável.

Os ETI-1, ETI-3 e ETI-4 mostram serem bons capacitores eletroquímicos $11 \times 10^{3}, 22 \times 10^{3} e 32 \times 10^{3} \mu \mathrm{F} . \mathrm{cm}^{-2}$, respectivamente, indicando 
grande área superficial (alta porosidade) como demonstram as micrografias apresentadas.

A TAB.16 mostra os valores da área geométrica e da área superficial ativa para cada eletrodo.

TABELA 16 - Valores de área geométrica e de área superficial ativa determinada pelos métodos eletroquímicos

\begin{tabular}{c|c|c}
\hline Eletrodo & Área Geométrica $\left(\mathrm{cm}^{2}\right)$ & $\mathrm{S}\left(\mathrm{cm}^{2}\right)$ \\
\hline ETI-1 & 1 & 4,72 \\
\hline ETI-3 & 1 & 1,73 \\
\hline ETI-4 & 1 & 3,28 \\
\hline Poroso & $2,83 \times 10^{-1}$ & 63,7 \\
\hline
\end{tabular}

Os valores de área superficial ativa, S, são maiores que a área geométrica, logo os materiais condutores contribuem significativamente na determinação da área ativa. Para os ETI o aumento do aglutinante na composição do eletrodo implicou no valor de área obtida, sendo que a menor área obtida foi do ETI-3 que apresentou maior quantidade de aglutinante em sua composição.

O uso combinado das técnicas de impedância e condutância mostra-se promissor para o cálculo de $C_{d}$ para o eletrodo de Carbono Vítreo e de Carbono Poroso. Entretanto para os demais eletrodos, maior atenção terá de ser dada à uniformidade da distribuição do revestimento sobre o substrato, conduzindo a uma superfície uniforme e com grãos pequenos, melhorando inclusive a resistência e durabilidade do conjunto revestimento/substrato tornando seu uso viável como removedor de metais tóxicos, além de outras aplicações. 


\subsection{BET}

Com o objetivo de comparação dos valores das áreas obtidos por condutância e impedância para o eletrodo de Carbono Poroso e para o ETI-1 com outro método já existente, foram realizadas medidas de BET.

\subsubsection{Eletrodo de Carbono Poroso}

A análise por BET do Carbono Poroso, para uma área geométrica de $1,531 \mathrm{~cm}^{2}$ e massa de $0,2769 \mathrm{~g}$, forneceu uma área superficial específica de $3,2519 \mathrm{~m}^{2} \cdot \mathrm{g}^{-1}$, que representa uma área superficial de $9,01 \times 10^{3} \mathrm{~cm}^{2}$. Este resultado acima do valor determinado pelo método eletroquímico, $63,7 \mathrm{~cm}^{2}$, explica-se pelo fato do eletrólito não ter acesso a superfície interna da estrutura do eletrodo de carbono poroso. Contudo, o método desenvolvido apresenta resultados coerentes, mas que requer estudos com outros materiais ${ }^{[1,55,56]}$.

\subsection{2 $\operatorname{ETI}-1\left(3,1 \mathrm{~cm}^{2}\right)$}

A análise por BET do ETI-1 para uma massa de 0,1412 g forneceu como resultado uma área especifica de $S=(23,2 \pm 0,4) \times 10^{4} \mathrm{~cm}^{2} \cdot \mathrm{g}^{-1}$, o que determina uma área superficial de $3,27 \times 10^{4} \mathrm{~cm}^{2}$. O valor da área encontrado por BET foi superior ao obtido pelos métodos eletroquímicos, $9,31 \mathrm{~cm}^{2}$. Por condutância e impedância apenas os materiais condutores contribuem na estimativa da área superficial ativa do eletrodo, o que não ocorre pelo método de BET, pois toda molécula de gás é adsorvida na superfície do eletrodo e contribuirá para a determinação da área superficial.

A TAB. 17 mostra os resultados encontrados pelos métodos BET e eletroquímicos, para o eletrodo poroso e o ETI-1. Nesta tabela pode-se verificar a diferença nos valores de área alcançados por cada método, indicando que a morfologia dos eletrodos e a quantidade de materiais condutores são fatores determinantes na estimativa da área pelo método eletroquímico. 
TABELA 17 - Valores de área superficial ativa dos eletrodos estudados pelos métodos de BET e eletroquímico.

\begin{tabular}{ccc}
\hline Método & Eletrodo & $\mathrm{S}\left(\mathrm{cm}^{2}\right)$ \\
\hline \multirow{2}{*}{ BET } & Carbono Poroso & $9,01 \times 10^{3}$ \\
& ETI-1 & $9,33 \times 10^{6}$ \\
\hline \multirow{2}{*}{ Eletroquímico } & Carbono Poroso & 63,7 \\
& ETI-1 $\left(1 \mathrm{~cm}^{2)}\right.$ & 4,72 \\
& ETI-1 $\left(3,1 \mathrm{~cm}^{2)}\right.$ & 9,31 \\
\hline
\end{tabular}

\section{CONCLUSÃO}

Neste trabalho, o uso combinado de duas técnicas eletroquímicas, voltametria cíclica e espectroscopia de impedância eletroquímica, permitiu a determinação da área superficial ativa de eletrodos modificados à base de carbono. Este método torna-se atrativo em relação aos métodos clássicos por ser simples e utilizar somente um reagente como eletrólito.

A determinação da área superficial é baseada no conhecimento da região da dupla camada elétrica. Inicialmente, foi determinado o valor da capacitância, $\mathrm{C}_{d}$, do carbono vítreo por voltametria cíclica e por espectroscopia de impedância eletroquímica, admitindo que a área superficial ativa era a sua área geométrica. Os valores de $\mathrm{C}_{\mathrm{d}}$ obtidos para o eletrodo de carbono vítreo foram $172 \mu \mathrm{Fcm}^{-2} \mathrm{e}$ $450 \mu \mathrm{Fcm}^{-2}$ para o método de Impedância e de Condutância, respectivamente. Como o valor determinado por impedância se aproxima ao valor encontrado na literatura para o carbono vítreo, adotou-se o cálculo de $\mathrm{C}_{\mathrm{d}}$ dos outros eletrodos à base de carbono por impedância. 
O cálculo de $C_{d}$ para os eletrodos de troca iônica requer maior atenção devido a não uniformidade da distribuição do revestimento sobre o substrato, ou seja, deve-se buscar maior uniformidade para melhorar inclusive a resistência e durabilidade do conjunto revestimento/substrato, tornando seu uso mais viável, como por exemplo, na remoção de metais tóxicos.

O exame dos diagramas de Bode mostrou que o comportamento da condutividade dos eletrodos é de natureza distinta, principalmente para os eletrodos de troca iônica ETI-1, ETI-3 e ETI-4, que apresentaram os valores mais baixos de impedância.

Os eletrodos ETI-1, ETI-3 e ETI-4 mostraram serem bons capacitores eletroquímicos, com $\mathrm{C}_{\mathrm{d}}$ igual a $11 \times 10^{3}, 22 \times 10^{3} \mathrm{e} 32 \times 10^{3} \mu \mathrm{F} . \mathrm{cm}^{-2}$ respectivamente, indicando grande área superficial.

A área superficial alcançada para os ETI-1, ETI-3, ETI-4 e para o eletrodo de carbono poroso pelos métodos eletroquímicos foram 4,72, 1,73, 3,28 e $63,7 \mathrm{~cm}^{2}$ respectivamente. Nota-se que para os eletrodos ETI a quantidade de materiais presentes em suas composições interferiu no valor de área obtido, ou seja, para o eletrodo que apresentou maior quantidade de aglutinante sua área foi à menor. Provavelmente este material impede a passagem de corrente e a formação de sítios ativos.

As micrografias foram analisadas para cada um dos eletrodos confeccionados e mostraram que as condições de processamento utilizadas levaram à obtenção de um material não uniforme, com falhas e uma mistura nãohomogênea dos componentes da formulação, diferentemente dos eletrodos de carbono vítreo e de carbono poroso.

Com o objetivo de verificar os valores das áreas obtidas para o carbono poroso e para o ETI-1, foram realizadas medidas de BET. Notou-se que o valor da área encontrado para o carbono poroso por BET $\left(9,01 \times 10^{3} \mathrm{~cm}^{2}\right)$ foi superior ao obtido pelos métodos eletroquímicos $\left(63,7 \mathrm{~cm}^{2}\right)$ provavelmente pelo fato do 
eletrólito não ter acesso a superfície interna da estrutura do eletrodo de carbono poroso. Para o ETI-1 o valor da área encontrado por BET $\left(9,33 \times 10^{3} \mathrm{~cm}^{2}\right)$ também foi superior $\left(9,33 \times 10^{3} \mathrm{~cm}^{2}\right)$ mostrando que no método eletroquímico $\left(9,31 \mathrm{~cm}^{2}\right)$ apenas os materiais condutores contribuem na estimativa da área superficial ativa do eletrodo. Pelo método de BET toda molécula de gás adsorvido no eletrodo contribuirá para a determinação da área superficial ativa.

A metodologia desenvolvida neste trabalho, diferentemente das outras técnicas, determina a área superficial eletroquimicamente ativa, podendo, desta forma, representar uma importante ferramenta na caracterização de eletrodos e na obtenção dos valores de densidade de corrente. 


\section{REFERÊNCIAS BIBLIOGRÁFICAS}

1. Calas-BLANCHARD, C.; COMTAT, M.; MARTY, J.L.; MAURAN, S. Textural characterization of graphite matrices using electrochemical methods. Carbon, v.41(1), p. 123-130, 2003.

2. BURKE A. Ultracapacitors: Why, how, and where is the technology. $J$ Power Sources, v. 91, p. 37-50, 2000.

3. FRACKOWIAK E, BÉGUIN F. Carbon materials for the electrochemical storage of energy in capacitors. Carbon, v. 39 (6), p. 937-950, 2001.

4. MANOSSO, H.C. Desenvolvimento de eletrodos de troca iônica eletroquímica para o tratamento de rejeitos contendo íons crômio ou césio. 2006. Tese (Doutorado) - Instituto de Pesquisa Energéticas e Nucleares, São Paulo.

5. MANOSSO, H.C.; FORBICINI, C.A.L.G. DE O. Treatment of wastes containing cesium bi electrochemical íon exchange (EIX). J. Radional. Nucl. Chem., v.279, p. 417-422, 2009.

6. OLIVEIRA NETO, A; WATANABE, A.Y.; RODRIGUES, R..S.; LINARDI, M.; FORBICINI, C.A.L.G. DE O.; SPINACÉ, E.V. Electrooxidation of ethanol using Ptrare earth- $\mathrm{C}$ electrocatalysts prepared by an alcohol reduction process. Ionics, v.14, p. 577-581, 2008.

7. SANTORO, T.A.B.; RIBEIRO, V.A.; FORBICINI, C.A.L.G de O.; OLIVEIRA NETO, A; SPINACÉ, E.V.; LINARDI, M. Preparação de eletrocatalisadores Ptla/C para estudos frente a reação de redução do oxigênio em célula do 
tipo PEMFC. In: XVIII CONGRESSO DE LA SOCIEDAD IBEROAMERICANA DE ELETROQUÍMICA, 2008, Medelin.

8. SANTORO, T.A.B.; RIBEIRO, V.A.; FORBICINI, C.A.L.G. de O.; OLIVEIRA NETO, A.; SPINACÉ, E.V.; LINARDI, M.; RODRIGUES,R.M.S.; PASTOR, E. Synthesis of PtLa/C catalyst for polymer electrolyte membrane fuel cells, In: I SIMPOSIUM IBÉRICO DE HIDROGÊNIO, PILAS DE COMBUSTIBLE Y BATERIAS AVANZADAS (HYCELTEC 2008), 2008, Espanha.

9. BRUNAUER, S.; EMMETT, P.H.; TELLER, E. Adsorption of gases in multimolecular layers. J. Am. Chem. Soc., v. 60, p. 309-319, 1938.

10.BARRETT, E.P.; JOYNER, L.G.; HALENDA, P.P. The volume and area distributions in porous substances. J. Am. Chem. Soc., v. 73, p. 373-380, 1951.

11.MOSCOU, L.; LUB, S. Practical use of mercury porosimetry in the study of porous solids. Powder Technol., v. 29 (1), p. 45-52, 1981.

12. VIDACKOVIC, T.; CHRISTOV, M.; SUNDMACGER, K. A method for rough estimation of the catalyst surface area in a fuel cell. J. Appl. Electrochem., v. 39 (2), p. 213-225, 2009.

13.VIDACKOVIC, T.; CHRISTOV, M.; SUNDMACHER, K. The use of CO stripping for in situ fuel cell catalyst characterization, v. 52 (18), p. 56065613, 2007.

14. OLIVES, R.; MAURAN, M. A highly conductive porous medium for solid-gas reactions: effects of the dispersed phase on the thermal tortuosity. Transp. Porous Media, v. 43, p. 377-394, 2001.

15.TREMBLAY, M.L.; MARTIN, M.H.; LEBOUIN, C.; LASIA, A.; GUAY, D. Determination of the real surface area of powdered materials in cavity 
microelectrodes by electrochemical impedance spectroscopy. Electrochlm. Acta, v.55 (21), p. 6283-6291, 2010.

16.BOTTON, J.C. Líquidos iônicos como eletrólitos para reações eletroquímicas. 2007. Tese (Doutorado) - Instituto de Química: Universidade Federal do Rio Grande do Sul, Porto Alegre.

17.WEHMWYER, K.R.; WIGHTMAN, R.M. Scan rate dependences of the apparent capacitance at microvoltammetric electrodes. J. Electroanal. Chem., v.196, p. 417-421, 1985.

18.FERTONANI, F.L.; BENEDETTI, A.V. Microeletrodos: Construção e caracterização. Eclet. Quím.; v. 22, p. 1-16, 1997.

19.LAZZARI, M.; MASTRAGOSTINO, M.; SOAVI, F. Capacitance response of carbons in solvent-free ionic liquids electrolytes. Electrochem. Commum., v. 9, p. 1567-1573, 2007.

20.JISHA, M.R.; HWANG, Y.J.; SHIN, J.S.; NAHM, K.S.; KUMAR, T.P.; KARTHIKEYAN, K.; DHANIKAIVELU, N.; KALPANA, D.; BENGAMATHAN, N.C.; STEPHAN, A.M. Electrochemical Characterization of supercapacitors based on carbons derived from coffee shells. Mat. Chem. Phys., v. 115, p. 33-39, 2009.

21.ZHENG, J.P.; PETIT, C.M.; COONETILLEKE, P.C.; ZENGER, C M.; ROY, D.D.C. Voltammetry of ionc liquid-based capacitors: Effects of Faradic reactions, electrolyte resistance and voltage sacn speed investigated using

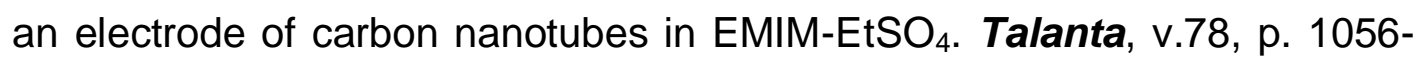
$1062,2009$.

22.BERGAMINI, M.F.; VITAL, S.I.; SANTOS, A.L.; STRADIOTTO, N.R. Determinação de chumbo em álcool combustível para voltametria de redissolução anódica utilizando um eletrodo de pasta de carbono 
modificados com resina de troca iônica Amberlite IR120. Eclética Química, v. 31, p. 44-52, 2006.

23.FUNGARO, D.A. Eletrodos modificados com polímeros perfluorado e sulfonados: aplicação em análise ambientais. Química Nova, v. 23, p. 805$811,2000$.

24.COSTA, M.I.C.F. Preparação e caracterização de eletrodos modificados mistos e sue uso em hidrogenação eletrocatalítica de substratos orgânicos. 2006. Tese (Doutorado) - Instituto de Química: Universidade de São Paulo, Ribeirão Preto.

25.JANEGITZ, B.C.; MARCOLINO, L.H; FATIBELLO-FILHO, O. Determinação voltamétrica por redissolução anódica de $\mathrm{Cu}(\mathrm{II})$ em águas residuárias empregando um eletrodo de pasta de carbono modificado com quitosana. Química Nova, v. 30, p. 1673-1676, 2007.

26.MURPHY, G.W.; ARNOLD, B.B. The electrochemistry of carbon and chemically-modified carbon surface. Electrochim. Acta, v.12 (2), p. 191204, 1967.

27.EVANS, S.; HAMILTON, W.S.; LEWIS, J.E. Electrochemically controlled cation exchange. Electrochem. Technol., v. 6, p.153-155, 1968.

28.EVANS, S.; HAMILTON, W.S.; The mechanism of demineralization at carbon eletrodes. J. Electrochem. Soc., v.113, p. 1314-1319, 1966.

29.NEVILLE, M.D.; JONES, C.P.; TURNER, A.D. The EIX process for radioactive waste treatment. Prog. Nucl. Energy, v. 32 (3-4), p. 397-401, 1998. 
30.ACCOMAZZO, M.A.; EVAN, S. Electrochemically controlled íon exchange II. Transpot processes. J. Electrochem. Soc.: Electrochem. Technol., v.116, p. 309-311, 1969.

31.FRANCO, E.G.; Desenvolvimento de Novos Eletrocatalisadores para células a combustível a membrana polimérica trocadora de prótons. 2005. Tese (Doutorado) - Instituto de Pesquisa Energéticas e Nucleares, São Paulo.

32.SILVA, D.F.; OLIVEIRA NETO, A.; PINO, E.S.; LINARDI, M.; SPINACÉ, E.V.; Preparação de Nanopartículas de Pt-Ru suportadas em Carbono (Eletrocatalisadores PtRu/C) utilizando feixe de elétrons. In: CONGRESSO BRASILEIRO DE ENGENHARIA E CIÊNCIA DOS MATERIAIS CBECIMat, 17², 2009, Foz do Iguaçú, PR.

33.STOECKLI, F.; CENTENO, T.A.; On the determination of surface areas in activated carbons. Carbon, v. 43 (6), p. 1184-1190, 2005.

34.SANTOS, W.J.R.; LIMA, P.R.; TANAKA, A.A.; TANAKA, S.M.C.N.; KUBOTA, L.T. Determination of nitrite in food samples by anodic voltammetry using a modified electrode. Food Chemistry, v. 113 (4), p. 1206-1211, 2009.

35.COUTRIN, N.P.; ALTENOR, S.; COSSEMENT, D.; MAURIS, C.J.; GASPARD, S. Comparison of parameters calculated from the BET and Freundlich isotherms obtained by nitrogen adsorption on activated carbons: A new method for calculating the specific surface area. Microporous and Mesoporous Materials, v. 111, p. 517-522, 2008.

36.SERPINET, J. Application of inverse gas chromatography, to the determination of the surface area of macroporous and mesoporous adsorbents. J. Chromatography, v. 119, p. 483-493, 1976. 
37.DOLLIMORE, D.; SPOONER, P.; TURNER, A. The BET method of analysis of gas adsorption data and its relevance to the calculation of surface areas. Surface Technol., v. 4 (2), p. 121-160, 1976.

38.MOURA, J.M.; FIGUEIREDO, M.M. Aplicação das Técnicas de Picnometria de gás e de Picnometria de Mercúrio à Caracterização da Madeira de E. Globulus. Silva Lusitana, v. 10, p. 207-216, 2002.

39.HELLOCO, J.G.; DURAND, R. A study of $\mathrm{RuO}_{2}$ as an electrocatalyst for hydrogen evolution in alkaline solution. J. Appl. Electrochem., v. 26, p. 397-402, 1996.

40.BURKE, L.D.; MURPHY, O.J. A study of $\mathrm{RuO}_{2}$ as an electrocatalyst for hydrogen evolution in alkaline solution. J. Appl. Electrochem., v. 39, p. 213-225, 2009.

41.SOFFER, A.; FOLMSN, M. The electrical double-layer of high surface porous carbon electrodes. J. Electroanal. Chem., v. 38 (1), p. 25-41, 1972.

42.GAGNON, E.G. The triangular voltage sweep method for determining double-layer capacity of porous electrodes - II. Porous silver in potassium hydroxide. J. Electrochem. Soc., v. 120, p. 1052-1056, 1973.

43.GAGNON, E.G. The triangular voltage sweep method for determining double-layer capacity of porous electrodes - III. Porous nickel in potassium hydroxide. J. Electrochem Soc., v. 121, p. 512-515, 1974.

44.OREN, Y.; TOBIAS, H.; SOFFER, A. The electrical double-layer of carbon and graphite electrodes - Parte I. Dependence on electrolyte type and concentration. J. Electroanal. Chem., v. 162, p. 87-99, 1984. 
45.WOLYNEC, S. Técnicas Eletroquímicas em Corrosão. Cap. 6 São Paulo: Editora da Universidade de São Paulo, 2003.

46.BONORA, P.L.; DEFLORIAN, F.; FEDRIZZI, L. Electrochemical impedance spectroscopy as a tool for investigating underpaint corrosion. Electrochimica Acta, v. 41 (7-8), p. 1073-1082, 1996.

47.JIANGUO, L.; GAOPING, G.; CHUANWEI, Y. EIS study of corrosion behavior of organic coating/ Dacromet composite systems. Electrochlm. Acta, v. 50 (16-17), p. 3320-3332, 2005.

48.BOGGIO, R.; CARUGATTI, S.; TRASATI, S. Electrochemical surface properties of $\mathrm{Co}_{3} \mathrm{O}_{4}$ electrodes. J. Appl. Electrochem., v. 17, p. 828-840, 1987.

49. TREMBLAY, M.L. ET AL. Determination of the real surface area of powdered materials in cavity microelectrodes by electrochemical impedance spectroscopy. Electrochlm. Acta, v. 55 (21), p. 6283 -6291, 2010.

50.ZHANG, J. ET AL. EIS-assisted performance analysis of non-noble metal electrocatalyst (Fe-N/C)- based PEM fuel cells in the temperature range of 23-80 C. Electrochlm. Acta, v. 54 (6), p. 1737-1743, 2009.

51.FERRARI, P.E. Obtenção e caracterização de carbono vítreo reticulado. 1996. Tese (Mestrado) - Instituto tecnológico da Aeronáutica, São José dos Campos.

52.DONNET, J.B.; EHRBURGER, P. Carbon fibre in polymer reinforcement. Carbon, v. 15, p. 143-152, 1977.

53.LIU, Y. ET AL. Amorphous carbon nanotubes produced by a temperature controlled DC are discharge. Carbon, v. 42, p.1852-1855, 2004. 
54.MARTIN, C.R.; Kohli, P. The emerging Field of nanotube biotecnology. Nat Rev. Drug Discover, v. 2, p. 29-37, 2003.

55.RAHMAN, M.M.; JEON, I.C. Studies of electrochemical behavior of SWNTfilm electrodes. J. Braz. Chem. Soc., v. 18, p. 561-756, 2007.

56.AZEVEDO, A.F.; FERREIRA, N.G. Filmes de nanodiamantes para aplicações em sistemas eletroquímicos e tecnologia aeroespacial. Química Nova, v. 29 (1), p. 129, 2006.

57.BRETT, A.M.O.; BRETT; C.M.A. Eletroquímica: Princípios, Métodos e Aplicações. Coimbra: Livraria Almeida, 444p., 1993. 